\title{
Synthesis and Pharmacological Evaluation of Triazolopyrimidinone Derivatives as Noncompetitive, Intracellular Antagonists for CC Chemokine Receptors 2 and 5
}

Natalia V. Ortiz Zacarías, Jacobus P. D. van Veldhoven, Lisa S. den Hollander, Burak Dogan, Joseph Openy, Ya-Yun Hsiao, Eelke B. Lenselink, Laura H. Heitman, and Adriaan P. IJzerman*(0)

Division of Drug Discovery and Safety, Leiden Academic Centre for Drug Research, Leiden University, P.O. Box 9502, 2300 RA Leiden, The Netherlands

Supporting Information

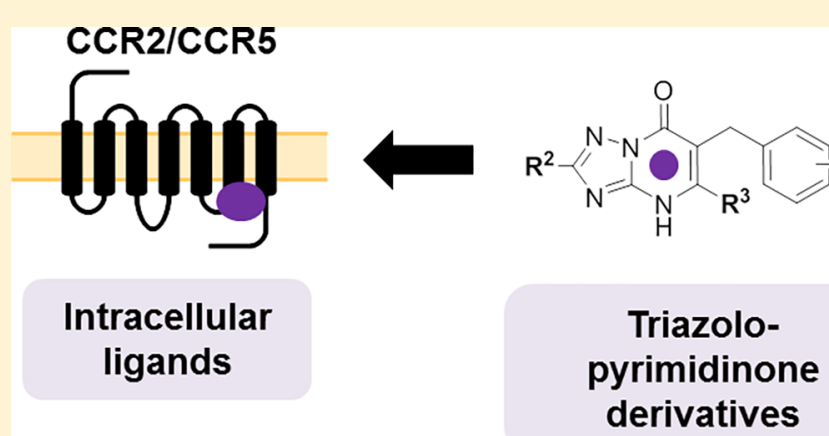

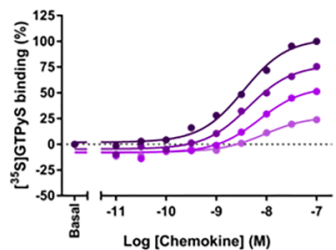

Insurmountable

ABSTRACT: CC chemokine receptors 2 (CCR2) and 5 (CCR5) are involved in many inflammatory diseases; however, most CCR2 and CCR5 clinical candidates have been unsuccessful. (Pre)clinical evidence suggests that dual CCR2/CCR5 inhibition might be more effective in the treatment of such multifactorial diseases. In this regard, the highly conserved intracellular binding site in chemokine receptors provides a new avenue for the design of multitarget ligands. In this study, we synthesized and evaluated the biological activity of a series of triazolopyrimidinone derivatives in CCR 2 and CCR5. Radioligand binding assays first showed that they bind to the intracellular site of CCR2, and in combination with functional assays on CCR5, we explored structure-affinity/activity relationships in both receptors. Although most compounds were CCR2-selective, 39 and 43 inhibited $\beta$-arrestin recruitment in CCR5 with high potency. Moreover, these compounds displayed an insurmountable mechanism of inhibition in both receptors, which holds promise for improved efficacy in inflammatory diseases.

\section{INTRODUCTION}

CC chemokine receptors 2 (CCR2) and 5 (CCR5) are two membrane-bound $\mathrm{G}$ protein-coupled receptors (GPCRs), which belong to the subfamily of chemokine receptors. Chemokine receptors are widely expressed in leukocytes, and thus, they regulate different homeostatic and inflammatory leukocyte functions upon interaction with their endogenous chemokines. ${ }^{1,2}$ In general, chemokine receptors interact with multiple endogenous chemokines, such as CCL2, CCL7, and CCL8 in the case of CCR2, and CCL3, CCL4, and CCL5 in the case of CCR5. ${ }^{1}$ Furthermore, most chemokines can interact with multiple chemokine receptors, allowing for a very complex and fine-tuned system. ${ }^{3,4}$ Dysregulation of this system has been linked to the development of several pathophysiological conditions. For example, both CCR2 and CCR5 have been implicated in many inflammatory and immune diseases such as rheumatoid arthritis, multiple sclerosis, atherosclerosis, diabetes mellitus, and psoriasis, ${ }^{5,6}$ rendering these proteins attractive targets for the pharmaceutical industry. As a result, many efforts have been made to bring CCR2 and CCR5 small-molecule antagonists into the clinic although with limited success. Only maraviroc, an HIV-1 entry inhibitor selectively targeting CCR5, has been approved by the FDA and EMA, ${ }^{7}$ while all other drug candidates have failed in clinical trials.

Recently, it has been suggested that the development of multitarget drugs (designed to interact with multiple receptors) represents a more effective approach in the treatment of complex multifactorial diseases. ${ }^{8,9}$ Thus, dual targeting of CCR2 and CCR5 emerges as a potentially more efficacious strategy in diseases where both receptors are involved. Indeed, combined CCR2/CCR5 inhibition has resulted in beneficial effects in several preclinical disease models and clinical studies, further supporting the use of dual antagonists. ${ }^{10-12}$ In this regard, several antagonists with dual CCR2/CCR5 activity have been reported in the past years, including the first dual antagonist TAK-779 and the clinical candidate cenicriviroc. ${ }^{13}$ All of these antagonists bind to the extracellular region of CCR2 and CCR5, in a site overlapping

Received: May 6, 2019

Published: November 19, 2019 
<smiles>CC(=O)OC1=C(C(C)=O)C(C2CCCCC2)N(c2ccc(Cl)cc2F)C1=O</smiles><smiles>Nc1nc2[nH]c3c(c(=O)n2n1)CC1CC31</smiles>

Compound 8<smiles>O=C(O)c1ccccc1Oc1ccc(Cl)cc1NS(=O)(=O)c1ccc(Cl)c(Cl)c1</smiles>

SD-24<smiles>CCC(c1ccc(F)c(F)c1)n1c(C(=O)OC)c(-c2ccno2)[nH]c1=S</smiles>

JNJ-27141491

Figure 1. Chemical structures of the orthosteric CCR2/CCR5 antagonist TAK-779 and the CCR2 intracellular ligands CCR2-RA-[R], SD-24, JNJ27141491 and the triazolopyrimidinone derivative 8. $\left[{ }^{3} \mathrm{H}\right]-\mathrm{CCR} 2-\mathrm{RA}-[R]$ was used in radioligand binding assays for CCR2.

Scheme 1. Synthesis Scheme of the Triazolopyrimidinone Derivatives $6-43^{a}$

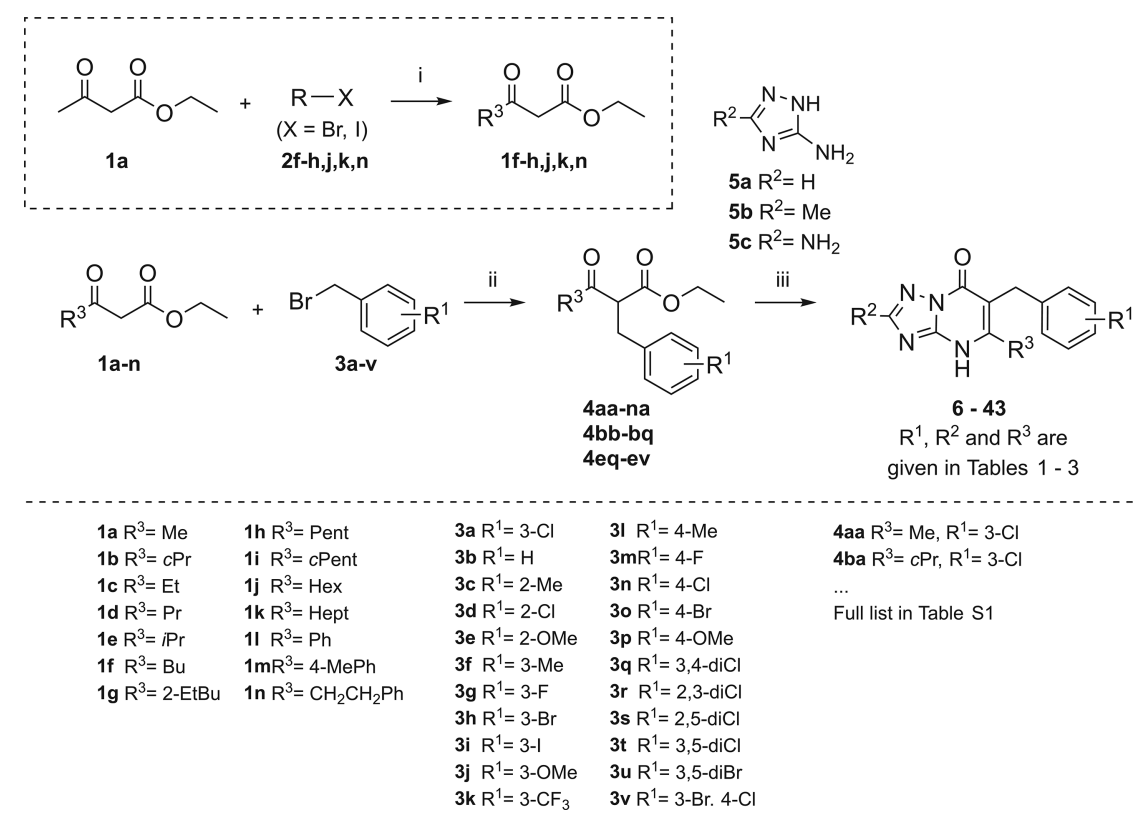

${ }^{a}$ Reagents and conditions: (i) NaH, $n$-BuLi, THF, overnight, $0{ }^{\circ} \mathrm{C}$ to rt (1a-e,i,l,m were commercially available); (ii) DIPEA, LiCl, THF, reflux, overnight; (iii) $\left(8-43, \mathrm{R}^{2}=\mathrm{NH}_{2}\right)$ BMIM-PF6, $200{ }^{\circ} \mathrm{C}, 1 \mathrm{~h}$ or $\left(6, \mathrm{R}^{2}=\mathrm{H}\right) \mathrm{H}_{3} \mathrm{PO}_{4}, \mathrm{EtOH}, 170{ }^{\circ} \mathrm{C}, 10 \mathrm{~h}$ or $\left(7, \mathrm{R}^{2}=\mathrm{Me}\right) p$-toluenesulfonic acid monohydrate, $180^{\circ} \mathrm{C}, 30 \mathrm{~min}$.

with the chemokine's binding pocket. ${ }^{14}$ Yet the crystal structures of CCR2 and CCR9 have demonstrated that chemokine receptors can also be targeted with intracellular allosteric modulators. ${ }^{15,16}$ These intracellular ligands offer a number of advantages, such as noncompetitive binding and, as a consequence, insurmountable inhibition, which is particularly important due to the high local concentration of chemokines during pathological conditions. ${ }^{17,18}$ In addition, the high conservation of this intracellular site allows for the design of multitarget antagonists. ${ }^{18,19}$ Several high-affinity intracellular ligands have been already identified for CCR2 $2^{20,21}$ but not for CCR5, although intracellular compounds developed for CCR2 or CCR4 have been reported to bind CCR5 with much lower potency. $^{21,22}$

In the current study we first report that previously patented CCR2 antagonists with a triazolopyrimidinone scaffold, such as compound 8 (Figure 1), ${ }^{23}$ bind to the intracellular site of the receptor with high affinity. In addition, we show that this compound is able to inhibit CCR5 with moderate activity, suggesting a potential dual CCR2/CCR5 activity for this class of compounds. Thus, a series of novel and previously reported triazolopyrimidinone derivatives were synthesized according to published methods ${ }^{23}$ in order to obtain structure-affinity/ activity relationships (SARs) in both CCR2 and CCR5. Radioligand binding assays and functional assays were used to evaluate their affinity toward CCR2 and activity toward CCR5. In addition, characterization of two selected compounds (39 and 43$)$ in a $\left[{ }^{35} \mathrm{~S}\right] \mathrm{GTP} \gamma \mathrm{S}$ binding assay demonstrated that these compounds inhibit both receptors in a noncompetitive, insurmountable manner. Finally, selected compounds were docked into the CCR2 crystal structure in order to shed light on the binding mode of these derivatives, in comparison to that of the crystallized CCR2-RA- $[R] .{ }^{15}$ In summary, our findings provide some insight on the CCR2/CCR5 selectivity profile of triazolopyrimidinone derivatives, as well as on the 
structural requirements for the design of multitarget or selective intracellular ligands for these receptors.

\section{RESULTS AND DISCUSSION}

Chemistry. Triazolo-pyrimidinone derivatives 6-43 were synthesized using a three-step synthesis approach as described by Bengtsson et al. ${ }^{23}$ (Scheme 1). First, if not commercially available, the $\beta$-keto esters $\mathbf{1 a}-\mathbf{n}$ were synthesized from ethyl acetoacetate $\mathbf{1 a}$ and the respective bromo- or iodoalkanes $\mathbf{2 f}-$ $\mathbf{h}, \mathbf{j}, \mathbf{k}$ or benzyl bromide $\mathbf{2 n}$. Benzylation of the $\beta$-keto esters $\mathbf{1 a}-\mathbf{n}$ with the corresponding $\mathrm{R}^{1}$-substituted benzyl bromides $(3 \mathbf{a}-\mathbf{v})$, at reflux, resulted in a series of benzylated $\beta$-keto esters $\mathbf{4 a a}-\mathbf{n a}, \mathbf{4 b b}-\mathbf{b q}, \mathbf{4 e q}-\mathbf{e v}$ in yields between $8 \%$ and $97 \%$ (Scheme 1, Table S1). Finally a cyclization reaction of the benzylated $\beta$-keto esters $4 \mathbf{a a}-\mathbf{n a}, \mathbf{4 b b}-\mathbf{b q}, \mathbf{4 e q}-\mathbf{e v}$ with the commercially available 3,5-diaminotriazole $\mathbf{5 c}$ in ionic liquid BMIM-PF6 (1-butyl-3-methylimidazolium hexafluorophosphate) at $200{ }^{\circ} \mathrm{C}$ under microwave irradiation resulted in final compounds $6,9-43$ in yields ranging from $4 \%$ to $83 \%$. Final compound $7\left(\mathrm{R}^{2}=\mathrm{H}\right)$ was synthesized using $\mathrm{H}_{3} \mathrm{PO}_{4}$ in ethanol conditions and $8\left(\mathrm{R}^{2}=\mathrm{Me}\right)$ in $p$-toluenesulfonic acid monohydrate conditions.

Biology. We have previously identified several CCR2 intracellular ligands belonging to different chemical scaffolds, such as CCR2-RA-[R], SD-24, and JNJ-27141491 (Figure $1) .^{20,21}$ In contrast to CCR2 orthosteric ligands, these intracellular ligands lack a basic nitrogen and have lower molecular weights, unsaturated systems with haloarenes, and acidic groups capable of forming hydrogen bonds. ${ }^{18,20}$ Other CCR2 antagonists with similar features have been described in the literature, including the triazolo- or pyrazolopyrimidinone derivatives described in two different patents. ${ }^{23,24}$ To test whether they also bind to the intracellular site of the receptor, we synthesized "example 1" from the patent by Bengtsson et al., ${ }^{23}$ corresponding to the triazolopyrimidinone derivative $\mathbf{8}$ in our study (Figure 1 ). Using a $\left[{ }^{3} \mathrm{H}\right]$-CCR2-RA- $[R]$ binding assay as previously described, ${ }^{19}$ we found that compound $\mathbf{8}$ fully displaced $\left[{ }^{3} \mathrm{H}\right]$-CCR2-RA- $[R]$ binding from U2OS cells stably expressing hCCR2b (U2OS-CCR2) with high affinity and a pseudo-Hill slope $\left(n_{\mathrm{H}}\right)$ close to unity, indicating a competitive interaction with $\left[{ }^{3} \mathrm{H}\right]-\mathrm{CCR} 2-\mathrm{RA}-[R]$ for the intracellular binding site. 8 displaced $\left[{ }^{3} \mathrm{H}\right]$-CCR2-RA- $[R]$ with a $\mathrm{p} K_{\mathrm{i}}$ of $8.90 \pm 0.04\left(K_{\mathrm{i}}=1.3 \mathrm{nM}\right.$, Figure $2 \mathrm{a}$ and Table 1), consistent with its previously reported activity in a CCR2 calcium flux assay $\left(\mathrm{IC}_{50}=16 \mathrm{nM}\right)$. $^{23}$

Previous studies have shown that some of these intracellular ligands are able to bind and inhibit multiple chemokine receptors, enabling the design of selective and multitarget inhibitors. ${ }^{19,21,22}$ In this regard, CCR5 is the closest homolog to CCR2, with $>90 \%$ sequence similarity of their intracellular binding pockets. From the main interactions of CCR2-RA- $[R]$ to CCR2, only Val244 ${ }^{6 \times 36}$ is exchanged to Leu236 $6^{6 \times 36}$ in $\mathrm{CCR5}^{15}$ (residues named according to structure-based Ballesteros-Weinstein nomenclature ${ }^{25}$ ). Thus, we investigated whether compound $\mathbf{8}$ is also able to inhibit the highly homologous CCR5. However, the much lower affinity of $\left[{ }^{3} \mathrm{H}\right]$ CCR2-RA- $[R]$ for CCR5 compared to CCR2 hindered us from performing radioligand binding assays. ${ }^{21}$ Thus, we assessed the CCR5 activity of $\mathbf{8}$ with a functional $\beta$-arrestin recruitment assay after stimulation with CCL3, one of the endogenous agonists of CCR5. For this assay, we also included the intracellular ligands CCR2-RA- $[R], S D-24$ and JNJ27141491, as well as the CCR2/CCR5 orthosteric antagonist a)

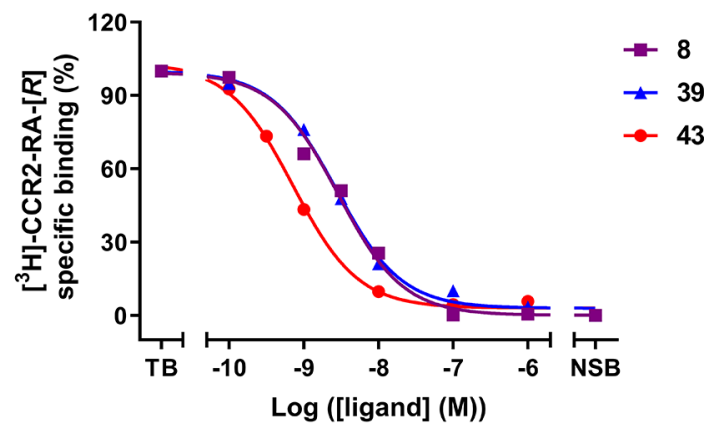

b)

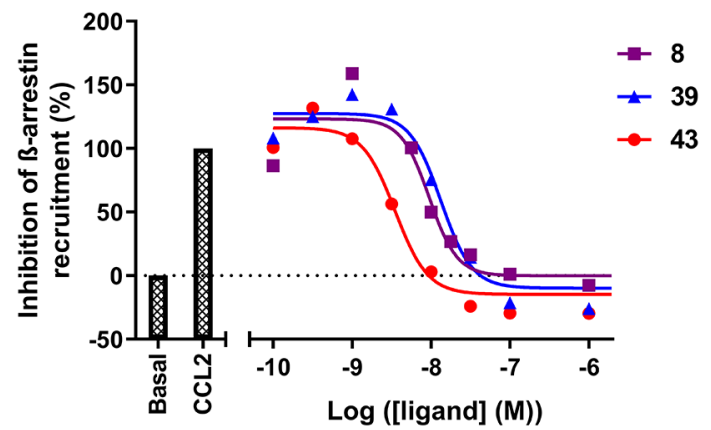

c)

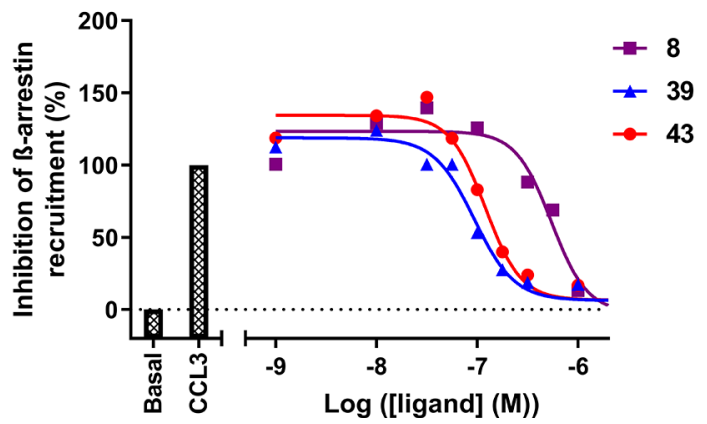

Figure 2. Characterization of ligands in U2OS-CCR2 and U2OSCCR5. (a) $\left[{ }^{3} \mathrm{H}\right]$-CCR2-RA- $[R]$ displacement by increasing concentrations of triazolopyrimidinone derivatives 8,39 , and 43 in U2OSCCR2 at $25{ }^{\circ} \mathrm{C}$. Data are normalized to specific binding in the absence of compound (set as 100\%). (b) Inhibition of CCL2stimulated $\beta$-arrestin recruitment in U2OS-CCR2 by increasing concentrations of compounds 8,39 , and 43 , after stimulation with an $\mathrm{EC}_{80}$ concentration of CCL2 (set as 100\%). (c) Inhibition of CCL3stimulated $\beta$-arrestin recruitment in U2OS-CCR5 by increasing concentrations of compounds 8,39 , and 43 , after stimulation with an $\mathrm{EC}_{80}$ concentration of CCL3 (set as 100\%). All data are from single, representative experiments performed in duplicate.

TAK-779 as a positive control (Figure 1), since it is a potent CCR5 antagonist in a variety of functional assays. ${ }^{26,27}$

In this assay, CCL3 induced $\beta$-arrestin recruitment to U2OS cells stably expressing hCCR5 (U2OS-CCR5) with a $\mathrm{pEC}_{50}$ of $8.3 \pm 0.08(6 \mathrm{nM})$ (Figure $\mathrm{S} 1 \mathrm{a})$, similar to values reported in the literature. ${ }^{28}$ As expected, TAK-779 was able to completely inhibit $\beta$-arrestin recruitment induced by an $\mathrm{EC}_{80}$ concentration of CCL3 $\left(\mathrm{pEC}_{80}=7.9 \pm 0.08\right)$, when tested at a single concentration of $1 \mu \mathrm{M}$ (Figure $\mathrm{S} 1 \mathrm{~b}$ ). In contrast, none of the intracellular ligands were able to fully inhibit CCL3-induced $\beta$ - 
Table 1. Characterization of Compounds 6-23 in hCCR2 and $\mathrm{hCCR5}^{a}$

$\begin{array}{lllll} & & & \\ & & & \end{array}$

${ }^{a}$ Data are presented as the mean $\mathrm{pK}_{\mathrm{i}} / \mathrm{pIC}_{50} \pm$ standard error of the mean (SEM) and mean $K_{\mathrm{i}} / \mathrm{IC}_{50}(\mathrm{nM})$ of at least three independent experiments performed in duplicate. ${ }^{b} \mathrm{p} K_{\mathrm{i}}$ values from the displacement of $\sim 6 \mathrm{nM}\left[{ }^{3} \mathrm{H}\right]$-CCR2-RA-[R] from U2OS cells stably expressing CCR2, at $25{ }^{\circ} \mathrm{C}$. ${ }^{c}$ Percent inhibition of $\beta$-arrestin recruitment in U2OS cells stably expressing CCR5 by $1 \mu \mathrm{M}$ compound, in the presence of CCL3 $\left(\mathrm{pEC}_{80}=7.9\right) \cdot \mathrm{pIC}_{50}$ values were determined for compounds displaying more than $70 \%$ inhibition. $\%$ Inhibition values are presented as means values of at least two independent experiments, performed in duplicate. ${ }^{d}$ No inhibition was observed at the concentration of $1 \mu \mathrm{M}$; instead some CCL3 stimulation was measured.

arrestin recruitment to the same level as TAK-779; in fact, only compound 8 displayed more than $70 \%$ inhibition when tested at $1 \mu \mathrm{M}$ (Figure S1b), while CCR2-RA- $[R]$, SD-24, and JNJ27141491 led to approximately $50 \%$ inhibition or less at the same concentration of $1 \mu \mathrm{M}$ (Figure S1b). Consistent with this low inhibition in CCR5, it was previously shown that CCR2RA-[R], JNJ-27141491, and SD-24 inhibited inositol phosphate (IP) formation in CCR5 with 7- to 22-fold lower potency compared to CCR2 inhibition. ${ }^{21}$ Preincubation of U2OS-CCR5 cells with increasing concentrations of TAK-779, before exposure to CCL3, resulted in an inhibitory potency $\left(\mathrm{IC}_{50}\right)$ of $6 \mathrm{nM}$, consistent with previously reported values (Table S2). ${ }^{27}$ Also in agreement with a previous study, ${ }^{21}$ the reference intracellular ligand CCR2-RA- $[R]$ inhibited CCL3induced $\beta$-arrestin recruitment with an $\mathrm{IC}_{50}$ value of $703 \mathrm{nM}$ (Table S2). Moreover, while TAK-779 inhibited CCL3induced $\beta$-arrestin recruitment with a pseudo-Hill slope close to unity $\left(n_{\mathrm{H}}=-1.1\right)$, CCR2-RA- $[R]$ inhibition showed a significantly higher Hill slope $\left(n_{\mathrm{H}}=-2.4\right)$, indicative of two different binding sites for CCL3 and CCR2-RA- $[R]$ (Table S2). ${ }^{29}$
As compound $\mathbf{8}$ was the best CCR5 inhibitor in this assay, displaying an $\mathrm{IC}_{50}$ value of $571 \mathrm{nM}$ and a Hill slope of $-2.2 \pm$ 0.3 (Figure $2 \mathrm{c}$ and Table 1 ), we then synthesized several triazolopyrimidinone derivatives to explore their structureaffinity/activity relationships (SARs) in CCR2 and CCR5. All synthesized triazolopyrimidinone derivatives were evaluated in $\left[{ }^{3} \mathrm{H}\right]$-CCR2-RA- $[R]$ binding assays to determine their binding affinity for CCR2 and in $\beta$-arrestin recruitment assays to determine their activity toward CCR5 (Figure 2 and Tables 1-3). In CCR5, compounds were first screened at a concentration of $1 \mu \mathrm{M}$, as we were only interested in dualtargeting compounds with moderate to high potencies $\left(\mathrm{IC}_{50}<\right.$ $1 \mu \mathrm{M})$. For the same reason, only those that displayed $>70 \%$ inhibition at this concentration were further evaluated in a concentration-inhibition curve to determine their potency. For better comparison, compounds 8, 39, and 43 were also tested in a CCR2 $\beta$-arrestin recruitment assay as previously described (Figure $2 \mathrm{~b}$ ). ${ }^{20}$ Finally, we determined the mechanism of inhibition of 39 and 43 in both CCR2 and CCR5 using a $\left[{ }^{35} \mathrm{~S}\right] \mathrm{GTP} \gamma \mathrm{S}$ binding assay (Figure 3, Table 4).

Structure-Affinity/Activity Relationships (SARs) in CCR2 and CCR5. Analysis of the triazolopyrimidinone derivatives started by modifying the amino group $\left(R^{2}\right)$ of the triazolo moiety $\left(\mathrm{R}^{2}\right.$, Table 1$)$. Compared to 8 , removing the amino group (6) resulted in a similar affinity toward CCR2, in agreement with the similar reported $\mathrm{IC}_{50}$ values of approximately $20 \mathrm{nM}$ for both compounds, when tested in a calcium flux assay. ${ }^{23}$ However, in CCR5 6 displayed a lower potency, as the inhibition of CCL3-stimulated recruitment of $\beta$-arrestin decreased to $60 \%$, compared to $76 \%$ inhibition by 8 . The introduction of a methyl group in $\mathrm{R}^{2}(7)$ was less favorable for both receptors, as both affinity for CCR2 and activity to CCR5 were reduced compared to $\mathbf{8}$. As compound $\mathbf{8}$ displayed the highest affinity/activity for both receptors, we decided to keep the amino group in $\mathrm{R}^{2}$ and explore different phenyl substituents ( $\mathrm{R}^{1}$, Table 1$)$, taking $\mathbf{8}$ as the starting point.

Compared to 8, the unsubstituted 9 showed a 5-fold decrease in affinity toward CCR2, while in CCR5 it was only able to inhibit $35 \%$ of the receptor response at $1 \mu \mathrm{M}$. Next, we investigated the effect of several benzyl modifications, including the influence of different substituent positions (Table 1). In the case of CCR2, meta-substituted derivatives yielded the highest affinities in this series of compounds (1318), whereas ortho-substituted derivatives yielded the lowest (10-12). None of the ortho-substitutions led to an improvement in affinity over $\mathbf{8}$ or the unsubstituted $\mathbf{9}$. Introduction of a methyl (10) or a chloro (11) group in this position resulted in affinities lower than $10 \mathrm{nM}$, while the introduction of an electron-donating methoxy group further reduced the affinity to $105 \mathrm{nM}(\mathbf{1 2})$, displaying the lowest CCR2 affinity in this series (Table 1). Moving the methyl group to meta (13) or para (19) position slightly improved the CCR2 binding affinity compared to 9, achieving the highest affinity in meta position (19, $3 \mathrm{nM})$. Similarly, moving the methoxy group to meta or para position resulted in improved affinities following the meta $>$ para > ortho order; however, the affinities remained lower than $10 \mathrm{nM}(17,13 \mathrm{nM} ; 23,21 \mathrm{nM})$, with no improvement over 9. This is consistent with functional data reported in the patent by Bengtsson et al., where similar compounds with a methoxybenzyl moiety displayed a loss of CCR2 activity compared to the unsubstituted-phenyl analogue. ${ }^{23}$ Substitution of the meta methoxy group by an electron-withdrawing $\mathrm{CF}_{3}$ 
a)

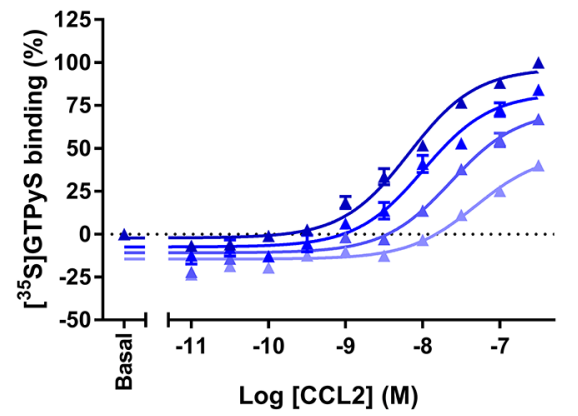

c)

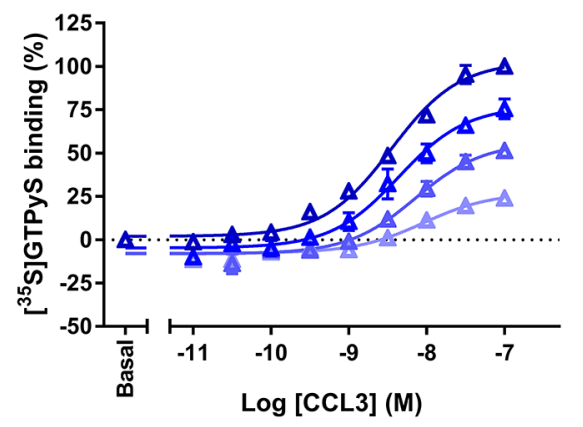

b)
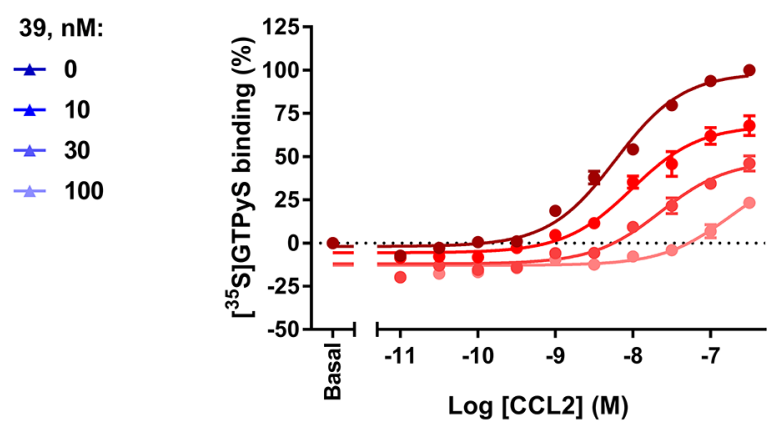

43, nM:

$\rightarrow 0$

$\rightarrow 1$

$-3$

$-10$

d)
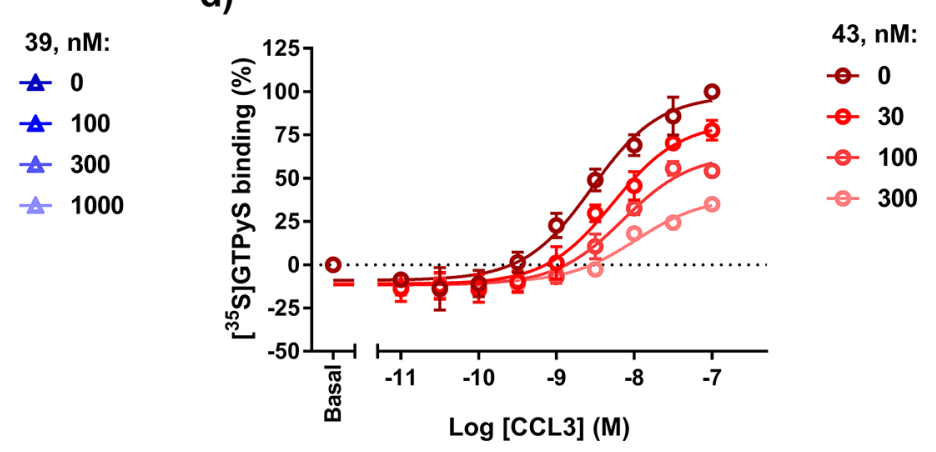

Figure 3. Characterization of compounds 39 and 43 as insurmountable, negative allosteric modulators using a $\left.{ }^{35} \mathrm{~S}\right] \mathrm{GTP} \gamma \mathrm{S}$ binding assay in hCCR2 and hCCR5. Effect of increasing concentrations of 39 and 43 in a CCL2-stimulated $\left.{ }^{35} \mathrm{~S}\right] \mathrm{GTP} \gamma \mathrm{S}$ binding in U2OS-CCR2 (a, b) or in a CCL3-stimulated $\left.{ }^{[35} \mathrm{S}\right] \mathrm{GTP} \gamma \mathrm{S}$ binding in U2OS-CCR5 $(\mathrm{c}, \mathrm{d})$, at $25^{\circ} \mathrm{C}$. Parameters obtained from the concentration-response curves $\left(\mathrm{pEC}_{50}\right.$, $\left.E_{\max }\right)$ are summarized in Table 4. Data are presented as mean \pm SEM values of three experiments performed in duplicate.

group resulted in improved affinity over $17(18,6 \mathrm{nM})$ but no improvement over the unsubstituted $\mathbf{9}$.

The effect of introducing different halogen groups was first investigated in the meta position. Overall, an increase in size and lipophilicity from fluoro to iodo resulted in improved binding affinities toward CCR2 $(\mathrm{F}, \mathbf{1 4}<\mathrm{Cl}, \mathbf{8}<\mathrm{Br}, \mathbf{1 5} \approx \mathrm{I}$, 16). In fact, compounds 15 and 16 displayed the highest affinities in this series of derivatives (15, $0.8 \mathrm{nM} ; 16,0.9 \mathrm{nM}$ ). Moving the halogen substituents to the para position resulted in a similar trend in affinity $(\mathrm{F}, \mathbf{2 0}<\mathrm{Cl}, \mathbf{2 1}<\mathrm{Br}, \mathbf{2 2})$; however, their affinities were lower compared to the meta-substituted analogues. Of note, compounds with a fluorine atom in meta (14) or para (20) position displayed lower affinities than compounds with a methyl group in the equivalent position (13 and 19). To gain more insight in a potential relationship between affinity and lipophilicity as observed in the halogen series, calculated $\log P$ values (cLogP) of compounds 8-23, with $\mathrm{R}^{1}$ modifications, were plotted against their $\mathrm{p} K_{\mathrm{i}}$ values in CCR2. This analysis revealed only a slight correlation between these two parameters for this set of compounds (Figure S2a); however, this correlation was lost when all synthesized derivatives were included in this plot (Figure S2b), indicating that this is not a general trend.

In the case of CCR5, meta-substituted derivatives also outperformed their ortho- and para-substituted analogues, with some compounds displaying $>60 \%$ inhibition at $1 \mu \mathrm{M}$; in contrast, ortho- and para-substitution resulted in compounds with low $(\leq 31 \%)$ to marginal efficacy in CCR5, suggesting that substituents in ortho or para position are not tolerated in CCR5. Similarly as in CCR2, the introduction of a methoxy group was unfavorable, as it led to a complete loss of activity in
CCR5 when tested at $1 \mu \mathrm{M}(12,17$, and 23), regardless of the position, whereas electron-withdrawing groups in meta position $\left(18, \mathrm{R}^{2}=\mathrm{CF}_{3}\right)$ did not bring any improvement over the unsubstituted 9. Except for compound $\mathbf{1 4}$ bearing a meta-fluoro, which showed less than $45 \%$ inhibition, all other compounds bearing halogens in meta position led to $>60 \%$ inhibition; the same was achieved when a methyl group was placed in this position (13). Overall, these data indicate that meta-substituents, especially halogens, are preferred to achieve dual CCR2/CCR5 activity, while ortho- and para-substituents lead to a lower affinity but higher selectivity toward CCR2.

As none of the other substituents in $\mathrm{R}^{2}$ led to a significant improvement in CCR5 activity over compound 8, we decided to continue with this compound and investigate the effect of replacing the cyclopropyl moiety in $\mathrm{R}^{3}$. On the basis of the chemical structure of $\mathbf{8}$ and CCR2-RA-[R] (Figure 1), we hypothesized that the cyclopropyl group in $\mathbf{8}$ interacts with Val244 ${ }^{6 \times 36}$ in CCR2 in a similar manner as the cyclohexyl group of CCR2-RA- $[R]{ }^{15}$ Thus, several triazolopyrimidinone derivatives were synthesized with different alkyl chains and aromatic groups in this position in order to investigate their SARs (Table 2). Starting with the effect of alkyl substituents, we observed that increasing the size and flexibility of the alkyl chain from $n=1$ (methyl) to $n=4$ (butyl) resulted in a parallel increase in CCR2 affinity $\left(17 \mathrm{nM}\right.$ for $\mathrm{R}^{3}=\mathrm{Me}(24) ; \sim \mathrm{nM}$ for $\mathrm{R}^{3}=\operatorname{Et}(25)$ and $\mathrm{R}^{3}=\operatorname{Pr}(26) ; 2 \mathrm{nM}$ for $\mathrm{R}^{3}=\mathrm{Bu}(28)$ ). However, further elongation of the chain length $(n=5-7)$ led to a progressive drop in affinity $\left(7 \mathrm{nM}\right.$ for $\mathrm{R}^{3}=$ Pent $(30) ; 22$ $\mathrm{nM}$ for $\mathrm{R}^{3}=\operatorname{Hex}(32) ; 178 \mathrm{nM}$ for $\left.\mathrm{R}^{3}=\operatorname{Hept}(\mathbf{2 8})\right)$, indicating that linear alkyl chains longer than five carbons might not fit in this hydrophobic pocket. The same trend was 
Table 2. Characterization of Compounds 24-36 in hCCR2 and $\mathrm{hCCR5}^{\mathrm{a}}$

$\begin{array}{llll} & & \\ & & \\ & & & \\ & & & \\ & & \end{array}$

${ }^{a}$ Data are presented as the mean $\mathrm{pK}_{\mathrm{i}} / \mathrm{pIC}_{50} \pm$ standard error of the mean (SEM) and mean $K_{\mathrm{i}} / \mathrm{IC}_{50}(\mathrm{nM})$ of at least three independent experiments performed in duplicate. ${ }^{b} K_{\mathrm{i}}$ values from the displacement of $\sim 6 \mathrm{nM}\left[{ }^{3} \mathrm{H}\right]$-CCR2-RA-[R] from U2OS cells stably expressing CCR2, at $25{ }^{\circ} \mathrm{C}$. ${ }^{c}$ Percent inhibition of $\beta$-arrestin recruitment in U2OS cells stably expressing CCR5 by $1 \mu \mathrm{M}$ compound, in the presence of CCL3 $\left(\mathrm{pEC}_{80}=7.9\right) \cdot \mathrm{pIC}_{50}$ values were determined for compounds displaying more than $70 \%$ inhibition. $\%$ Inhibition values are presented as mean values of at least two independent experiments, performed in duplicate. ${ }^{d}$ No inhibition was observed at the concentration of $1 \mu \mathrm{M}$; instead some CCL3 stimulation was measured.

observed for CCR5 activity, as only the $n$-propyl (26) and $n$ butyl (28) substituted compound led to $>60 \%$ inhibition, albeit without improvement over 8 (28, $519 \mathrm{nM})$. Moreover, introduction of a hexyl or heptyl group resulted in CCL3 stimulation instead of inhibition, which was not further investigated. Increasing bulkiness via branching of alkyl groups or substitution with aliphatic rings enhanced the affinity toward CCR2, indicating that these substituents might provide a better interaction with the receptor. For instance, the introduction of both isopropyl (27) and cyclopropyl (8) groups led to an improvement in CCR2 affinity compared to the linear analogue 26. Moreover, compound 27 with an isopropyl substituent also yielded a 2 -fold increase in CCR5 potency compared to the cyclic analogue 8 , displaying the highest potency in this series of compounds $(27,281 \mathrm{nM})$. In line with this trend, we observed that replacing the linear pentyl group (30) with a cyclopentyl group (31) was also beneficial for CCR2, as this derivative showed a 4.5 -fold increased affinity compared to $30(31,1.6 \mathrm{nM})$. In CCR5, 31 inhibited the CCL3-induced response with a potency of 388 $\mathrm{nM}$, showing a slight improvement over compound 8. In contrast, the introduction of a 2-ethylbutyl group (29) resulted in reduced affinity/activity toward both CCR2 and CCR5. These data suggest that the isopropyl group is the preferred $\mathrm{R}^{3}$ substituent when designing CCR2/CCR5 dual antagonists, as this substituent led to the highest potency in CCR5 while maintaining a high affinity for CCR2. Next, inspired by our work on CCR1/CCR2 selectivity of pyrrolone derivatives, ${ }^{19}$ we investigated whether aromatic substituents are tolerated in this position. As expected from previous studies, ${ }^{19,30}$ the introduction of aromatic groups decreased 20-fold (34, 27 $\mathrm{nM})$, 40-fold (36, $52 \mathrm{nM})$, and 122 -fold $(35,159 \mathrm{nM})$ the affinity for CCR2 compared to 8 . When tested in CCR5, all derivatives showed a complete loss of activity at $1 \mu \mathrm{M}$, indicating that aromatic groups are not favorable for selectivity or dual activity.

With the aim of finding dual CCR2/CCR5 intracellular inhibitors, we kept the isopropyl moiety in $\mathrm{R}^{3}$ and investigated the effect of having a disubstituted phenyl moiety in $\mathrm{R}^{1}$ by exploring different positions and combinations of chlorine and bromine atoms (Table 3). First and similar to 8 , we kept the

Table 3. Characterization of Compounds $37-43$ in hCCR2 and $\mathrm{hCCR5}^{\mathrm{a}}$

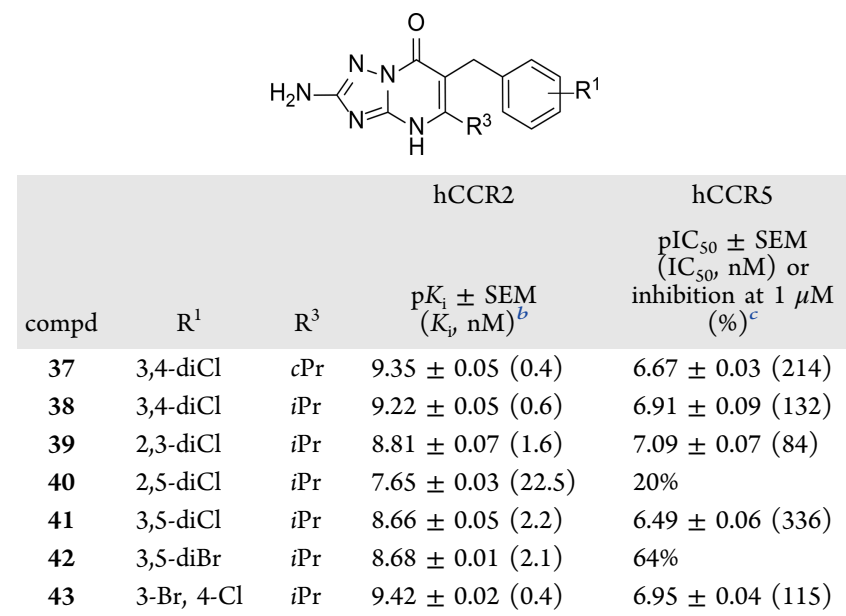

${ }^{a}$ Data are presented as mean $\mathrm{p} K_{\mathrm{i}} / \mathrm{pIC}_{50} \pm$ standard error of the mean (SEM) and mean $K_{\mathrm{i}} / \mathrm{IC}_{50}(\mathrm{nM})$ of at least three independent experiments performed in duplicate. ${ }^{b} \mathrm{p} K_{\mathrm{i}}$ values from the displacement of $\sim 6 \mathrm{nM}\left[{ }^{3} \mathrm{H}\right]$-CCR2-RA- $[R]$ from U2OS cells stably expressing CCR2, at $25{ }^{\circ} \mathrm{C}$. ${ }^{c}$ Percent inhibition of $\beta$-arrestin recruitment in U2OS cells stably expressing CCR5 by $1 \mu \mathrm{M}$ compound, in the presence of CCL3 $\left(\mathrm{pEC}_{80}=7.9\right)$. $\mathrm{pIC}_{50}$ values were determined for compounds displaying more than $70 \%$ inhibition. $\%$ Inhibition values are presented as mean values of at least two independent experiments, performed in duplicate.

cyclopropyl moiety in $\mathrm{R}^{3}$ and combined it with dichlorination in meta and para positions (37). Compared to the monosubstituted analogues $\mathbf{8}$ and $\mathbf{2 1}$, this compound yielded an even higher affinity to CCR2 $(37,0.4 \mathrm{nM})$; moreover, its ability to inhibit CCL3-induced response in CCR5 was also improved, as the potency increased to $214 \mathrm{nM}$. By replacing the cyclopropyl of 37 with an isopropyl group (38), we retained affinity for CCR2 $(0.6 \mathrm{nM})$, but the potency for CCR5 increased by almost 2-fold (132 nM), in agreement with the higher potency observed in $\mathbf{2 7}$ versus $\mathbf{8}$ (Table 2). Moving one chlorine atom to the ortho position, while keeping one in the adjacent meta position, yielded compound 39 with slightly lower affinity for CCR2 but even higher potency in CCR5 (39, $84 \mathrm{nM}$ ), indicating that although ortho substituents are not preferred in monosubstituted derivatives, they are still tolerated when placed in combination with halogens in other positions. However, placing the two halogens in the second and fifth positions was clearly detrimental for both receptors (40); in CCR2, the affinity decreased by almost 40-fold, while 
in CCR2, the compound was only able to inhibit $20 \%$ of the CCR5 response. Placing the two halogens in the symmetrical third and fifth positions restored the affinity/activity in both receptors (41, $2.2 \mathrm{nM}$ in CCR2 and $336 \mathrm{nM}$ in CCR5). Replacing the two chlorine atoms of 41 by bromine atoms yielded derivative $\mathbf{4 2}$, which retained affinity toward CCR2 but led to decrease in CCR5 activity, as this compound was not able to inhibit $>70 \%$ of the CCL3-induced response. Finally, the combination of a bromo in meta position with a chloro in para position (42) improved both the affinity and activity to both receptors to similar levels as 37 , in the case of CCR2, and 38 in the case of CCR5, indicating that halogens in adjacent positions are more favorable for activity in these receptors. Of note, compounds $\mathbf{3 7}, \mathbf{3 8}$, and 43 displayed the highest affinities to CCR2 in this study, while 38,39 , and 43 displayed the highest potencies to CCR5.

It is important to note that so far we are comparing data not only between two different receptors but also between two different assays: (i) a radioligand binding assay for CCR2, in the absence of agonist, which allows the determination of true affinities ( $\mathrm{p} K_{\mathrm{i}}$ values); (ii) a functional assay for CCR5 in the presence of an $\mathrm{EC}_{80}$ concentration of CCL3, without further correction of their $\mathrm{IC}_{50}$ values. To better compare the activities in both receptors, we selected starting compound $\mathbf{8}$ as well as compounds 39 and 43 (with the highest potency on CCR5 and the highest affinity for CCR2, respectively) and tested these in a previously described $\beta$-arrestin recruitment assay for CCR2. ${ }^{20}$ In this assay, compound $\mathbf{8}$ inhibited CCL2-stimulated $\beta$-arrestin recruitment with a potency of $10 \mathrm{nM}$ and a Hill slope of -2.7 , in agreement with its allosteric binding mode. Compound 39 inhibited $\beta$-arrestin recruitment in CCR2 with a lower potency of $21 \mathrm{nM}$, while compound 43 displayed a higher potency of $4 \mathrm{nM}$, consistent with their affinities. In addition, their Hill slopes $\left(n_{\mathrm{H}}=-2.5\right.$ for $39 ; n_{\mathrm{H}}=-3.4$ for 43$)$ are also indicative of a noncompetitive form of inhibition, a further confirmation of their allosteric binding site located in the intracellular region of CCR2 (Figure $2 b$ and Table S3). Of note, the Hill slopes in CCR5 were comparable to those in $\operatorname{CCR} 2\left(n_{\mathrm{H}}=-3.7\right.$ for $39 ; n_{\mathrm{H}}=-4.4$ for 43$)$, i.e., indicating an allosteric interaction at CCR5 as well. Comparing the $\mathrm{IC}_{50}$ values obtained with the functional assays in both receptors, we observe a 4-fold difference between CCR2 and CCR5 in the case of 39, making it a potential dual-antagonist for both receptors. In contrast, the potencies in CCR2 and CCR5 differ by 29 -fold in the case of $\mathbf{4 3}$, indicating a higher selectivity toward CCR2. Yet, network studies have suggested that partial inhibition by a low-affinity binder might be sufficient to effectively modulate cellular pathways in vivo; ${ }^{31}$ thus further studies are needed to establish the optimal activity ratio for these receptors in order to achieve in vivo efficacy. ${ }^{32}$

Mechanism of Inhibition of Selected Compounds. Selected compounds 39 and 43 were also tested in a $\left[{ }^{35} \mathrm{~S}\right] \mathrm{GTP} \gamma \mathrm{S}$ binding assay in both CCR2 and CCR5 in order to determine their mechanism of inhibition. In the case of CCR2, we have shown that these ligands fully displace $\left[{ }^{3} \mathrm{H}\right]$ CCR2-RA- $[R]$, indicating that triazolopyrimidinone derivatives bind in the same intracellular binding site. Thus, these compounds were expected to show noncompetitive, insurmountable antagonism to (orthosteric) chemokine ligands, as previously demonstrated in CCR2 with CCR2-RA- $[R]^{20}$ and JNJ-27141491. ${ }^{33}$ To verify this, 39 and 43 were characterized in a previously described $\left.{ }^{35} \mathrm{~S}\right] \mathrm{GTP} \gamma \mathrm{S}$ binding assay on U2OSCCR2 membranes. ${ }^{20}$ In this assay, CCL2-stimulation of $\left[{ }^{35} \mathrm{~S}\right] \mathrm{GTP} \gamma \mathrm{S}$ binding in CCR2 was examined in the absence or presence of fixed concentrations of $\mathbf{3 9}$ and $\mathbf{4 3}$ (Table 4 and

Table 4. Effects of Compounds 39 and 43 in ChemokineStimulated $\left[{ }^{35} \mathrm{~S}\right] \mathrm{GTP} \gamma \mathrm{S}$ Binding ${ }^{a}$

\begin{tabular}{|c|c|c|c|}
\hline receptor & compd & $\mathrm{pEC}_{50} \pm \underset{\mathrm{nM})}{\mathrm{SEM}}\left(\mathrm{EC}_{50}\right.$ & $E_{\max } \underset{(\%)^{b}}{ \pm}$ SEM \\
\hline \multirow[t]{7}{*}{ hCCR2 } & CCL2 & $8.10 \pm 0.06(8)$ & $107 \pm 2$ \\
\hline & $\mathrm{CCL} 2+10 \mathrm{nM} 39$ & $7.89 \pm 0.04(13)$ & $91 \pm 1^{* *}$ \\
\hline & $\mathrm{CCL} 2+30$ nM 39 & $7.60 \pm 0.07(26)^{* *}$ & $75 \pm 4 * * * *$ \\
\hline & $\begin{array}{l}\mathrm{CCL} 2 \\
\mathbf{3 9}\end{array}$ & $7.27 \pm 0.10(56)^{* * * *}$ & $50 \pm 3^{* * * *}$ \\
\hline & CCL2 + 1 nM 43 & $7.91 \pm 0.10(13)$ & $72 \pm 4 * * * *$ \\
\hline & CCL2 + 3 nM 43 & $7.53 \pm 0.12(32) * * *$ & $51 \pm 5^{* * * * *}$ \\
\hline & $\mathrm{CCL} 2+10 \mathrm{nM} 43$ & $6.87 \pm 0.13(148) * * * *$ & $33 \pm 3 * * * *$ \\
\hline \multirow[t]{7}{*}{ hCCR5 } & CCL3 & $8.42 \pm 0.06(4)$ & $108 \pm 2$ \\
\hline & $\begin{array}{l}\text { CCL3 } 39 \\
39\end{array}$ & $8.35 \pm 0.09(5)$ & $79 \pm 5^{* * * *}$ \\
\hline & $\begin{array}{l}\text { CCL3 } 3 \\
39\end{array}$ & $8.14 \pm 0.12(8)$ & $56 \pm 2 * * * *$ \\
\hline & $\begin{array}{l}\mathrm{CCL} 3 \\
39\end{array}$ & $8.14 \pm 0.17(9)$ & $25 \pm 4^{* * * * *}$ \\
\hline & $\mathrm{CCL} 3+30 \mathrm{nM} 43$ & $8.30 \pm 0.05(5)$ & $81 \pm 3 * * * *$ \\
\hline & $\begin{array}{l}\mathrm{CCL} 3 \\
\mathbf{4 3}\end{array}$ & $8.21 \pm 0.05(6)$ & $58 \pm 1 * * * *$ \\
\hline & $\begin{array}{l}\mathrm{CCL} 3 \\
\mathbf{4 3}\end{array}$ & $8.05 \pm 0.06(9) *$ & $35 \pm 2 * * * *$ \\
\hline
\end{tabular}

${ }^{a}$ Data represent the mean \pm standard error of the mean (SEM) of three independent experiments performed in duplicate. One-way ANOVA with Dunnett's post hoc test was used to analyze differences in $\mathrm{pEC}_{50}$ and $E_{\max }$ values against CCL2 or CCL3 controls. ${ }^{b}$ Maximum effect $\left(E_{\max }\right)$ of CCL2 or CCL3 measured in the absence or presence of fixed concentrations of compound 39 and 43 in CCR2 or CCR5, respectively.

Figure $3 a, b)$. In the absence of antagonist, increasing concentrations of CCL2 induced $\left[{ }^{35} \mathrm{~S}\right] \mathrm{GTP} \gamma \mathrm{S}$ binding with an $\mathrm{EC}_{50}$ of $8 \mathrm{nM}$, in line with previously described parameters. ${ }^{19,20}$ Co-incubation of CCL2 with 39 or 43 caused a significant reduction in the maximal response of CCL2 $\left(E_{\max }\right)$ at all three antagonist concentrations tested. The lowest concentrations of antagonist did not affect the potency of CCL2, while higher concentrations significantly reduced the potency of CCL2 (Table 4 and Figure 3a,b). Of note, both compounds were also tested in the absence of CCL2 at a single concentration of $1 \mu \mathrm{M}$ to determine potential inverse agonism. At this concentration they only reduced the basal $\left[{ }^{35} \mathrm{~S}\right] \mathrm{GTP} \gamma \mathrm{S}$ binding levels by $7-8 \%$ (Figure S3), providing too small a window to accurately determine their potencies as inverse agonists. Previously, we reported that some intracellular pyrrolone derivatives were also able to decrease the CCR2 basal activity in this assay; however, the effect seemed to be dependent on the assay conditions, such as GDP concentrations. ${ }^{19}$ Thus, more studies are needed to investigate whether the observed CCR2 constitutive activity is biologically relevant.

To confirm our hypothesis that these two compounds also bind to an allosteric site in CCR5, i.e., the intracellular binding site, we next analyzed the effect of 39 and 43 on CCL3induced $\left[{ }^{35} \mathrm{~S}\right] \mathrm{GTP} \gamma \mathrm{S}$ binding in U2OS-CCR5 membranes. In agreement with previous studies, CCL3 stimulated $\left.{ }^{35} \mathrm{~S}\right] \mathrm{GTP} \gamma \mathrm{S}$ binding in CCR5 with a potency of $4 \mathrm{nM}^{28}$ Similarly as in CCR2, the two compounds were able to significantly suppress the maximal response induced by CCL3 
at all concentrations tested (Table 4 and Figure $3 \mathrm{c}, \mathrm{d}$ ). However, in contrast to CCR2, the potency of CCL3 was only significantly reduced with the highest concentration of $\mathbf{4 3}$ (Table 4). Such depression of the maximal response with or without a decrease of agonist potency is typical of insurmountable antagonists, ${ }^{34}$ indicating that 39 and 43 behave as insurmountable antagonists at both CCR2 and CCR5. Of note, insurmountable antagonism can be generally achieved by two different mechanisms: allosteric binding or slow binding kinetics, i.e., slow equilibration of a competitive antagonist. $^{34}$ However, insurmountable inhibition due to hemiequilibrium is only evident in preincubation experiments, where the receptor is preincubated with the antagonist before exposure to the agonist. ${ }^{34}$ In contrast, allosteric binding leads to insurmountable inhibition in co-incubation experiments, as performed in this study. These data further support our hypothesis that $\mathbf{3 9}$ and $\mathbf{4 3}$ bind to an allosteric binding site in CCR5, most probably located intracellularly.

Docking Study. To further investigate the binding mode of triazolopyrimidinone derivatives, compounds $8,39,40$, and 43 were docked into a CCR2b model based on the crystal structure of CCR2 (PDB code 5T1A, Figures 4 and S4). ${ }^{15}$ Due to the close proximity to the intracellular binding site, several residues from the intracellular loop 3 (ICL3) had to be modeled based on the crystal structure of CCR5 (PDB code $4 \mathrm{MBS}){ }^{35}$ since they were mutated in the original CCR2 crystal structure to further stabilize the receptor. As seen in Figure 4a, 43 was predicted to adopt a similar binding pose as that of the previously cocrystallized ligand CCR2-RA- $[R] .^{15}$ The disubstituted phenyl group of $\mathbf{4 3}$ was constrained to overlap with the corresponding phenyl group of CCR2-RA$[R]$, since the disubstituted aromatic rings of JNJ-27141491 and SD-24 (Figure 1) were also predicted to overlay with the phenyl group of CCR2-RA- $[R]$ in a previous study. ${ }^{21}$ However, the bromine group of compound 43 is predicted to form a halogen bond with the backbone of $\mathrm{Val}^{1 \times 53}$, which might contribute to the higher affinity of $\mathbf{4 3}$ versus CCR2-RA$[R]$ (Figure $4 \mathrm{~b}$ ). The positions of the halogens in this phenyl group might also explain the results of our SAR study. For instance, compound $\mathbf{4 0}$ with no halogen group on position 3 is not able to form halogen bonds with the receptor; in addition, one of the chlorine groups seems to point upward toward $\mathrm{Tyr}^{7 \times 53}$, resulting in a sterically unfavorable position and thus in the observed lower activity (Figure S4 and Table 3). Similar to 43 , both 8 and 39 contain a chlorine group in position 3 , promoting the formation of a halogen bond with the backbone of $\mathrm{Val}^{1 \times 53}$, which might result in the improved activity compared to 40 (Figure S4 and Table 3). However, bromine displays a larger $\sigma$-hole and therefore a higher halogen bond strength compared to chlorine, ${ }^{36}$ which might result in the higher affinity of 43 , containing a bromine group, compared to 8 or 39 containing a chlorine. As the SAR follows a similar trend in CCR5, these data suggest that the intracellular ligands share similar interactions between the aromatic group and both receptors (Table 3 ).

In addition, the isopropyl group present in compounds 39, 40, and 43 is predicted to bind in the same position as the cyclohexyl moiety of CCR2-RA- $[R]$, although it seems to make less interactions with $\mathrm{Val}^{6 \times 36}$ perhaps due to the slightly different ligand orientation (Figure 4b). Previous studies have confirmed the crucial role of $\mathrm{Val}^{6 \times 36}$ for binding affinity of some intracellular ligands in CCR2, as mutation of this residue to alanine completely abolished binding of CCR2-RA- $[R]$ to
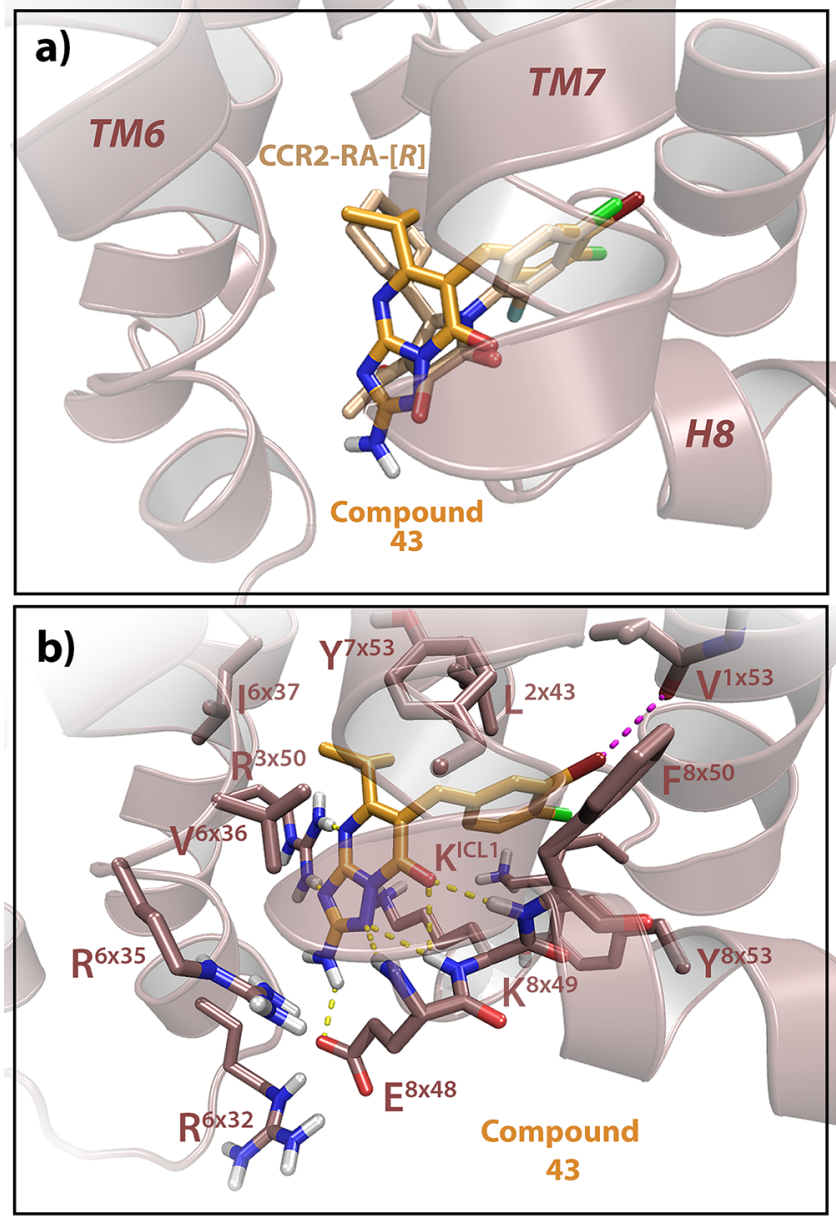

Figure 4. Proposed binding mode of 43 in hCCR2b. (a) Overlay of 43 with the CCR2 intracellular ligand CCR2-RA- $[R]$, showing that 43 interacts in a similar manner as CCR2-RA- $[R]$. (b) Docking of 43, displaying the interactions with CCR2. The amino group in $\mathrm{R}^{2}$ makes an extra hydrogen-bond interaction with $\mathrm{E}^{8 \times 48}$, while the bromine group in $\mathrm{R}^{1}$ makes an extra halogen bond with the backbone of $\mathrm{V}^{1 \times 53}$, which might contribute to the improved affinity of $\mathbf{4 3}$ to this receptor. Model of hCCR2 is based on the crystal structure of CCR2 (PDB code 5 T 1A), ${ }^{15}$ and amino acid residues are labeled according to their structure-based Ballesteros-Weinstein numbers. ${ }^{25}$

the receptor. ${ }^{21}$ Moreover, this residue might be involved in target selectivity, as the main difference between the intracellular pockets of CCR2 and CCR5 is the single substitution of $\mathrm{Val}^{6 \times 36}$ by $\mathrm{Leu}^{6 \times 36}$. The steric hindrance introduced by this substitution might thus be responsible for the reduction in activity of CCR2-RA- $[R]$ and the triazolopyrimidinone derivatives toward CCR5 compared to CCR2. ${ }^{21}$ Indeed, in the case of CCR5, only small aliphatic groups were tolerated in $\mathrm{R}^{3}$ position, such as cyclopropyl or isopropyl (Table 2), while bigger aliphatic groups resulted in improved selectivity toward CCR2. In line with the role of $\mathrm{Val}^{6 \times 36}$ as determinant of selectivity, a previous SAR analysis of pyrrolone derivatives in CCR1, which also contains a leucine in position $6 \times 36$, showed that aromatic groups in the equivalent $\mathrm{R}^{3}$ position provide CCR1 selectivity versus CCR2, as aromatic groups are not tolerated in this position in CCR2 ${ }^{19}$ (Table 2).

The binding pose of $\mathbf{4 3}$ seems to be stabilized by a network of hydrogen bonds between the triazolopyrimidinone core and residues $\mathrm{E}^{8 \times 48}, \mathrm{Lys}^{8 \times 49}, \mathrm{~F}^{8 \times 50}$, and $\mathrm{R}^{3 \times 50}$ (Figure $4 \mathrm{~b}$ ). Although the core of CCR2-RA- $[R]$ and 43 binds with a different 
orientation, the carboxy group of both is overlaid in the same position, interacting with the backbones of $\mathrm{Lys}^{8 \times 49}$ and $\mathrm{F}^{8 \times 50}$. Moreover, the secondary and tertiary amino groups present in the triazolopyrimidinone core also form hydrogen bonds with the backbones of $\mathrm{Lys}^{8 \times 49}$ and $\mathrm{Glu}^{8 \times 48}$, as well as with the side chains of $\operatorname{Arg}^{3 \times 50}$. Finally, the primary amino group in position $\mathrm{R}^{2}$ of compound $\mathbf{4 3}$ also makes an extra hydrogen bond with the side chain of $E^{8 \times 48}$. Such extended network of hydrogen bond interactions is not present with CCR2-RA- $[R]$, and thus it might also be responsible for the higher affinity of 43 in CCR2, compared to CCR2-RA- $[R]$. In addition, the SAR data suggest that this interaction is also crucial in CCR5, as the removal of this amino group (compounds 6 and 7) was detrimental for CCR5 activity (Table 1 ). Previous studies have confirmed the importance of residues $8 \times 49$ and/or $8 \times 50$ in chemokine receptors for the binding of several intracellular ligands. For example, alanine mutations of $\mathrm{Lys}^{8 \times 49}$ and $\mathrm{F}^{8 \times 50}$ in CCR2 caused a 10 -fold reduction or a complete loss of affinity of intracellular ligands, respectively, compared to the wild-type receptor. $^{21}$ In CXCR2, alanine mutation of Lys ${ }^{8 \times 49}$ led to a reduced affinity of three different intracellular ligands, while the mutation $\mathrm{F}^{8 \times 50} \mathrm{~A}$ only affected one of the ligands tested, indicating a different binding mode. ${ }^{37}$ Moreover, Lys ${ }^{8 \times 49}$ has been suggested as a key residue for target selectivity between CXCR1 and CXCR2, as it is exchanged by $\mathrm{Asn}^{8 \times 49}$ in CXCR1. ${ }^{38}$ In addition, the crystal structure of CCR9 in complex with vercirnon ${ }^{16}$ also shows a binding interaction between the ligand and $\operatorname{Arg} 323^{8 \times 49}$ and Phe $324^{8 \times 50}$.

Overall, these data suggest that although the intracellular pockets of CCR2 and CCR5 are quite conserved, the design of multitarget compounds is not quite straightforward. Moreover, several of these residues have been shown to be involved in $\mathrm{G} \alpha_{\mathrm{i}}$ coupling in recent cryoelectron microscopy (cryo-EM)derived GPCR structures, including residues $3 \times 50,6 \times 29,6$ $\times 32$ to $6 \times 37,8 \times 47$, and $8 \times 49 .{ }^{39-41}$ Similarly, homologous residues are also involved in direct interactions between rhodopsin and arrestin, ${ }^{42}$ suggesting a direct interference of these intracellular ligands with the $\mathrm{G} \alpha_{\mathrm{i}}$ protein and $\beta$-arrestin binding site, and the possibility of fine-tuning residue interactions for the design of biased ligands. On the basis of the SAR analysis and the docking study, these compounds could be further optimized by exploring the triazolopyrimidinone core. For instance, pyrazolopyrimidinones have also been described for CCR2, ${ }^{24}$ which might also display CCR5 activity. In addition, exploring other halogen combinations at the phenyl group in $\mathrm{R}^{1}$ or other small, bulky aliphatic groups in $\mathrm{R}^{3}$ such as cyclobutyl might lead to compounds with improved dual activity. Although out of the scope of this manuscript, ligands such as $\mathbf{3 9}$ with high potency in CCR5 could be investigated as potential tools to further study binding interactions in CCR5, i.e., by obtaining a radiolabeled tool compound or by obtaining a CCR5 crystal structure in complex with an intracellular ligand. Finally, these ligands can be used in future experiments designed to investigate their functional effects both in vitro and in vivo, to validate the target combination, and to establish the required level of target modulation. ${ }^{43}$

\section{CONCLUSIONS}

In this study we first confirmed that the triazolopyrimidinone derivative 8 binds to the intracellular pocket of CCR2 in a similar manner as the reference intracellular ligand CCR2-RA$[R]$. Moreover, compound $\mathbf{8}$ was also able to inhibit CCR5 in a functional $\beta$-arrestin recruitment assay; thus, we took this compound as a starting point for the synthesis of a series of novel and previously described triazolopyrimidinone derivatives. Using $\left[{ }^{3} \mathrm{H}\right]$-CCR2-RA- $[R]$ binding assays and functional $\beta$-arrestin recruitment assays, we explored structure-affinity/ activity relationships (SARs) in both receptors. Overall, these compounds were mostly selective toward CCR2; however, CCR5 activity was increased with the combination of a primary amino group in $\mathrm{R}^{2}$ position, an isopropyl moiety in $\mathrm{R}^{3}$, and two halogens placed in adjacent positions at the phenyl group in $\mathrm{R}^{1}$. Overall, these findings indicate that even though the intracellular pockets of CCR2 and CCR5 are highly conserved, selectivity of intracellular ligands can be fine-tuned, allowing the design of either selective or multitarget ligands. Evaluation of compounds 39 and 43 in a $\left[{ }^{35} S\right] \mathrm{GTP} \gamma S$ binding assay indicates that both compounds display a noncompetitive, insurmountable mode of inhibition in CCR2 and CCR5, which might represent a therapeutic advantage in inflammatory diseases characterized by a high local concentration of endogenous chemokines, such as multiple sclerosis and rheumatoid arthritis. Thus, in diseases where selective chemokine receptor antagonists have been largely unsuccessful, the development of multitarget, intracellular ligands for CCR2 and CCR5 is warranted to further study the effects of multitarget versus selective inhibition, as these ligands may represent a novel therapeutic option in these diseases.

\section{EXPERIMENTAL SECTION}

Chemistry. General Methods. All solvents and reagents used were of analytical grade and from commercial sources. Demineralized water was used in all cases, unless stated otherwise, and is simply referred to as $\mathrm{H}_{2} \mathrm{O}$. Microwave-based synthesis was carried out using a Biotage Initiator equipment (Biotage, Sweden). All reactions were monitored by thin-layer chromatography (TLC) using aluminum plates coated with silica gel $60 \mathrm{~F}_{254}$ (Merck), and compounds were visualized under ultraviolet light at $254 \mathrm{~nm}$ or via $\mathrm{KMnO}_{4}$ staining. Column chromatography for compound purification was performed using silica gel (Merck Millipore) with particle size 0.04-0.63 mm. Chemical identity of final compounds was established using ${ }^{1} \mathrm{H}$ NMR and liquid chromatography-mass spectrometry (LC-MS). ${ }^{1} \mathrm{H}$ NMR spectra were recorded on a Bruker AV 400 liquid spectrometer $\left({ }^{1} \mathrm{H}\right.$ $\mathrm{NMR}, 400 \mathrm{MHz}$ ) at room temperature. Compound 39, as one of the most soluble and one of the best CCR 2 /CCR5 antagonists, was fully characterized $\left({ }^{1} \mathrm{H}\right.$ NMR, ${ }^{13} \mathrm{C}$ NMR, and attached proton test (APT) on a Bruker AV500 spectrometer at $80{ }^{\circ} \mathrm{C}$. The corresponding NMR spectra of compound 39 are shown in Figures S5-S7. Chemical shifts $(\delta)$ are reported in parts per million (ppm), and coupling constants $(J)$ in Hz. Liquid chromatography-mass spectrometry (LC-MS) of final compounds was performed using a Thermo Finnigan Surveyor LCQ Advantage Max LC-MS system and a Gemini C18 Phenomenex column $(50 \mathrm{~mm} \times 4.6 \mathrm{~mm}, 3 \mu \mathrm{m})$. Analytical purity of the compounds was determined using a Shimadzu high pressure liquid chromatography (HPLC) equipment with a Phenomenex Gemini column ( 3 x C18 110A column, $50 \mathrm{~mm} \times 4.6 \mathrm{~mm}, 3 \mu \mathrm{m})$. A flow rate of $1.3 \mathrm{~mL} / \mathrm{min}$ and an elution gradient of $10-90 \% \mathrm{MeCN} /$ $\mathrm{H}_{2} \mathrm{O}$ ( $0.1 \%$ TFA) were used. The absorbance of the UV spectrophotometer was set at $254 \mathrm{~nm}$. All compounds tested in biological assays showed a single peak at the designated retention time and were $\geq 95 \%$ pure. Sample preparations for HPLC and LC-MS were as follows unless stated otherwise: $0.3 \mathrm{mg} / \mathrm{mL}$ of compound was dissolved in a 1:1:1 mixture of $\mathrm{H}_{2} \mathrm{O}: \mathrm{MeOH}:{ }^{t} \mathrm{BuOH}$. Of note, some compounds required DMSO and heat to ensure proper dissolution. None of the final compounds were identified as potential pan-assay interference compounds (PAINS) after assessment with the free ADME-Tox filtering tool (FAF-Drugs4), ${ }^{44,45}$ which uses three different PAINS filters based on Baell et al. ${ }^{46}$ 
General Procedure 1: Synthesis of $\beta$-Keto Esters 1f$\mathbf{h}, \mathbf{j}, \mathbf{k}, \mathbf{n} .{ }^{47}$ In a flame-dried round-bottom flask under a nitrogen atmosphere, ethyl acetoacetate $(2.53 \mathrm{~mL}, 20.0 \mathrm{mmol}, 1.00$ equiv) was added dropwise to a suspension of $\mathrm{NaH}(880 \mathrm{mg}, 22.1 \mathrm{mmol} 1.10$ equiv) in dry THF $(5 \mathrm{~mL})$ at $0{ }^{\circ} \mathrm{C}$ while stirring. After $20 \mathrm{~min}, n$ butyllithium (20 $0.0 \mathrm{mmol}, 2.50 \mathrm{M}$ solution in pentane, 1.00 equiv) was added dropwise to the mixture and stirred for further $30 \mathrm{~min}$. The respective alkyl halide $\mathbf{2} \mathbf{f}-\mathbf{h}, \mathbf{j}, \mathbf{k}$ or benzyl bromide $\mathbf{2 n}$ (1.20 equiv) was subsequently added dropwise over a period of $10 \mathrm{~min}$ to the dianion solution after which the solution was allowed to reach rt. After $14 \mathrm{~h}$, the reaction was quenched by the addition of saturated $\mathrm{NH}_{4} \mathrm{Cl}$ (aq, $80 \mathrm{~mL}$ ). The mixture was subsequently extracted with diethyl ether $(2 \times 120 \mathrm{~mL})$. The combined organic fractions were washed with brine $(80 \mathrm{~mL})$ and dried over $\mathrm{MgSO}_{4}$ followed by concentration in vacuo. The crude products were purified by flash chromatography $\left(\mathrm{CH}_{2} \mathrm{Cl}_{2} /\right.$ petroleum ether and/or EtOAc/petroleum ether as the eluent) to give the title compounds $\mathbf{1} \mathbf{f}-\mathbf{h}, \mathbf{j}, \mathbf{k}, \mathbf{n}$ as oils. Compounds $\mathbf{1 a}-\mathbf{e}, \mathbf{i}, \mathbf{l}, \mathbf{m}$ were commercially available.

Ethyl-3-oxoheptanoate (1f). ${ }^{47}$ Compound 1f was synthesized according to general procedure 1, using 1-bromopropane (2f, 2.00 $\mathrm{mL}, 22.0 \mathrm{mmol}, 1.10$ equiv) as starting compound. Compound was purified by silica column chromatography $(1-30 \%$ EtOAc in petroleum ether). Yield: $36 \%(1.25 \mathrm{~g})$ as a colorless oil. ${ }^{1} \mathrm{H}$ NMR $\left(400 \mathrm{MHz}, \mathrm{CDCl}_{3}\right) \delta 4.19(\mathrm{q}, J=7.2 \mathrm{~Hz}, 2 \mathrm{H}), 3.44(\mathrm{~s}, 2 \mathrm{H}), 2.54(\mathrm{t}, J$ $=7.4 \mathrm{~Hz}, 2 \mathrm{H}), 1.65-1.55(\mathrm{~m}, 2 \mathrm{H}), 1.38-1.25(\mathrm{~m}, 7 \mathrm{H}), 0.88(\mathrm{t}, J=$ $6.8 \mathrm{~Hz}, 3 \mathrm{H}) \mathrm{ppm}$.

Ethyl 5-Ethyl-3-oxoheptanoate (1g). Compound $1 \mathrm{~g}$ was synthesized according to general procedure 1, using 3-bromopentane $(2 \mathrm{~g}, 3.00 \mathrm{~mL}, 24.2 \mathrm{mmol}, 1.21$ equiv) as starting compound. Compound was purified by silica column chromatography $(1-30 \%$ EtOAc in petroleum ether). Yield: $18 \%(630 \mathrm{mg})$ as a yellow oil. ${ }^{1} \mathrm{H}$ NMR $\left(400 \mathrm{MHz}, \mathrm{CDCl}_{3}\right) \delta 4.17(\mathrm{q}, J=7.2 \mathrm{~Hz}, 2 \mathrm{H}), 3.40(\mathrm{~s}, 2 \mathrm{H})$, $2.43(\mathrm{~d}, J=6.8 \mathrm{~Hz}, 2 \mathrm{H}), 1.88-1.73(\mathrm{~m}, 1 \mathrm{H}), 1.33-1.21(\mathrm{~m}, 7 \mathrm{H})$, $0.82(\mathrm{t}, J=7.4 \mathrm{~Hz}, 6 \mathrm{H}) \mathrm{ppm}$.

Ethyl 3-Oxooctanoate $(1 \mathrm{~h}){ }^{47}$ Compound $1 \mathrm{~h}$ was synthesized according to general procedure 1 , using 1-bromobutane $(2 \mathrm{~h}, 2.59 \mathrm{~mL}$, $24.1 \mathrm{mmol}, 1.21$ equiv) as starting compound. Compound was purified by silica column chromatography $(1-30 \%$ EtOAc in petroleum ether). Yield: $38 \%(1.41 \mathrm{~g})$ as a yellow oil. ${ }^{1} \mathrm{H}$ NMR $\left(400 \mathrm{MHz}, \mathrm{CDCl}_{3}\right) \delta 4.19(\mathrm{q}, J=7.2 \mathrm{~Hz}, 2 \mathrm{H}), 3.43(\mathrm{~s}, 2 \mathrm{H}), 2.53(\mathrm{t}, J$ $=7.2 \mathrm{~Hz}, 2 \mathrm{H}), 1.65-1.55(\mathrm{~m}, 2 \mathrm{H}), 1.37-1.12(\mathrm{~m}, 7 \mathrm{H}), 0.89(\mathrm{t}, J=$ $7.2 \mathrm{~Hz}, 3 \mathrm{H}) \mathrm{ppm}$.

Ethyl 3-Oxononanoate $(1 \mathbf{j}){ }^{47}$ Compound $\mathbf{1 j}$ was synthesized according to general procedure 1 , using 1-iodopentane $(2 \mathbf{j}, 3.13 \mathrm{~mL}$, $24.0 \mathrm{mmol}, 1.20$ equiv) as starting compound. Compound was purified by silica column chromatography (1-30\% EtOAc in petroleum ether). Yield: $44 \%(1.76 \mathrm{~g})$ as a yellow oil. ${ }^{1} \mathrm{H}$ NMR $\left(400 \mathrm{MHz}, \mathrm{CDCl}_{3}\right) \delta 4.19(\mathrm{q}, J=7.2 \mathrm{~Hz}, 2 \mathrm{H}), 3.43(\mathrm{~s}, 2 \mathrm{H}), 2.53(\mathrm{t}, J$ $=7.4 \mathrm{~Hz}, 2 \mathrm{H}), 1.54-1.64(\mathrm{~m}, 2 \mathrm{H}), 1.33-1.24(\mathrm{~m}, 9 \mathrm{H}), 0.88(\mathrm{t}, J=$ $6.8 \mathrm{~Hz}, 3 \mathrm{H}) \mathrm{ppm}$.

Ethyl 3-Oxodecanoate $(1 \mathrm{k}){ }^{48}$ Compound $1 \mathrm{k}$ was synthesized according to general procedure 1 using 1-bromohexane $(2 \mathbf{k}, 3.36 \mathrm{~mL}$, $25.0 \mathrm{mmol}, 1.24$ equiv) as starting compound. Compound was purified by silica column chromatography $\left(30-100 \% \mathrm{CH}_{2} \mathrm{Cl}_{2}\right.$ in petroleum ether). Yield: $15 \%(625 \mathrm{mg})$ as a yellow oil. ${ }^{1} \mathrm{H}$ NMR $(400$ $\left.\mathrm{MHz}, \mathrm{CDCl}_{3}\right) \delta 4.19(\mathrm{q}, J=7.2 \mathrm{~Hz}, 2 \mathrm{H}), 3.43(\mathrm{~s}, 2 \mathrm{H}), 2.53(\mathrm{t}, J=7.4$ $\mathrm{Hz}, 2 \mathrm{H}), 1.64-1.53(\mathrm{~m}, 2 \mathrm{H}), 1.33-1.24(\mathrm{~m}, 11 \mathrm{H}), 0.88(\mathrm{t}, J=7.5$ $\mathrm{Hz}, 3 \mathrm{H}) \mathrm{ppm}$.

Ethyl 3-Oxo-5-phenylpentanoate (1n). ${ }^{49}$ Compound 1n was synthesized according to general procedure 1 , using benzyl bromide (2n, $2.90 \mathrm{~mL}, 24.4 \mathrm{mmol}, 1.22$ equiv) as starting compound. Compound was purified by silica column chromatography $(1-30 \%$ EtOAc in petroleum ether). Yield: $20 \%(1.06 \mathrm{~g})$ as a colorless oil. ${ }^{1} \mathrm{H}$ NMR (400 MHz, $\left.\mathrm{CDCl}_{3}\right) \delta 7.33-7.23(\mathrm{~m}, 2 \mathrm{H}), 7.23-7.12(\mathrm{~m}, 3 \mathrm{H})$, $4.17(\mathrm{q}, J=7.2 \mathrm{~Hz}, 2 \mathrm{H}), 3.42(\mathrm{~s}, 2 \mathrm{H}), 2.98-2.81(\mathrm{~m}, 4 \mathrm{H}), 1.26(\mathrm{t}, J=$ $7.2 \mathrm{~Hz}, 3 \mathrm{H}) \mathrm{ppm}$.

General Procedure 2. Benzylated $\beta$-Keto Esters 4aa-na, $\mathbf{4} \mathbf{b b}-\mathbf{b q}, \mathbf{4 e q - e v}{ }^{23} \mathrm{LiCl}$ (1.00 equiv) was slurried in anhydrous THF $(1 \mathrm{~mL} / \mathrm{mmol} \mathbf{1 a}-\mathbf{n})$ in a flame-dried round-bottom flask and under an atmosphere of nitrogen. The desired $\beta$-keto ester 1a-n
( 1.00 equiv) was added and followed by DIPEA ( 2.00 equiv) and the respective benzylic halide $3 \mathbf{a}-\mathbf{v}$ ( 1.20 equiv). The reaction mixture was refluxed for $20 \mathrm{~h}$, after which the reaction was completed as indicated by TLC (5-10\% EtOAc in petroleum ether). THF was removed in vacuo, the crude dissolved in EtOAc $(30 \mathrm{~mL})$, and this organic layer was washed with citric acid $(5 \%, 25 \mathrm{~mL})$ followed by saturated $\mathrm{NaHCO}_{3}(25 \mathrm{~mL})$ and brine $(25 \mathrm{~mL})$. The organic layer was subsequently dried over $\mathrm{MgSO}_{4}$, and concentrated in vacuo to afford the crude product. The crude product was purified by flash column chromatography (5-10\% EtOAc/petroleum ether) to yield the corresponding benzylated $\beta$-keto esters $4 \mathbf{a a}-\mathbf{n a}, \mathbf{4 b b}-\mathbf{b q}, \mathbf{4 e q}-$ ev.

Ethyl 2-(3-Chlorobenzyl)-3-oxobutanoate (4aa)..$^{23}$ Compound was synthesized according to general procedure 2 , using the following reagents: ethyl 3-oxobutanoate 1a $(0.37 \mathrm{~mL}, 2.92 \mathrm{mmol}$, 1.20 equiv), 3-chlorobenzyl bromide $3 \mathrm{a}(0.32 \mathrm{mmol}, 2.43 \mathrm{mmol}, 1.00$ equiv), DIPEA ( $0.85 \mathrm{~mL}, 4.86 \mathrm{mmol}, 2.00$ equiv), $\mathrm{LiCl}(103 \mathrm{mg}, 2.43$ mmol, 1.00 equiv), $5 \mathrm{~mL}$ of dry THF. Yield: $70 \%(433 \mathrm{mg})$ as a colorless oil. ${ }^{1} \mathrm{H}$ NMR: $\left(400 \mathrm{MHz}, \mathrm{CDCl}_{3}\right): \delta 7.21-7.14(\mathrm{~m}, 3 \mathrm{H})$, $7.09-7.04(\mathrm{~m}, 1 \mathrm{H}), 4.16(\mathrm{q}, J=7.2 \mathrm{~Hz}, 2 \mathrm{H}), 3.75(\mathrm{t}, J=8.0 \mathrm{~Hz}, 1 \mathrm{H})$, 3.17-3.07 (m, 2H), $2.21(\mathrm{~s}, 3 \mathrm{H}), 1.21(\mathrm{t}, J=7.2 \mathrm{~Hz}, 3 \mathrm{H}) \mathrm{ppm}$.

Ethyl 3-cyclopropyl-2-(3-chlorobenzyl)-3-oxopropanoate (4ba). ${ }^{23}$ Compound was synthesized according to general procedure 2 , using the following reagents: ethyl 3-cyclopropyl-3-oxopropanoate 1 b $(7.56 \mathrm{~mL}, 51.2 \mathrm{mmol}, 1.00$ equiv), 3-chlorobenzyl bromide 3a (7.06 mL, $53.8 \mathrm{mmol}, 1.05$ equiv), DIPEA ( $17.8 \mathrm{~mL}, 102 \mathrm{mmol}, 2.00$ equiv), $\mathrm{LiCl}(2.17 \mathrm{~g}, 51.22 \mathrm{mmol}, 1.00$ equiv), $5 \mathrm{~mL}$ of dry THF. Yield: $71 \%(10.2 \mathrm{~g})$ as a colorless oil. ${ }^{1} \mathrm{H}$ NMR $\left(400 \mathrm{MHz}, \mathrm{CDCl}_{3}\right) \delta$ $7.21-7.16(\mathrm{~m}, 3 \mathrm{H}), 7.10-7.05(\mathrm{~m}, 1 \mathrm{H}), 4.17(\mathrm{qd}, J=7.2,1.6 \mathrm{~Hz}$, $2 \mathrm{H}), 3.89(\mathrm{t}, J=7.6 \mathrm{~Hz}, 1 \mathrm{H}), 3.15(\mathrm{dd}, J=7.2 \mathrm{~Hz}, 2 \mathrm{H}), 2.08-2.02$ $(\mathrm{m}, 1 \mathrm{H}), 1.22(\mathrm{t}, J=7.2 \mathrm{~Hz}, 3 \mathrm{H}), 1.11-1.01(\mathrm{~m}, 2 \mathrm{H}), 0.98-0.88(\mathrm{~m}$, $2 \mathrm{H}) \mathrm{ppm}$.

Ethyl 2-Benzyl-3-cyclopropyl-3-oxopropanoate (4bb). ${ }^{24}$ Compound was synthesized according to general procedure 2, using the following reagents: ethyl 3-cyclopropyl-3-oxopropanoate $\mathbf{1 b}(0.52$ $\mathrm{mL}, 3.51 \mathrm{mmol}, 1.20$ equiv), benzyl bromide $3 \mathbf{b}(0.347 \mathrm{~mL}, 2.92$ mmol, 1.00 equiv), DIPEA ( $1.02 \mathrm{~mL}, 5.84 \mathrm{mmol}, 2.00$ equiv), $\mathrm{LiCl}$ (124 mg, $2.92 \mathrm{mmol}, 1.00$ equiv), $4 \mathrm{~mL}$ of dry THF. Yield: $26 \%$ (105 $\mathrm{mg}$ ) as a colorless oil. ${ }^{1} \mathrm{H}$ NMR $\left(400 \mathrm{MHz}, \mathrm{CDCl}_{3}\right) \delta 7.29-7.25(\mathrm{~m}$, $2 \mathrm{H}), 7.22-7.18(\mathrm{~m}, 3 \mathrm{H}), 4.20-4.12(\mathrm{~m}, 2 \mathrm{H}), 3.91(\mathrm{t}, J=7.6 \mathrm{~Hz}$, $1 \mathrm{H}), 3.20(\mathrm{~d}, J=7.6 \mathrm{~Hz}, 2 \mathrm{H}), 2.08-2.02(\mathrm{~m}, 1 \mathrm{H}), 1.20(\mathrm{t}, J=7.2 \mathrm{~Hz}$, $3 \mathrm{H}), 1.06-1.03(\mathrm{~m}, 2 \mathrm{H}), 0.94-0.84(\mathrm{~m}, 2 \mathrm{H}) \mathrm{ppm}$.

Ethyl 3-Cyclopropyl-2-(2-methylbenzyl)-3-oxopropanoate (4bc). Compound was synthesized according to general procedure 2 , using the following reagents: ethyl 3-cyclopropyl-3-oxopropanoate 1 b $(0.63 \mathrm{~mL}, 4.27 \mathrm{mmol}, 1.20$ equiv), 2-methylbenzyl chloride $3 \mathrm{c}$ ( $0.48 \mathrm{~mL}, 3.56 \mathrm{mmol}, 1.00$ equiv), DIPEA ( $1.24 \mathrm{~mL}, 7.12 \mathrm{mmol}, 2.00$ equiv), $\mathrm{LiCl}$ ( $151 \mathrm{mg}, 3.56 \mathrm{mmol}, 1.00$ equiv), $4 \mathrm{~mL}$ of dry THF. Yield: $80 \%(742 \mathrm{mg})$ as a colorless oil. ${ }^{1} \mathrm{H}$ NMR $\left(400 \mathrm{MHz}, \mathrm{CDCl}_{3}\right)$ $\delta 7.15-7.09(\mathrm{~m}, 4 \mathrm{H}), 4.16(\mathrm{qd}, J=7.2,1.2 \mathrm{~Hz}, 2 \mathrm{H}), 3.91(\mathrm{t}, J=7.2$ $\mathrm{Hz}, 1 \mathrm{H}), 3.20(\mathrm{~d}, J=7.6 \mathrm{~Hz}, 2 \mathrm{H}), 2.34(\mathrm{~s}, 3 \mathrm{H}), 2.05-2.00(\mathrm{~m}, 1 \mathrm{H})$, $1.20(\mathrm{t}, J=7.2 \mathrm{~Hz}, 3 \mathrm{H}), 1.07-1.02(\mathrm{~m}, 2 \mathrm{H}), 0.95-0.84(\mathrm{~m}, 2 \mathrm{H})$ ppm.

Ethyl 3-Cyclopropyl-2-(2-chlorobenzyl)-3-oxopropanoate (4bd). Compound was synthesized according to general procedure 2 , using the following reagents: ethyl 3-cyclopropyl-3-oxopropanoate 1 b (0.43 mL, $2.92 \mathrm{mmol}, 1.20$ equiv), 2-chlorobenzyl bromide 3d (0.32 mL, $2.43 \mathrm{mmol}, 1.00$ equiv), DIPEA $(0.85 \mathrm{~mL}, 4.86 \mathrm{mmol}, 2.00$ equiv), $\mathrm{LiCl}$ (103 mg, $2.43 \mathrm{mmol}, 1.00$ equiv), $5 \mathrm{~mL}$ of dry THF. Yield: $78 \%(532 \mathrm{mg})$ as a colorless oil. ${ }^{1} \mathrm{H}$ NMR $\left(400 \mathrm{MHz}, \mathrm{CDCl}_{3}\right)$ $\delta 7.36-7.33(\mathrm{~m}, 1 \mathrm{H}), 7.26-7.24(\mathrm{~m}, 1 \mathrm{H}), 7.18-7.14(\mathrm{~m}, 2 \mathrm{H}), 4.20-$ $4.08(\mathrm{~m}, 3 \mathrm{H}), 3.37-3.22(\mathrm{~m}, 2 \mathrm{H}), 2.10-2.03(\mathrm{~m}, 1 \mathrm{H}), 1.21(\mathrm{t}, J=$ $7.2 \mathrm{~Hz}, 3 \mathrm{H}), 1.09-1.01(\mathrm{~m}, 2 \mathrm{H}), 0.97-0.87(\mathrm{~m}, 2 \mathrm{H}) \mathrm{ppm}$.

Ethyl 3-Cyclopropyl-2-(2-methoxybenzyl)-3-oxopropanoate (4be). Compound was synthesized according to general procedure 2, using the following reagents: ethyl 3-cyclopropyl-3oxopropanoate $1 \mathbf{b}(0.33 \mathrm{~mL}, 2.26 \mathrm{mmol}, 1.20$ equiv), 2-methoxybenzyl bromide ${ }^{50} 3 \mathrm{e}(378 \mathrm{mg}, 1.88 \mathrm{mmol}, 1.00$ equiv), DIPEA (0.66 $\mathrm{mL}, 3.76 \mathrm{mmol}, 2.00$ equiv), $\mathrm{LiCl}(79.7 \mathrm{mg}, 1.88 \mathrm{mmol}, 1.00$ equiv), 5 $\mathrm{mL}$ of dry THF. Silica column chromatography in $8: 1: 1$ petroleum 
ether:EtOAc: $\mathrm{CH}_{2} \mathrm{Cl}_{2}$. Yield: $36 \%(185 \mathrm{mg})$ as a colorless oil. ${ }^{1} \mathrm{H}$ $\operatorname{NMR}\left(400 \mathrm{MHz}, \mathrm{CDCl}_{3}\right) \delta 7.20(\mathrm{td}, J=6.4,1.6 \mathrm{~Hz}, 1 \mathrm{H}), 7.13(\mathrm{dd}, J$ $=6.0,1.2 \mathrm{~Hz}, 1 \mathrm{H}), 6.86-6.26(\mathrm{~m}, 2 \mathrm{H}), 4.17-4.09(\mathrm{~m}, 2 \mathrm{H}), 4.04(\mathrm{dd}$, $J=6.8,1.6 \mathrm{~Hz}, 1 \mathrm{H}), 3.84(\mathrm{~s}, 3 \mathrm{H}), 3.42-3.11(\mathrm{~m}, 2 \mathrm{H}), 2.07-2.02(\mathrm{~m}$, $1 \mathrm{H}), 1.19(\mathrm{t}, J=6.0 \mathrm{~Hz}, 3 \mathrm{H}), 1.05-1.02(\mathrm{~m}, 2 \mathrm{H}), 0.92-0.85(\mathrm{~m}$, 2H) ppm.

Ethyl 3-Cyclopropyl-2-(3-methylbenzyl)-3-oxopropanoate (4bf). Compound was synthesized according to general procedure 2 , using the following reagents: ethyl 3-cyclopropyl-3-oxopropanoate 1 b $(0.47 \mathrm{~mL}, 3.24 \mathrm{mmol}, 1.20$ equiv $)$, 3-methylbenzyl bromide $3 \mathrm{f}$ (0.36 mL, $2.70 \mathrm{mmol}, 1.00$ equiv), DIPEA (0.94 mL, $5.40 \mathrm{mmol}, 2.00$ equiv), $\mathrm{LiCl}$ (114 mg, $2.70 \mathrm{mmol}, 1.00$ equiv), $5 \mathrm{~mL}$ of dry THF. Yield: $74 \%(521 \mathrm{mg})$ as a colorless oil. ${ }^{1} \mathrm{H}$ NMR $\left(400 \mathrm{MHz}, \mathrm{CDCl}_{3}\right)$ $\delta 7.17(\mathrm{t}, J=7.6 \mathrm{~Hz}, 1 \mathrm{H}), 7.02-6.96(\mathrm{~m}, 3 \mathrm{H}), 4.19-4.10(\mathrm{~m}, 2 \mathrm{H})$, $3.90(\mathrm{t}, J=7.6 \mathrm{~Hz}, 1 \mathrm{H}), 3.15(\mathrm{~d}, J=7.6 \mathrm{~Hz}, 2 \mathrm{H}), 2.30(\mathrm{~s}, 3 \mathrm{H}), 2.07-$ $2.01(\mathrm{~m}, 1 \mathrm{H}), 1.19(\mathrm{t}, J=7.2 \mathrm{~Hz}, 3 \mathrm{H}), 1.04-0.99(\mathrm{~m}, 2 \mathrm{H}), 0.93-$ $0.82(\mathrm{~m}, 2 \mathrm{H}) \mathrm{ppm}$.

Ethyl 3-Cyclopropyl-2-(3-fluorobenzyl)-3-oxopropanoate $(4 \mathrm{bg}) .{ }^{23}$ Compound was synthesized according to general procedure 2 , using the following reagents: ethyl 3-cyclopropyl-3-oxopropanoate 1 b $(0.550 \mathrm{~mL}, 3.73 \mathrm{mmol}, 1.31$ equiv), 3-fluorobenzyl bromide $3 \mathrm{~g}$ (0.350 mL, $2.85 \mathrm{mmol}, 1.00$ equiv), DIPEA $(0.940 \mathrm{~mL}, 5.39 \mathrm{mmol}$, 1.89 equiv), $\mathrm{LiCl}(0.140 \mathrm{~g}, 2.70 \mathrm{mmol}, 0.947$ equiv), $5 \mathrm{~mL}$ of dry THF. Yield: $100 \%(770 \mathrm{mg})$ as a yellow oil. ${ }^{1} \mathrm{H}$ NMR $(400 \mathrm{MHz}$, $\left.\mathrm{CDCl}_{3}\right) \delta 7.26-7.16(\mathrm{~m}, 1 \mathrm{H}), 6.97(\mathrm{~d}, J=8.0 \mathrm{~Hz}, 1 \mathrm{H}), 6.94-6.84$ $(\mathrm{m}, 2 \mathrm{H}), 4.19-4.11(\mathrm{~m}, 2 \mathrm{H}), 3.92(\mathrm{t}, J=7.6 \mathrm{~Hz}, 1 \mathrm{H}), 3.18(\mathrm{dd}, J=$ 7.6, $1.6 \mathrm{~Hz}, 2 \mathrm{H}), 2.10-2.04(\mathrm{~m}, 1 \mathrm{H}), 1.20(\mathrm{t}, J=7.2 \mathrm{~Hz}, 3 \mathrm{H}), 1.07-$ $0.98(\mathrm{~m}, 2 \mathrm{H}), 0.93-0.83(\mathrm{~m}, 2 \mathrm{H}) \mathrm{ppm}$.

Ethyl 2-(3-Bromobenzyl)-3-cyclopropyl-3-oxopropanoate (4bh). Compound was synthesized according to general procedure 2, using the following reagents: ethyl 3-cyclopropyl-3-oxopropanoate 1 b $(0.35 \mathrm{~mL}, 2.40 \mathrm{mmol}, 1.20$ equiv), 3-bromobenzyl bromide $3 \mathrm{~h}$ (500 mg, $2.00 \mathrm{mmol}, 1.00$ equiv), DIPEA $(0.70 \mathrm{~mL}, 4.00 \mathrm{mmol}, 2.00$ equiv), $\mathrm{LiCl}$ ( $85 \mathrm{mg}, 2.00 \mathrm{mmol}, 1.00$ equiv), $5 \mathrm{~mL}$ of dry THF. Yield: $47 \%(303 \mathrm{mg})$ as a colorless oil. ${ }^{1} \mathrm{H}$ NMR $\left(400 \mathrm{MHz}, \mathrm{CDCl}_{3}\right) \delta$ 7.36-7.32 (m, 2H), 7.17-7.10 (m, 2H), $4.17(\mathrm{q}, J=7.2 \mathrm{~Hz}, 2 \mathrm{H})$, $3.89(\mathrm{t}, J=7.2 \mathrm{~Hz}, 1 \mathrm{H}), 3.15(\mathrm{~d}, J=8.0 \mathrm{~Hz}, 2 \mathrm{H}), 2.08-2.01(\mathrm{~m}, 1 \mathrm{H})$, $1.22(\mathrm{t}, J=7.2 \mathrm{~Hz}, 3 \mathrm{H}), 1.11-1.01(\mathrm{~m}, 2 \mathrm{H}), 0.98-0.86(\mathrm{~m}, 2 \mathrm{H})$ ppm.

Ethyl 3-Cyclopropyl-2-(3-iodobenzyl)-3-oxopropanoate (4bi). Compound was synthesized according to general procedure 2 , using the following reagents: ethyl 3-cyclopropyl-3-oxopropanoate 1 b $(0.550 \mathrm{~mL}, 3.73 \mathrm{mmol}, 1.38$ equiv), 3-iodobenzyl bromide $3 \mathrm{i}$ (0.802 g, $2.70 \mathrm{mmol}, 1.00$ equiv), DIPEA (0.940 mL, $5.39 \mathrm{mmol}, 2.00$ equiv), $\mathrm{LiCl}(0.150 \mathrm{~g}, 2.70 \mathrm{mmol}, 1.00$ equiv), $5 \mathrm{~mL}$ of dry THF. Yield: quantitative $(1.28 \mathrm{~g})$ as a yellow oil. ${ }^{1} \mathrm{H}$ NMR $(400 \mathrm{MHz}$, $\left.\mathrm{CDCl}_{3}\right) \delta 7.55-7.51(\mathrm{~m}, 2 \mathrm{H}), 7.15(\mathrm{~d}, J=7.6 \mathrm{~Hz}, 1 \mathrm{H}), 6.99(\mathrm{t}, J=$ $7.6 \mathrm{~Hz}, 1 \mathrm{H}), 4.16(\mathrm{qd}, J=7.2,1.6 \mathrm{~Hz}, 2 \mathrm{H}), 3.87(\mathrm{t}, J=7.2 \mathrm{~Hz}, 1 \mathrm{H})$, $3.11(\mathrm{dd}, J=8.0,2.0 \mathrm{~Hz}, 2 \mathrm{H}), 2.06-2.00(\mathrm{~m}, 1 \mathrm{H}), 1.20(\mathrm{t}, J=6.8 \mathrm{~Hz}$, $3 \mathrm{H}), 1.11-1.00(\mathrm{~m}, 2 \mathrm{H}), 0.98-0.81(\mathrm{~m}, 2 \mathrm{H}) \mathrm{ppm}$.

Ethyl 3-Cyclopropyl-2-(3-methoxybenzyl)-3-oxopropanoate (4bj). ${ }^{51}$ Compound was synthesized according to general procedure 2, using the following reagents: ethyl 3-cyclopropyl-3oxopropanoate $\mathbf{1 b}(0.44 \mathrm{~mL}, 3.00 \mathrm{mmol}, 1.20$ equiv), 3-methoxybenzyl bromide $3 \mathbf{j}(0.35 \mathrm{~mL}, 2.50 \mathrm{mmol}, 1.00$ equiv), DIPEA $(0.87$ $\mathrm{mL}, 5.00 \mathrm{mmol}, 2.00$ equiv), $\mathrm{LiCl}$ ( $106 \mathrm{mg}, 2.50 \mathrm{mmol}, 1.00$ equiv), 5 $\mathrm{mL}$ of dry THF. Silica column chromatography in $8: 1: 1$ petroleum ether:EtOAc: $\mathrm{CH}_{2} \mathrm{Cl}_{2}$. Yield: $42 \%(294 \mathrm{mg})$ as a colorless oil. ${ }^{1} \mathrm{H}$ NMR $\left(400 \mathrm{MHz}, \mathrm{CDCl}_{3}\right) \delta 7.19(\mathrm{td}, J=7.2 \mathrm{~Hz}, 1.2 \mathrm{~Hz}, 1 \mathrm{H}), 6.79-$ $6.74(\mathrm{~m}, 3 \mathrm{H}), 4.21-4.13(\mathrm{~m}, 2 \mathrm{H}), 3.91(\mathrm{t}, J=7.6 \mathrm{~Hz}, 1 \mathrm{H}), 3.78(\mathrm{~s}$, $3 \mathrm{H}), 3.17(\mathrm{~d}, J=7.6 \mathrm{~Hz}, 2 \mathrm{H}), 2.08-2.02(\mathrm{~m}, 1 \mathrm{H}), 1.22(\mathrm{t}, J=7.2 \mathrm{~Hz}$, $3 \mathrm{H}), 1.06-1.01(\mathrm{~m}, 2 \mathrm{H}), 0.96-0.85(\mathrm{~m}, 2 \mathrm{H}) \mathrm{ppm}$.

Ethyl 3-Cyclopropyl-3-oxo-2-(3-(trifluoromethyl)benzyl)propanoate $(\mathbf{4 b k}) .{ }^{24}$ Compound was synthesized according to general procedure 2, using the following reagents: ethyl 3-cyclopropyl3-oxopropanoate $1 \mathbf{b}(0.37 \mathrm{~mL}, 2.51 \mathrm{mmol}, 1.20$ equiv), 3(trifluoromethyl)benzyl bromide 3k $(0.32 \mathrm{~mL}, 2.09 \mathrm{mmol}, 1.00$ equiv), DIPEA (0.73 mL, $4.18 \mathrm{mmol}, 2.00$ equiv), $\mathrm{LiCl}(89 \mathrm{mg}, 2.09$ mmol, 1.00 equiv), $5 \mathrm{~mL}$ of dry THF. Yield: $31 \%(214 \mathrm{mg})$ as a colorless oil. ${ }^{1} \mathrm{H}$ NMR (400 MHz, $\left.\mathrm{CDCl}_{3}\right) \delta 7.50-7.44(\mathrm{~m}, 2 \mathrm{H})$, $7.42-7.38(\mathrm{~m}, 2 \mathrm{H}), 4.17(\mathrm{q}, J=6.8 \mathrm{~Hz}, 2 \mathrm{H}), 3.92(\mathrm{t}, J=8.0 \mathrm{~Hz}, 1 \mathrm{H})$, $3.25(\mathrm{~d}, J=7.2 \mathrm{~Hz}, 2 \mathrm{H}), 2.10-2.02(\mathrm{~m}, 1 \mathrm{H}), 1.21(\mathrm{t}, J=7.2 \mathrm{~Hz}, 3 \mathrm{H})$, $1.12-1.01(\mathrm{~m}, 2 \mathrm{H}), 0.99-0.86(\mathrm{~m}, 2 \mathrm{H}) \mathrm{ppm}$

Ethyl 3-Cyclopropyl-2-(4-methylbenzyl)-3-oxopropanoate (4bl). Compound was synthesized according to general procedure 2, using the following reagents: ethyl 3-cyclopropyl-3-oxopropanoate 1 b $(0.48 \mathrm{~mL}, 3.24 \mathrm{mmol}, 1.20$ equiv), 4-methylbenzyl bromide 31 (500 mg, $2.70 \mathrm{mmol}, 1.00$ equiv), DIPEA (0.94 mL, $5.40 \mathrm{mmol}, 2.00$ equiv), $\mathrm{LiCl}$ (114 mg, $2.70 \mathrm{mmol}, 1.00$ equiv), $5 \mathrm{~mL}$ of dry THF. Yield: $74 \%(521 \mathrm{mg})$ as a colorless oil. ${ }^{1} \mathrm{H}$ NMR $\left(400 \mathrm{MHz}, \mathrm{CDCl}_{3}\right)$ $\delta 7.08(\mathrm{~s}, 4 \mathrm{H}), 4.22-4.09(\mathrm{~m}, 2 \mathrm{H}), 3.88(\mathrm{t}, J=7.6 \mathrm{~Hz}, 1 \mathrm{H}), 3.15(\mathrm{~d}, J$ $=7.6 \mathrm{~Hz}, 2 \mathrm{H}), 2.30(\mathrm{~s}, 3 \mathrm{H}), 2.07-2.02(\mathrm{~m}, 1 \mathrm{H}), 1.21(\mathrm{t}, J=7.2 \mathrm{~Hz}$, $3 \mathrm{H}), 1.07-1.02(\mathrm{~m}, 2 \mathrm{H}), 0.96-0.83(\mathrm{~m}, 2 \mathrm{H}) \mathrm{ppm}$.

Ethyl 3-Cyclopropyl-2-(4-fluorobenzyl)-3-oxopropanoate $(4 \mathrm{bm})$. Compound was synthesized according to general procedure 2 , using the following reagents: ethyl 3-cyclopropyl-3-oxopropanoate 1b $(0.890 \mathrm{~mL}, 6.04 \mathrm{mmol}, 1.14$ equiv), 1-(bromomethyl)-4fluorobenzene $3 \mathrm{~m}$ ( $1.57 \mathrm{~g}, 5.29 \mathrm{mmol}, 1.00$ equiv), DIPEA (1.05 $\mathrm{mL}, 6.00 \mathrm{mmol}, 1.13$ equiv), $\mathrm{LiCl}(0.130 \mathrm{~g}, 3.00 \mathrm{mmol}, 0.58$ equiv $), 5$ $\mathrm{mL}$ of dry THF. Yield: $56 \%(780 \mathrm{mg})$ as a yellow oil. ${ }^{1} \mathrm{H}$ NMR $(400$ $\left.\mathrm{MHz}, \mathrm{CDCl}_{3}\right) \delta 7.18-7.12(\mathrm{~m}, 2 \mathrm{H}), 6.96(\mathrm{tt}, J=8.8,2.0 \mathrm{~Hz}, 2 \mathrm{H})$, $4.22-4.10(\mathrm{~m}, 2 \mathrm{H}), 3.87(\mathrm{t}, J=8.0 \mathrm{~Hz}, 1 \mathrm{H}), 3.16(\mathrm{~d}, J=7.6 \mathrm{~Hz}, 2 \mathrm{H})$, $2.08-2.00(\mathrm{~m}, 1 \mathrm{H}), 1.21(\mathrm{t}, J=7.2 \mathrm{~Hz}, 3 \mathrm{H}), 1.09-0.99(\mathrm{~m}, 2 \mathrm{H})$, $0.97-0.84(\mathrm{~m}, 2 \mathrm{H}) \mathrm{ppm}$.

Ethyl 2-(4-Chlorobenzyl)-3-cyclopropyl-3-oxopropanoate (4bn). Compound was synthesized according to general procedure 2, using the following reagents: ethyl 3-cyclopropyl-3-oxopropanoate 1 b $(0.43 \mathrm{~mL}, 2.92 \mathrm{mmol}, 1.20$ equiv), 4-chlorobenzyl bromide $3 \mathbf{n}$ (500 mg, $2.43 \mathrm{mmol}, 1.00$ equiv), DIPEA ( $0.85 \mathrm{~mL}, 4.86 \mathrm{mmol}, 2.00$ equiv), $\mathrm{LiCl}$ ( $103 \mathrm{mg}, 2.43 \mathrm{mmol}, 1.00$ equiv), $5 \mathrm{~mL}$ of dry THF. Yield: $66 \%(451 \mathrm{mg})$ as a colorless oil. ${ }^{1} \mathrm{H}$ NMR $\left(400 \mathrm{MHz}, \mathrm{CDCl}_{3}\right)$ $\delta 7.24(\mathrm{dt} J=8.8,2.0 \mathrm{~Hz}, 2 \mathrm{H}), 7.13(\mathrm{dt}, J=8.4,2.0 \mathrm{~Hz}, 2 \mathrm{H}), 4.21-$ $4.11(\mathrm{~m}, 2 \mathrm{H}), 3.87(\mathrm{dd}, J=8.0,0.8 \mathrm{~Hz}, 1 \mathrm{H}), 3.15(\mathrm{dd}, J=6.8,1.2 \mathrm{~Hz}$, $2 \mathrm{H}), 2.08-2.01(\mathrm{~m}, 1 \mathrm{H}), 1.21(\mathrm{t}, J=7.2 \mathrm{~Hz}, 3 \mathrm{H}), 1.09-1.01(\mathrm{~m}$, $2 \mathrm{H}), 0.97-0.86(\mathrm{~m}, 2 \mathrm{H}) \mathrm{ppm}$.

Ethyl 2-(4-Bromobenzyl)-3-cyclopropyl-3-oxopropanoate (4bo). Compound was synthesized according to general procedure 2 , using the following reagents: ethyl 3-cyclopropyl-3-oxopropanoate lb $(0.880 \mathrm{~mL}, 5.97 \mathrm{mmol}, 1.49$ equiv), 1-(bromomethyl)-4bromobenzene $3 \mathrm{o}(1.00 \mathrm{~g}, 4.00 \mathrm{mmol}, 1.00$ equiv), DIPEA (1.39 $\mathrm{mL}, 8.00 \mathrm{mmol}, 2.00$ equiv), $\mathrm{LiCl}(0.170 \mathrm{~g}, 4.00 \mathrm{mmol}, 1.00$ equiv), 5 $\mathrm{mL}$ of dry THF. Yield: $67 \%(0.880 \mathrm{~g})$ as a yellow oil. ${ }^{1} \mathrm{H}$ NMR $(400$ $\left.\mathrm{MHz}, \mathrm{CDCl}_{3}\right) \delta 7.39(\mathrm{~d}, J=8.4 \mathrm{~Hz}, 2 \mathrm{H}), 7.07(\mathrm{~d}, J=8.4 \mathrm{~Hz}, 2 \mathrm{H})$, $4.22-4.10(\mathrm{~m}, 2 \mathrm{H}), 3.87(\mathrm{t}, J=8.0 \mathrm{~Hz}, 1 \mathrm{H}), 3.14(\mathrm{~d}, J=8.2 \mathrm{~Hz}, 2 \mathrm{H})$, $2.08-1.96(\mathrm{~m}, 1 \mathrm{H}), 1.22(\mathrm{t}, J=7.2 \mathrm{~Hz}, 3 \mathrm{H}), 1.10-0.99(\mathrm{~m}, 2 \mathrm{H})$, $0.99-0.85(\mathrm{~m}, 2 \mathrm{H}) \mathrm{ppm}$.

Ethyl 3-Cyclopropyl-2-(4-methoxybenzyl)-3-oxopropanoate (4bp). Compound was synthesized according to general procedure 2, using the following reagents: ethyl 3-cyclopropyl-3oxopropanoate $1 \mathbf{b}(0.57 \mathrm{~mL}, 3.83 \mathrm{mmol}, 1.20$ equiv), 4-methoxybenzyl bromide $3 \mathrm{p}$ (0.46 mL, $3.19 \mathrm{mmol}, 1.00$ equiv), DIPEA (1.11 $\mathrm{mL}, 6.38 \mathrm{mmol}, 2.00$ equiv), $\mathrm{LiCl}$ ( $135 \mathrm{mg}, 3.19 \mathrm{mmol}, 1.00$ equiv), 5 $\mathrm{mL}$ of dry THF. Silica column chromatography in 7:1:2 petroleum ether:EtOAc: $\mathrm{CH}_{2} \mathrm{Cl}_{2}$. Yield: $52 \%(454 \mathrm{mg})$ as a colorless oil. ${ }^{1} \mathrm{H}$ $\operatorname{NMR}\left(400 \mathrm{MHz}, \mathrm{CDCl}_{3}\right) \delta 7.10(\mathrm{dt}, J=8.8,2.0 \mathrm{~Hz}, 2 \mathrm{H}), 6.81(\mathrm{dt}, J$ $=8.8,2.4 \mathrm{~Hz}, 2 \mathrm{H}), 4.20-4.10(\mathrm{~m}, 2 \mathrm{H}), 3.86(\mathrm{t}, J=7.6 \mathrm{~Hz}, 1 \mathrm{H}), 3.78$ $(\mathrm{s}, 3 \mathrm{H}), 3.13(\mathrm{~d}, J=7.6 \mathrm{~Hz}, 2 \mathrm{H}), 2.07-2.01(\mathrm{~m}, 1 \mathrm{H}), 1.21(\mathrm{t}, J=7.2$ $\mathrm{Hz}, 3 \mathrm{H}), 1.08-1.01(\mathrm{~m}, 2 \mathrm{H}), 0.95-0.83(\mathrm{~m}, 2 \mathrm{H}) \mathrm{ppm}$.

Ethyl 3-Cyclopropyl-2-(3,4-dichlorobenzyl)-3-oxopropanoate (4bq). ${ }^{23}$ Compound was synthesized according to general procedure 2, using the following reagents: ethyl 3-cyclopropyl-3oxopropanoate $1 \mathbf{b}(0.60 \mathrm{~mL}, 4.06 \mathrm{mmol}, 1.00$ equiv $), 3,4-$ dichlorobenzyl bromide 3q $(0.62 \mathrm{~mL}, 4.27 \mathrm{mmol}, 1.05$ equiv), DIPEA (1.42 mL, $8.13 \mathrm{mmol}, 2.00$ equiv), $\mathrm{LiCl}(172 \mathrm{mg}, 4.06 \mathrm{mmol}$, 1.00 equiv), $5 \mathrm{~mL}$ of dry THF. Yield: $39 \%(493 \mathrm{mg})$ as a colorless oil. ${ }^{1} \mathrm{H}$ NMR $\left(400 \mathrm{MHz}, \mathrm{CDCl}_{3}\right) \delta 7.33(\mathrm{~d}, J=8.4 \mathrm{~Hz}, 1 \mathrm{H}), 7.30(\mathrm{~d}, J=$ $1.6 \mathrm{~Hz}, 1 \mathrm{H}), 7.03(\mathrm{dd}, J=8.4,2.0 \mathrm{~Hz}, 1 \mathrm{H}), 4.22-4.12(\mathrm{~m}, 2 \mathrm{H}), 3.87$ $(\mathrm{t}, J=7.6 \mathrm{~Hz}, 1 \mathrm{H}), 3.18-3.09(\mathrm{~m}, 2 \mathrm{H}), 2.09-2.02(\mathrm{~m}, 1 \mathrm{H}), 1.23(\mathrm{t}, J$ $=7.2 \mathrm{~Hz}, 3 \mathrm{H}), 1.09-1.01(\mathrm{~m}, 2 \mathrm{H}), 0.95-0.85(\mathrm{~m}, 2 \mathrm{H}) \mathrm{ppm}$. 
Ethyl 2-(3-Chlorobenzyl)-3-oxopentanoate (4ca). ${ }^{52}$ Compound was synthesized according to general procedure 2 , using the following reagents: ethyl 3-oxopentanoate $1 \mathrm{c}(0.42 \mathrm{~mL}, 2.92 \mathrm{mmol}$, 1.20 equiv), 3-chlorobenzyl bromide $3 \mathrm{a}(0.32 \mathrm{~mL}, 2.43 \mathrm{mmol}, 1.00$ equiv), $\mathrm{NaH}$ ( $117 \mathrm{mg}, 4.86 \mathrm{mmol}, 2.00$ equiv), $5 \mathrm{~mL}$ of dry THF. Yield: $52 \%(340 \mathrm{mg})$ as a colorless oil. ${ }^{1} \mathrm{H}$ NMR $\left(500 \mathrm{MHz}, \mathrm{CDCl}_{3}\right)$ : $\delta 7.20-7.14(\mathrm{~m}, 3 \mathrm{H}), 7.09-7.03(\mathrm{~m}, 1 \mathrm{H}), 4.15(\mathrm{qd}, J=7.5,0.8 \mathrm{~Hz}$, $2 \mathrm{H}), 3.76(\mathrm{t}, J=7.5 \mathrm{~Hz}, 1 \mathrm{H}), 3.17-3.08(\mathrm{~m}, 2 \mathrm{H}), 2.60(\mathrm{dqd}, J=18.0$, 7.0, $1.0 \mathrm{~Hz}, 1 \mathrm{H}), 2.37(\mathrm{dqd}, J=18.5,7.0,0.5 \mathrm{~Hz}, 1 \mathrm{H}), 1.20(\mathrm{td}, J=$ $7.0,1.0 \mathrm{~Hz}, 3 \mathrm{H}), 1.01(\mathrm{td}, J=7.5,1.0 \mathrm{~Hz}, 3 \mathrm{H}) \mathrm{ppm}$.

Ethyl 2-(3-Chlorobenzyl)-3-oxohexanoate (4da). ${ }^{23} \mathrm{Com}$ pound was synthesized according to general procedure 2, using the following reagents: ethyl 3-oxohexanoate $1 \mathrm{~d}(0.46 \mathrm{~mL}, 2.92 \mathrm{mmol}$, 1.20 equiv), $2.43 \mathrm{mmol}$ of 3 -chlorobenzyl bromide 3a, DIPEA ( 0.85 mmol, $4.86 \mathrm{mmol}, 2.00$ equiv), $\mathrm{LiCl}(103 \mathrm{mg}, 2.43 \mathrm{mmol}, 1.00$ equiv), $5 \mathrm{~mL}$ of dry THF. Yield: $76 \%(522 \mathrm{mg})$ as a colorless oil. ${ }^{1} \mathrm{H}$ NMR $\left(400 \mathrm{MHz}, \mathrm{CDCl}_{3}\right): \delta 7.22-7.14(\mathrm{~m}, 3 \mathrm{H}), 7.08-7.04(\mathrm{~m}, 1 \mathrm{H}), 4.15$ (q, $J=7.2 \mathrm{~Hz}, 2 \mathrm{H}), 3.75(\mathrm{t}, J=7.6 \mathrm{~Hz}, 1 \mathrm{H}), 3.18-3.07(\mathrm{~m}, 2 \mathrm{H}), 2.54$ $(\mathrm{dt}, \mathrm{J}=17.6,7.2 \mathrm{~Hz}, 1 \mathrm{H}), 2.35(\mathrm{dt}, J=17.2,7.2 \mathrm{~Hz}, 1 \mathrm{H}), 1.57$ (sextet, $J=7.2 \mathrm{~Hz}, 2 \mathrm{H}), 1.21(\mathrm{t}, J=7.2 \mathrm{~Hz}, 3 \mathrm{H}), 0.85(\mathrm{t}, J=7.6 \mathrm{~Hz}, 3 \mathrm{H})$ ppm.

Ethyl 2-(3-Chlorobenzyl)-4-methyl-3-oxopentanoate (4ea). ${ }^{23}$ Compound was synthesized according to general procedure 2, using the following reagents: ethyl 4-methyl-3-oxopentanoate 1e (0.51 mL, $3.16 \mathrm{mmol}, 1.20$ equiv), 3-chlorobenzyl bromide 3a (0.35 $\mathrm{mL}, 2.63 \mathrm{mmol}, 1.00$ equiv), DIPEA (0.95 mL, $5.26 \mathrm{mmol}, 2.00$ equiv), $\mathrm{LiCl}(111 \mathrm{mg}, 2.63 \mathrm{mmol}, 1.00$ equiv), $5 \mathrm{~mL}$ of dry THF. Yield: $86 \%(640 \mathrm{mg})$ as a colorless oil. ${ }^{1} \mathrm{H}$ NMR $\left(400 \mathrm{MHz}, \mathrm{CDCl}_{3}\right)$ : $\delta 7.20-7.14(\mathrm{~m}, 3 \mathrm{H}), 7.07-7.04(\mathrm{~m}, 1 \mathrm{H}), 4.14(\mathrm{qd}, J=7.2,0.8 \mathrm{~Hz}$, $2 \mathrm{H}), 3.91(\mathrm{t}, J=7.6 \mathrm{~Hz}, 1 \mathrm{H}), 3.17-3.07(\mathrm{~m}, 2 \mathrm{H}), 2.66$ (septet, $J=$ $6.8 \mathrm{~Hz}, 1 \mathrm{H}), 1.21(\mathrm{t}, J=7.2 \mathrm{~Hz}, 3 \mathrm{H}), 1.07(\mathrm{~d}, J=6.8 \mathrm{~Hz}, 3 \mathrm{H}), 0.91$ (d, $J=7.2 \mathrm{~Hz}, 3 \mathrm{H})$ ppm.

Ethyl 2-(3,4-Dichlorobenzyl)-4-methyl-3-oxopentanoate (4eq). ${ }^{24}$ Compound was synthesized according to general procedure 2, using the following reagents: ethyl 4-methyl-3-oxopentanoate 1e (5.00 mL, $31.0 \mathrm{mmol}, 1.00$ equiv), 3,4-dichlorobenzyl bromide $3 \mathrm{q}$ (5.41 mL, $37.2 \mathrm{mmol}, 1.20$ equiv), DIPEA ( $10.8 \mathrm{~mL}, 62.0 \mathrm{mmol}, 2.00$ equiv), $\mathrm{LiCl}(1.31 \mathrm{~g}, 30.9 \mathrm{mmol}, 1.00$ equiv), $50 \mathrm{~mL}$ of dry THF. Yield: $33 \%(3.20 \mathrm{~g})$ as a yellow oil. ${ }^{1} \mathrm{H}$ NMR $\left(400 \mathrm{MHz} \mathrm{CDCl}_{3}\right) \delta$ $7.33(\mathrm{~d}, J=8.4 \mathrm{~Hz}, 1 \mathrm{H}), 7.29-7.25(\mathrm{~m}, 1 \mathrm{H}), 7.01(\mathrm{dd}, J=8.0,2.0$ $\mathrm{Hz}, 1 \mathrm{H}), 4.15(\mathrm{qd}, J=7.2,1.6 \mathrm{~Hz}, 2 \mathrm{H}), 3.89(\mathrm{t}, J=7.6 \mathrm{~Hz}, 1 \mathrm{H})$, $3.16-3.04(\mathrm{~m}, 2 \mathrm{H}), 2.69$ (heptet, $J=6.8 \mathrm{~Hz}, 1 \mathrm{H}), 1.22(\mathrm{t}, J=7.2 \mathrm{~Hz}$, $3 \mathrm{H}), 1.07(\mathrm{~d}, J=6.4 \mathrm{~Hz}, 3 \mathrm{H}), 0.93(\mathrm{~d}, J=7.2 \mathrm{~Hz}, 3 \mathrm{H}) \mathrm{ppm}$.

Ethyl 2-(2,3-Dichlorobenzyl)-4-methyl-3-oxopentanoate (4er). Compound was synthesized according to general procedure 2 , using the following reagents: ethyl 4-methyl-3-oxopentanoate $1 \mathrm{e}$ ( $0.670 \mathrm{~mL}, 4.61 \mathrm{mmol}, 1.00$ equiv), 2,3-dichlorobenzyl bromide $3 \mathbf{r}$ ( $1.00 \mathrm{~g}$, $4.17 \mathrm{mmol}, 0.90$ equiv), DIPEA ( $1.45 \mathrm{~mL}, 8.34 \mathrm{mmol}, 1.81$ equiv), $\mathrm{LiCl}(180 \mathrm{mg}, 0.90 \mathrm{mmol}, 1.00$ equiv), $5 \mathrm{~mL}$ of dry THF. Yield: $8 \%(110 \mathrm{mg})$ as a yellow oil. ${ }^{1} \mathrm{H}$ NMR $\left(400 \mathrm{MHz}, \mathrm{CDCl}_{3}\right) \delta$ $7.34(\mathrm{dd}, J=7.6,1.6 \mathrm{~Hz}, 1 \mathrm{H}), 7.15(\mathrm{dd}, J=7.6,1.6 \mathrm{~Hz}, 1 \mathrm{H}), 7.09(\mathrm{t}, J$ $=7.6 \mathrm{~Hz}, 1 \mathrm{H}), 4.20-4.03(\mathrm{~m}, 3 \mathrm{H}), 3.34-3.22(\mathrm{~m}, 2 \mathrm{H}), 2.71$ (heptet, $J=6.8 \mathrm{~Hz}, 1 \mathrm{H}), 1.19(\mathrm{t}, J=7.2 \mathrm{~Hz}, 3 \mathrm{H}), 1.07(\mathrm{~d}, J=6.8 \mathrm{~Hz}, 3 \mathrm{H})$, $0.90(\mathrm{~d}, J=6.8 \mathrm{~Hz}, 3 \mathrm{H}) \mathrm{ppm}$.

Ethyl 2-(2,5-Dichlorobenzyl)-4-methyl-3-oxopentanoate (4es). Compound was synthesized according to general procedure 2, using the following reagents: ethyl 4-methyl-3-oxopentanoate 1e (0.204 mL, $1.39 \mathrm{mmol}, 1.00$ equiv), 2,5-dichlorobenzyl bromide $3 \mathrm{~s}$ (500 mg, $2.08 \mathrm{mmol}, 1.5$ equiv), DIPEA $(0.242 \mathrm{~mL}, 1.39 \mathrm{mmol}, 1.00$ equiv), $\mathrm{LiCl}$ ( $60 \mathrm{mg}, 1.39 \mathrm{mmol}, 1.00$ equiv), $5 \mathrm{~mL}$ of dry THF. Yield: $71 \%(315 \mathrm{mg})$ as a colorless oil. ${ }^{1} \mathrm{H}$ NMR $\left(400 \mathrm{MHz}, \mathrm{CDCl}_{3}\right) \delta 7.27$ $(\mathrm{d}, J=8.8 \mathrm{~Hz}, 1 \mathrm{H}), 7.22(\mathrm{~d}, J=2.4 \mathrm{~Hz}, 1 \mathrm{H}), 7.15(\mathrm{dd}, J=8.4,2.4 \mathrm{~Hz}$, $1 \mathrm{H}), 4.18-4.12(\mathrm{~m}, 2 \mathrm{H}), 4.10(\mathrm{t}, J=7.2 \mathrm{~Hz}, 1 \mathrm{H}), 3.26-3.16(\mathrm{~m}, 2 \mathrm{H})$, 2.73 (heptet, $J=6.8 \mathrm{~Hz}, 1 \mathrm{H}), 1.22(\mathrm{t}, J=7.2 \mathrm{~Hz}, 3 \mathrm{H}), 1.08(\mathrm{~d}, J=6.8$ $\mathrm{Hz}, 3 \mathrm{H}), 0.93(\mathrm{~d}, J=7.2 \mathrm{~Hz}, 3 \mathrm{H}) \mathrm{ppm}$.

Ethyl 2-(3,5-Dichlorobenzyl)-4-methyl-3-oxopentanoate (4et). ${ }^{24}$ Compound was synthesized according to general procedure 2, using the following reagents: ethyl 4-methyl-3-oxopentanoate 1e ( $0.480 \mathrm{~mL}, 3.30 \mathrm{mmol}, 1.00$ equiv), 3,5-dichlorobenzyl bromide 3t (0.440 mL, $3.12 \mathrm{mmol}, 1.00$ equiv), DIPEA (1.05 mL, $6.00 \mathrm{mmol}$,
1.82 equiv), $\mathrm{LiCl}(0.310 \mathrm{~g}, 3.00 \mathrm{mmol}, 0.91$ equiv), $5 \mathrm{~mL}$ of dry THF. Yield: $16 \%(150 \mathrm{mg})$ as a yellow oil. ${ }^{1} \mathrm{H}$ NMR $\left(400 \mathrm{MHz}^{\mathrm{CDCl}}{ }_{3}\right) \delta$ $7.13(\mathrm{t}, J=2.0 \mathrm{~Hz}, 1 \mathrm{H}), 6.99(\mathrm{~d}, J=2.0 \mathrm{~Hz}, 2 \mathrm{H}), 4.08(\mathrm{q}, J=7.2 \mathrm{~Hz}$, $2 \mathrm{H}), 3.81(\mathrm{t}, J=7.6 \mathrm{~Hz}, 1 \mathrm{H}), 3.07-2.97(\mathrm{~m}, 2 \mathrm{H}), 2.63$ (heptet, $J=$ $6.8 \mathrm{~Hz}, 1 \mathrm{H}), 1.15(\mathrm{t}, J=7.2 \mathrm{~Hz}, 3 \mathrm{H}), 1.00(\mathrm{~d}, J=6.8 \mathrm{~Hz}, 3 \mathrm{H}), 0.87$ $(\mathrm{d}, J=6.8 \mathrm{~Hz}, 3 \mathrm{H}) \mathrm{ppm}$.

Ethyl 2-(3,5-Dibromobenzyl)-4-methyl-3-oxopentanoate (4eu). Compound was synthesized according to general procedure 2 , using the following reagents: ethyl 4-methyl-3-oxopentanoate 1e ( $0.480 \mathrm{~mL}, 3.30 \mathrm{mmol}, 1.00$ equiv), 3,5-dibromobenzyl bromide $3 \mathbf{u}$ ( $1.04 \mathrm{~g}, 3.16 \mathrm{mmol}, 0.958$ equiv), DIPEA ( $1.05 \mathrm{~mL}, 6.00 \mathrm{mmol}, 1.82$ equiv), $\mathrm{LiCl}(0.130 \mathrm{~g}, 3.00 \mathrm{mmol}, 0.909$ equiv), $5 \mathrm{~mL}$ of dry. THF. Yield: $29 \%(0.350 \mathrm{~g})$ as a yellow oil. ${ }^{1} \mathrm{H}$ NMR $\left(400 \mathrm{MHz} \mathrm{CDCl}_{3}\right) \delta$ $7.27(\mathrm{~s}, 3 \mathrm{H}), 4.15(\mathrm{q}, J=7.2 \mathrm{~Hz}, 2 \mathrm{H}), 3.87(\mathrm{t}, J=7.2 \mathrm{~Hz}, 1 \mathrm{H}), 3.13-$ $3.05(\mathrm{~m}, 2 \mathrm{H}), 2.70$ (heptet, $J=6.8 \mathrm{~Hz}, 1 \mathrm{H}), 1.24(\mathrm{t}, J=6.4 \mathrm{~Hz}, 3 \mathrm{H})$, $1.08(\mathrm{~d}, J=6.8 \mathrm{~Hz}, 3 \mathrm{H}), 0.95(\mathrm{~d}, J=6.8 \mathrm{~Hz}, 3 \mathrm{H}) \mathrm{ppm}$.

Ethyl 2-(3-Bromo-4-chlorobenzyl)-4-methyl-3-oxopentanoate (4ev). Compound was synthesized according to general procedure 2, using the following reagents: ethyl 4-methyl-3oxopentanoate 1e $(0.480 \mathrm{~mL}, 3.30 \mathrm{mmol}, 1.00$ equiv), 3-bromo-4chlorobenzyl bromide $3 \mathrm{v}(0.900 \mathrm{~g}, 3.16 \mathrm{mmol}, 0.958$ equiv), DIPEA $(1.05 \mathrm{~mL}, 6.00 \mathrm{mmol}, 1.82$ equiv), $\mathrm{LiCl}(0.130 \mathrm{~g}, 3.00 \mathrm{mmol}, 0.909$ equiv), $5 \mathrm{~mL}$ of dry THF. Yield: $34 \%(0.360 \mathrm{~g})$ as a yellow oil. ${ }^{1} \mathrm{H}$ NMR $\left(400 \mathrm{MHz}, \mathrm{CDCl}_{3}\right) \delta 7.44(\mathrm{~d}, J=2.0 \mathrm{~Hz}, 1 \mathrm{H}), 7.33(\mathrm{~d}, J=8.0$ $\mathrm{Hz}, 1 \mathrm{H}), 7.06(\mathrm{dd}, J=8.0,2.0 \mathrm{~Hz}, 1 \mathrm{H}), 4.15(\mathrm{qd}, J=7.2,1.6 \mathrm{~Hz}$, $2 \mathrm{H}), 3.88(\mathrm{t}, J=7.6 \mathrm{~Hz}, 1 \mathrm{H}), 3.14-3.04(\mathrm{~m}, 2 \mathrm{H}), 2.69$ (heptet, $J=$ $6.8 \mathrm{~Hz}, 1 \mathrm{H}), 1.22(\mathrm{t}, J=7.2 \mathrm{~Hz}, 3 \mathrm{H}), 1.08(\mathrm{~d}, J=6.8 \mathrm{~Hz}, 3 \mathrm{H}), 0.94$ $(\mathrm{d}, J=6.8 \mathrm{~Hz}, 3 \mathrm{H}) \mathrm{ppm}$.

Ethyl 2-(3-Chlorobenzyl)-3-oxoheptanoate (4fa). Compound was synthesized according to general procedure 2, using the following reagents: ethyl 3-oxoheptanoate $\mathbf{1 f}(0.47 \mathrm{~g}, 2.72 \mathrm{mmol}$, 1.00 equiv $)$, 3chlorobenzyl bromide $3 a(0.33 \mathrm{~mL}, 2.51 \mathrm{mmol}, 0.922$ equiv), DIPEA (1.05 mL, $6.00 \mathrm{mmol}, 2.21$ equiv), $\mathrm{LiCl}(0.130 \mathrm{~g}, 3.00 \mathrm{mmol}, 1.10$ equiv), $5 \mathrm{~mL}$ of dry THF. Yield: $67 \%(0.550 \mathrm{~g})$ as a colorless oil. ${ }^{1} \mathrm{H}$ NMR $\left(400 \mathrm{MHz}, \mathrm{CDCl}_{3}\right) \delta 7.20-7.15(\mathrm{~m}, 3 \mathrm{H}), 7.07-7.03(\mathrm{~m}, 1 \mathrm{H})$, 7.17-4.10 (m, 2H), $3.75(\mathrm{t}, J=7.6 \mathrm{~Hz}, 1 \mathrm{H}), 3.16-3.06(\mathrm{~m}, 2 \mathrm{H})$, $2.55(\mathrm{dt}, J=17.2,7.2 \mathrm{~Hz}, 1 \mathrm{H}), 2.35(\mathrm{dt}, J=17.6,7.2 \mathrm{~Hz}, 1 \mathrm{H}), 1.50$ (pentet, $J=7.6 \mathrm{~Hz}, 2 \mathrm{H}), 1.28-1.19(\mathrm{~m}, 5 \mathrm{H}), 0.85(\mathrm{t}, J=7.2 \mathrm{~Hz}, 3 \mathrm{H})$ ppm.

Ethyl 2-(3-Chlorobenzyl)-5-ethyl-3-oxoheptanoate (4ga). Compound was synthesized according to general procedure 2, using the following reagents: ethyl 5-ethyl-3-oxoheptanoate $1 \mathrm{~g}(0.600 \mathrm{~g}$, $3.00 \mathrm{mmol}$, 1.00 equiv), 3-chlorobenzyl bromide $3 \mathrm{a}(0.470 \mathrm{~mL}, 3.57$ mmol, 1.19 equiv), DIPEA ( $1.05 \mathrm{~mL}, 6.00 \mathrm{mmol}, 2.00$ equiv), $\mathrm{LiCl}$ $(0.130 \mathrm{~g}, 3.00 \mathrm{mmol}, 1.00$ equiv), $5 \mathrm{~mL}$ of dry THF. Yield: $31 \%$ $(0.300 \mathrm{~g})$ as a yellow oil. ${ }^{1} \mathrm{H}$ NMR $\left(400 \mathrm{MHz}, \mathrm{CDCl}_{3}\right) \delta 7.20-7.14$ $(\mathrm{m}, 3 \mathrm{H}), 7.06-7.05(\mathrm{~m}, 1 \mathrm{H}), 4.18-4.12(\mathrm{~m}, 2 \mathrm{H}), 3.75(\mathrm{t}, J=7.6 \mathrm{~Hz}$, $1 \mathrm{H}), 3.17-3.06(\mathrm{~m}, 2 \mathrm{H}), 2.45(\mathrm{dd}, \mathrm{J}=17.2,6.8 \mathrm{~Hz}, 1 \mathrm{H}), 2.29(\mathrm{dd}, J$ $=17.2,6.0 \mathrm{~Hz}, 1 \mathrm{H}), 1.76$ (heptet, $J=6.4 \mathrm{~Hz}, 1 \mathrm{H}), 1.30-1.17(\mathrm{~m}$, $7 \mathrm{H}), 0.78(\mathrm{t}, J=7.6 \mathrm{~Hz}, 6 \mathrm{H}) \mathrm{ppm}$.

Ethyl 2-(3-Chlorobenzyl)-3-oxooctanoate (4ha). Compound was synthesized according to general procedure 2 , using the following reagents: ethyl 3-oxooctanoate $1 \mathrm{~h}(0.560 \mathrm{~g}, 3.01 \mathrm{mmol}, 1.00$ equiv), 3-chlorobenzyl bromide $3 \mathrm{a}(0.470 \mathrm{~mL}, 3.57 \mathrm{mmol}, 1.18$ equiv), DIPEA (1.05 mL, $6.00 \mathrm{mmol}, 1.99$ equiv), $\mathrm{LiCl}(0.130 \mathrm{~g}, 3.00 \mathrm{mmol}$, 1.00 equiv), $5 \mathrm{~mL}$ of dry THF. Yield: $21 \%(0.197 \mathrm{~g})$ as a yellow oil. ${ }^{1} \mathrm{H}$ NMR $\left(400 \mathrm{MHz}, \mathrm{CDCl}_{3}\right) \delta 7.22-7.15(\mathrm{~m}, 3 \mathrm{H}), 7.07-7.04(\mathrm{~m}$, $1 \mathrm{H}), 4.15(\mathrm{q}, J=7.2 \mathrm{~Hz}, 2 \mathrm{H}), 3.75(\mathrm{t}, J=7.6 \mathrm{~Hz}, 1 \mathrm{H}), 3.17-3.07(\mathrm{~m}$, $2 \mathrm{H}), 2.54(\mathrm{dt}, J=17.2,7.2 \mathrm{~Hz}, 1 \mathrm{H}), 2.36(\mathrm{dt}, J=17.2,7.2 \mathrm{~Hz}, 1 \mathrm{H})$, 1.52 (pentet, $J=7.4 \mathrm{~Hz}, 2 \mathrm{H}), 1.31-1.13(\mathrm{~m}, 7 \mathrm{H}), 0.86(\mathrm{t}, J=7.2 \mathrm{~Hz}$, $3 \mathrm{H}) \mathrm{ppm}$.

Ethyl 2-(3-Chlorobenzyl)-3-cyclopentyl-3-oxopropanoate (4ia). ${ }^{23}$ Compound was synthesized according to general procedure 2, using the following reagents: ethyl 3-cyclopentyl-3-oxopropanoate li $(0.376 \mathrm{~g}, 2.04 \mathrm{mmol}, 1.00$ equiv), 3-chlorobenzyl bromide 3a ( $0.240 \mathrm{~mL}, 1.83 \mathrm{mmol}, 0.888$ equiv), DIPEA $(0.530 \mathrm{~mL}, 3.03 \mathrm{mmol}$, 1.47 equiv), $\mathrm{LiCl}(0.067 \mathrm{~g}, 1.57 \mathrm{mmol}, 0.772$ equiv), $5 \mathrm{~mL}$ of dry THF. Silica column chromatography $\left(20-50 \% \mathrm{CH}_{2} \mathrm{Cl}_{2} /\right.$ petroleum ether). Yield: $85 \%(0.483 \mathrm{~g})$ as a colorless oil. ${ }^{1} \mathrm{H}$ NMR $(400 \mathrm{MHz}$, $\left.\mathrm{CDCl}_{3}\right) \delta 7.20-7.15(\mathrm{~m}, 3 \mathrm{H}), 7.08-7.02(\mathrm{~m}, 1 \mathrm{H}), 4.13(\mathrm{q}, J=7.2$ 
$\mathrm{Hz}, 2 \mathrm{H}), 3.85(\mathrm{t}, J=7.6 \mathrm{~Hz}, 1 \mathrm{H}), 3.15-3.05(\mathrm{~m}, 2 \mathrm{H}), 2.94$ (pentet, $J$ $=8.0 \mathrm{~Hz}, 1 \mathrm{H}), 1.87-1.35(\mathrm{~m}, 8 \mathrm{H}), 1.20(\mathrm{t}, J=7.2 \mathrm{~Hz}, 3 \mathrm{H}) \mathrm{ppm}$.

Ethyl 2-(3-Chlorobenzyl)-3-oxononanoate (4ja). Compound was synthesized according to general procedure 2 , using the following reagents: ethyl 3-oxononanoate $1 \mathbf{1 j}(0.601 \mathrm{~g}, 3.00 \mathrm{mmol}, 1.00$ equiv), 3-chlorobenzyl bromide $3 \mathrm{a}(0.325 \mathrm{~mL}, 2.48 \mathrm{mmol}, 0.825$ equiv), DIPEA ( $1.05 \mathrm{~mL}, 6.00 \mathrm{mmol}, 2.00$ equiv), $\mathrm{LiCl}(0.130 \mathrm{~g}$, $3.00 \mathrm{mmol}$, 1.00 equiv), $5 \mathrm{~mL}$ of dry THF. Yield: $97 \%(0.780 \mathrm{~g})$ as a colorless oil. ${ }^{1} \mathrm{H}$ NMR (400 MHz, $\mathrm{CDCl}_{3}$ ) $\delta 7.20-7.15(\mathrm{~m}, 3 \mathrm{H}), 7.07-7.01(\mathrm{~m}$, $1 \mathrm{H}), 4.14(\mathrm{q}, J=6.8 \mathrm{~Hz}, 2 \mathrm{H}), 3.75(\mathrm{t}, J=7.6 \mathrm{~Hz}, 1 \mathrm{H}), 3.17-3.06(\mathrm{~m}$, $2 \mathrm{H}), 2.53(\mathrm{dt}, \mathrm{J}=17.6,7.2 \mathrm{~Hz}, 1 \mathrm{H}), 2.35(\mathrm{dt}, J=17.6,7.2 \mathrm{~Hz}, 1 \mathrm{H})$, 1.50 (pentet, $J=7.2 \mathrm{~Hz}, 2 \mathrm{H}), 1.30-1.15(\mathrm{~m}, 9 \mathrm{H}), 0.85(\mathrm{t}, J=7.2 \mathrm{~Hz}$ $3 \mathrm{H}) \mathrm{ppm}$.

Ethyl 2-(3-Chlorobenzyl)-3-oxodecanoate (4ka). Compound was synthesized according to general procedure 2 , using the following reagents: ethyl 3-oxodecanoate $1 \mathrm{k}(0.650 \mathrm{~g}, 3.03 \mathrm{mmol}, 1.00$ equiv), 3-chlorobenzyl bromide 3a $(0.475 \mathrm{~mL}, 3.60 \mathrm{mmol}, 1.20$ equiv), DIPEA ( $1.05 \mathrm{~mL}, 6.00 \mathrm{mmol}, 2.00$ equiv), $\mathrm{LiCl}(0.128 \mathrm{~g}, 3.00 \mathrm{mmol}$, 1.00 equiv), $5 \mathrm{~mL}$ of dry THF. Yield: $50 \%(0.511 \mathrm{~g})$ as a yellow oil. ${ }^{1} \mathrm{H}$ NMR $\left(400 \mathrm{MHz}, \mathrm{CDCl}_{3}\right) \delta 7.21-7.16(\mathrm{~m}, 3 \mathrm{H}), 7.07-7.04(\mathrm{~m}$, $1 \mathrm{H}), 4.15(\mathrm{q}, J=7.2 \mathrm{~Hz}, 2 \mathrm{H}), 3.75(\mathrm{t}, J=7.6 \mathrm{~Hz}, 1 \mathrm{H}), 3.18-3.06(\mathrm{~m}$, $2 \mathrm{H}), 2.54(\mathrm{dt}, J=17.6,7.2 \mathrm{~Hz}, 1 \mathrm{H}), 2.36(\mathrm{dt}, J=17.6,7.6 \mathrm{~Hz}, 1 \mathrm{H})$, 1.51 (pentet, $J=6.8 \mathrm{~Hz}, 2 \mathrm{H}), 1.31-1.17(\mathrm{~m}, 11 \mathrm{H}), 0.87(\mathrm{t}, J=6.8$ $\mathrm{Hz}, 3 \mathrm{H}) \mathrm{ppm}$.

Ethyl 2-(3-Chlorobenzyl)-3-oxo-3-phenylpropanoate (4la). ${ }^{23}$ Compound was synthesized according to general procedure 2, using the following reagents: ethyl 3-oxo-3-phenylpropanoate 11 (0.498 mL, $2.92 \mathrm{mmol}, 1.20$ equiv), 3-chlorobenzyl bromide $3 \mathrm{a}$ (0.320 mL, $2.43 \mathrm{mmol}, 1.00$ equiv), DIPEA (0.847 mL, 4.86, 2.00 equiv), $\mathrm{LiCl}$ ( $103 \mathrm{mg} ; 2.43 \mathrm{mmol}, 1.00$ equiv), $5 \mathrm{~mL}$ of dry THF. Yield: $85 \%(686 \mathrm{mg})$ as a colorless oil. ${ }^{1} \mathrm{H}$ NMR $\left(400 \mathrm{MHz}, \mathrm{CDCl}_{3}\right)$ : $\delta 7.92(\mathrm{dd}, J=8.0,0.8,2 \mathrm{H}), 7.46(\mathrm{td}, J=7.6,1.2 \mathrm{~Hz}, 1 \mathrm{H}), 7.35(\mathrm{t}, J=$ $7.6 \mathrm{~Hz}, 2 \mathrm{H}), 7.20(\mathrm{~s}, 1 \mathrm{H}), 7.10-7.05(\mathrm{~m}, 3 \mathrm{H}), 4.62(\mathrm{t}, J=7.2 \mathrm{~Hz}$, $1 \mathrm{H}), 4.05-3.95(\mathrm{~m}, 2 \mathrm{H}), 3.31-3.20(\mathrm{~m}, 2 \mathrm{H}), 1.01(\mathrm{t}, J=7.2,0.8 \mathrm{~Hz}$, $3 \mathrm{H}) \mathrm{ppm}$.

Ethyl 2-(3-Chlorobenzyl)-3-oxo-3-(p-tolyl)propanoate (4ma). Compound was synthesized according to general procedure 2 , using the following reagents: ethyl 3-oxo-3-( $p$-tolyl)propanoate $\mathbf{1 m}$ (2.30 g, $11.15 \mathrm{mmol}, 1.00$ equiv), 3-chlorobenzyl bromide 3a (2.29 $\mathrm{mL}, 11.15 \mathrm{mmol}, 1.00$ equiv), DIPEA (3.88 mL, $22.3 \mathrm{mmol}, 2.00$ equiv), $\mathrm{LiCl}$ ( $473 \mathrm{mg} ; 11.15 \mathrm{mmol}, 1.00$ equiv), $30 \mathrm{~mL}$ of dry THF. Yield: $86 \%(3.18 \mathrm{~g})$ as a white solid. ${ }^{1} \mathrm{H}$ NMR $\left(400 \mathrm{MHz}, \mathrm{CDCl}_{3}\right): \delta$ $7.87(\mathrm{~d}, J=8.0 \mathrm{~Hz}, 2 \mathrm{H}), 7.28-7.22(\mathrm{~m}, 3 \mathrm{H}), 7.19-7.14(\mathrm{~m}, 2 \mathrm{H})$, $7.12-7.09(\mathrm{~m}, 1 \mathrm{H}), 4.57(\mathrm{t}, J=7.6 \mathrm{~Hz}, 1 \mathrm{H}), 4.13-4.05(\mathrm{~m}, 2 \mathrm{H})$, $3.33-3.23(\mathrm{~m}, 2 \mathrm{H}), 2.41(\mathrm{~s}, 3 \mathrm{H}), 1.12(\mathrm{t}, J=7.2 \mathrm{~Hz}, 3 \mathrm{H}) \mathrm{ppm}$

Ethyl 2-(3-Chlorobenzyl)-3-oxo-5-phenylpentanoate (4na). Compound was synthesized according to general procedure 2, using the following reagents: ethyl 3-oxo-5-phenylpentanoate $1 \mathrm{n}(0.661 \mathrm{~g}$, $3.00 \mathrm{mmol}, 1.00$ equiv), 3-chlorobenzyl bromide $3 \mathrm{a}(0.475 \mathrm{~mL}, 3.65$ mmol, 1.20 equiv), DIPEA ( $1.05 \mathrm{~mL}, 6.00 \mathrm{mmol}, 2.00$ equiv), $\mathrm{LiCl}$ $(0.128 \mathrm{~g}, 3.00 \mathrm{mmol}, 1.00$ equiv), $5 \mathrm{~mL}$ of dry THF. Yield: $67 \%$ $(0.690 \mathrm{~g})$ as a white solid. ${ }^{1} \mathrm{H}$ NMR $\left(400 \mathrm{MHz}, \mathrm{CDCl}_{3}\right) \delta 7.32-7.26$ $(\mathrm{m}, 2 \mathrm{H}), 7.24-7.19(\mathrm{~m}, 3 \mathrm{H}), 7.16(\mathrm{t}, J=7.2 \mathrm{~Hz}, 3 \mathrm{H}), 4.13(\mathrm{q}, J=7.2$ $\mathrm{Hz}, 2 \mathrm{H}), 3.75(\mathrm{t}, J=7.6 \mathrm{~Hz}, 1 \mathrm{H}), 3.13(\mathrm{~d}, J=7.6 \mathrm{~Hz}, 2 \mathrm{H}), 2.99-2.85$ $(\mathrm{m}, 3 \mathrm{H}), 2.75-2.67(\mathrm{~m}, 1 \mathrm{H}), 1.20(\mathrm{t}, J=7.2 \mathrm{~Hz}, 3 \mathrm{H}) \mathrm{ppm}$.

Procedure for the Synthesis of 6-(3-Chlorobenzyl)-5cyclopropyl[1,2,4]triazolo[1,5-a]pyrimidin-7(4H)-one (6). ${ }^{23,24}$ In a sealed microwave tube 3 -amino-1,2,4-triazole $5 \mathrm{a}(66 \mathrm{mg}, 0.78$ mmol, 1.1 equiv), $4 \mathbf{b a}\left(200 \mathrm{mg}, 0.71 \mathrm{mmol}, 1.00\right.$ equiv), and $\mathrm{H}_{3} \mathrm{PO}_{4}$ ( $96 \mu \mathrm{L}, 1.42 \mathrm{mmol}, 2.00$ equiv) were heated at $170{ }^{\circ} \mathrm{C}$ in $1 \mathrm{~mL}$ of $\mathrm{EtOH}$ in the microwave for $10 \mathrm{~h}$. The reaction mixture was poured in water $(30 \mathrm{~mL})$, the $\mathrm{pH}$ was adjusted to $\mathrm{pH}=12(1 \mathrm{M} \mathrm{NaOH}$ aq $)$, and the organics were extracted with EtOAc $(3 \times 30 \mathrm{~mL})$. The combined extracts were dried over $\mathrm{MgSO}_{4}$ and the solvents evaporated in vacuo, resulting in $165 \mathrm{mg}$ of crude mixture. The pure product was obtained by column chromatography $\left(5 \% \mathrm{CH}_{3} \mathrm{OH}\right.$ in $\mathrm{CH}_{2} \mathrm{Cl}_{2}$ ) followed by prep HPLC gradient $10-90 \% \mathrm{CH}_{3} \mathrm{CN} /$ water $+0.1 \%$ TFA yielding $4 \%(9 \mathrm{mg})$ as a white solid. ${ }^{1} \mathrm{H}$ NMR $(400 \mathrm{MHz}$, $\left.\mathrm{CDCl}_{3}\right): \delta 8.14(\mathrm{~s}, 1 \mathrm{H}), 7.28-7.25(\mathrm{~m}, 1 \mathrm{H}), 7.22-7.15(\mathrm{~m}, 3 \mathrm{H})$, 7.17-7.08 (m, 3H), $4.16(\mathrm{~s}, 2 \mathrm{H}), 2.22-2.13(\mathrm{~m}, 1 \mathrm{H}), 1.36-1.30(\mathrm{~m}$,
$2 \mathrm{H}), \quad 1.20-1.15(\mathrm{~m}, 2 \mathrm{H}) \mathrm{ppm}$. LC-MS (ESI) $\mathrm{m} / \mathrm{z}$ calcd for $\mathrm{C}_{15} \mathrm{H}_{13} \mathrm{ClN}_{4} \mathrm{O}[\mathrm{M}+\mathrm{H}]^{+}$301.09, found 301.1. HPLC: $6.566 \mathrm{~min}$, purity $97 \%$.

Procedure for the Synthesis of 6-(3-Chlorobenzyl)-5-cyclopropyl-2-methyl[1,2,4]triazolo[1,5-a]pyrimidin-7(4H)-one (7). In a sealed microwave tube 3-amino-5-methyl-1,2,4-triazole $\mathbf{5 b}$ (126 $\mathrm{mg}, 1.28 \mathrm{mmol}, 1.2$ equiv), $4 \mathrm{ba}(300 \mathrm{mg}, 1.07 \mathrm{mmol}, 1.0$ equiv), and $p$-toluenesulfonic acid monohydrate $(102 \mathrm{mg}, 0.53 \mathrm{mmol}, 0.5$ equiv) were heated for $30 \mathrm{~min}$ at $180{ }^{\circ} \mathrm{C}$ in the microwave. As visualized by TLC, 4ba was consumed and mainly one product was formed ( $\mathrm{Rf} 0.5$ in $5 \% \mathrm{CH}_{3} \mathrm{OH}$ in $\mathrm{CH}_{2} \mathrm{Cl}_{2}$ ). The crude product was purified by column chromatography $\left(3 \% \mathrm{CH}_{3} \mathrm{OH}\right.$ in $\mathrm{CH}_{2} \mathrm{Cl}_{2}$ ) yielding $31 \%$ (96 $\mathrm{mg}$ ) as a white solid. ${ }^{1} \mathrm{H}$ NMR (400 MHz, $\mathrm{CDCl}_{3}+$ drop MeOD): $\delta$ $7.23(\mathrm{~s}, 1 \mathrm{H}), 7.21-7.13(\mathrm{~m}, 3 \mathrm{H}), 6.26(\mathrm{br} \mathrm{s}, 2 \mathrm{H}), 4.11(\mathrm{~s}, 2 \mathrm{H}), 2.47$ $(\mathrm{s}, 2 \mathrm{H}), 2.05-1.96(\mathrm{~m}, 1 \mathrm{H}), 1.14-1.07(\mathrm{~m}, 2 \mathrm{H}), 1.05-1.01(\mathrm{~m}, 2 \mathrm{H})$ ppm. LC-MS (ESI) $m / z$ calcd for $\mathrm{C}_{16} \mathrm{H}_{15} \mathrm{ClN}_{4} \mathrm{O}[\mathrm{M}+\mathrm{H}]^{+} 315.10$, found 315.1. HPLC: $6.826 \mathrm{~min}$, purity $96 \%$.

General Procedure 3. Triazolopyrimidinones 8-43. ${ }^{23}$ The synthesis of compounds 8-43 was according to the following procedure: In a microwave tube a mixture of the corresponding benzylated $\beta$-keto ester $\mathbf{4 a a}-\mathbf{n a}, \mathbf{4 b b}-\mathbf{b q}, \mathbf{4 e q}-\mathbf{e v}$ ( 1.00 equiv), triazole 5c (2.00 equiv) and 1-butyl-3-methylimidazolium hexafluorophosphate (BMIM-PF6, $1 \mathrm{~mL}$ or 6.00 equiv) was heated at $200{ }^{\circ} \mathrm{C}$ in a microwave reactor for an hour. Afterward, the reaction was allowed to cool to room temperature and stirred in a mixture of $\mathrm{CH}_{2} \mathrm{Cl}_{2}(30 \mathrm{~mL}), \mathrm{H}_{2} \mathrm{O}(10 \mathrm{~mL})$, and $5-10 \%$ aqueous citric acid (1 $\mathrm{mL}$ ) for 20-30 min. The resulting mixture was filtered over a glass filter, and the residue was washed with hot methanol. Finally, the precipitate was collected and dried in vacuo to yield the pure compounds.

2-Amino-6-(3-chlorobenzyl)-5-cyclopropyl[1,2,4]triazolo$[1,5-a]$ pyrimidin-7(4H)-one (8). ${ }^{23}$ Compound was synthesized according to general procedure 3 , using the following reagents: 3,5 diamino-4H-1,2,4-triazole $5 \mathrm{c}$ ( $216 \mathrm{mg}, 2.18 \mathrm{mmol}, 2.00$ equiv), $4 \mathrm{ba}$ (306 mg, $1.09 \mathrm{mmol}, 1.00$ equiv), and BMIM-PF6 (1.35 mL, 6.54 mmol, 6.00 equiv). Yield: $36 \%(125 \mathrm{mg})$ as a white solid. ${ }^{1} \mathrm{H}$ NMR (400 MHz, DMSO): $\delta 12.16$ (br s, $1 \mathrm{H}), 7.35-7.24(\mathrm{~m}, 2 \mathrm{H}), 7.24-$ $7.14(\mathrm{~m}, 2 \mathrm{H}), 6.24(\mathrm{br} \mathrm{s}, 2 \mathrm{H}), 3.96(\mathrm{~s}, 2 \mathrm{H}), 2.14-2.01(\mathrm{~m}, 1 \mathrm{H})$, 1.07-0.94 (m, 2H), 0.94-0.81 (m, 2H) ppm. LC-MS (ESI) $\mathrm{m} / z$ calcd for $\mathrm{C}_{15} \mathrm{H}_{14} \mathrm{ClN}_{5} \mathrm{O}[\mathrm{M}+\mathrm{H}]^{+} 316.10$, found 316.13. HPLC: $6.350 \mathrm{~min}$, purity $98 \%$.

2-Amino-6-benzyl-5-cyclopropyl[ $1,2,4]$ triazolo[ $1,5-a]-$ pyrimidin-7(4H)-one (9). Compound was synthesized according to general procedure 3 , using the following reagents: 3,5-diamino- $4 \mathrm{H}$ 1,2,4-triazole $5 \mathrm{c}(276 \mathrm{mg}, 2.84 \mathrm{mmol}, 2.00$ equiv), $4 \mathrm{bb}(350 \mathrm{mg}, 1.42$ mmol, 1.00 equiv) and BMIM-PF6 ( $1.75 \mathrm{~mL}, 8.52 \mathrm{mmol}, 6.00$ equiv). Yield: $26 \%(105 \mathrm{mg})$ as a white solid. ${ }^{1} \mathrm{H}$ NMR (400 MHz, DMSO): $\delta 12.11(\mathrm{br} \mathrm{s}, 1 \mathrm{H}), 7.26-7.20(\mathrm{~m}, 4 \mathrm{H}), 7.17-7.10(\mathrm{~m}, 1 \mathrm{H}), 6.20(\mathrm{br}$ $\mathrm{s}, 2 \mathrm{H}), 3.96(\mathrm{~s}, 2 \mathrm{H}), 2.10-2.03(\mathrm{~m}, 1 \mathrm{H}), 1.04-0.95(\mathrm{~m}, 2 \mathrm{H}), 0.94-$ $0.88(\mathrm{~m}, 2 \mathrm{H}) \mathrm{ppm}$. LC-MS (ESI) $\mathrm{m} / z$ calcd for $\mathrm{C}_{15} \mathrm{H}_{15} \mathrm{~N}_{5} \mathrm{O}[\mathrm{M}+$ $\mathrm{H}]^{+} 282.14$, found 282.13 . HPLC: $5.655 \mathrm{~min}$, purity $97 \%$.

2-Amino-5-cyclopropyl-6-(2-methylbenzyl)[1,2,4]triazolo$[1,5-a]$ pyrimidin-7 $(4 H)$-one (10). Compound was synthesized according to general procedure 3 , using the following reagents: 3,5 diamino-4H-1,2,4-triazole $5 \mathrm{c}$ ( $190 \mathrm{mg}, 1.96 \mathrm{mmol}, 2.00$ equiv), $4 \mathrm{bc}$ (255 mg, $0.98 \mathrm{mmol}, 1.00$ equiv), and BMIM-PF6 (1.21 mL, 5.88 mmol, 6.00 equiv). Yield: $32 \%(93 \mathrm{mg})$ as a white solid. ${ }^{1} \mathrm{H}$ NMR (400 MHz, DMSO): $\delta 12.17$ (br s, $1 \mathrm{H}), 7.15(\mathrm{~d}, J=6.8 \mathrm{~Hz}, 1 \mathrm{H})$, $7.08-6.99(\mathrm{~m}, 2 \mathrm{H}), 6.81(\mathrm{~d}, J=6.8 \mathrm{~Hz}, 1 \mathrm{H}), 6.21(\mathrm{br} \mathrm{s}, 2 \mathrm{H}), 3.86(\mathrm{~s}$, $2 \mathrm{H}), 2.36(\mathrm{~s}, 3 \mathrm{H}), 1.90-1.81(\mathrm{~m}, 1 \mathrm{H}), 1.04-0.94(\mathrm{~m}, 2 \mathrm{H}), 0.88-$ $0.81(\mathrm{~m}, 2 \mathrm{H})$ ppm. LC-MS (ESI) $\mathrm{m} / z$ calcd for $\mathrm{C}_{16} \mathrm{H}_{17} \mathrm{~N}_{5} \mathrm{O}[\mathrm{M}+$ $\mathrm{H}]^{+} 296.15$, found 296.13 . HPLC: $6.074 \mathrm{~min}$, purity $98 \%$.

2-Amino-6-(2-chlorobenzyl)-5-cyclopropyl[1,2,4]triazolo$[1,5-a]$ pyrimidin-7 $(4 H)$-one $(11)$. Compound was synthesized according to general procedure 3 , using the following reagents: 3,5 diamino-4H-1,2,4-triazole $5 \mathrm{c}$ ( $173 \mathrm{mg}, 1.78 \mathrm{mmol}, 2.00$ equiv), 4bd (250 mg, $0.89 \mathrm{mmol}, 1.00$ equiv), and BMIM-PF6 (1.01 mL, 5.34 mmol, 6.00 equiv). Yield: $37 \%(104 \mathrm{mg})$ as a white solid. ${ }^{1} \mathrm{H}$ NMR (400 MHz, DMSO): $\delta 12.14$ (br s, $1 \mathrm{H}$ ), 7.47-7.42 (m, 1H), 7.24$7.17(\mathrm{~m}, 2 \mathrm{H}), 7.01-6.96(\mathrm{~m}, 1 \mathrm{H}), 6.20($ br s, $2 \mathrm{H}), 4.00(\mathrm{~s}, 2 \mathrm{H})$, 
$1.90-1.80(\mathrm{~m}, 1 \mathrm{H}), 0.99-0.93(\mathrm{~m}, 2 \mathrm{H}), 0.89-0.80(\mathrm{~m}, 2 \mathrm{H}) \mathrm{ppm}$. LC-MS (ESI) $m / z$ calcd for $\mathrm{C}_{15} \mathrm{H}_{14} \mathrm{ClN}_{5} \mathrm{O}[\mathrm{M}+\mathrm{H}]^{+} 316.10$, found 316.13. HPLC: $6.411 \mathrm{~min}$, purity $95 \%$.

2-Amino-5-cyclopropyl-6-(2-methoxybenzyl) [1,2,4]triazolo[1,5-a]pyrimidin-7(4H)-one (12). Compound was synthesized according to general procedure 3 , using the following reagents: 3,5diamino-4H-1,2,4-triazole $5 \mathrm{c}(130 \mathrm{mg}, 1.34 \mathrm{mmol}, 2.00$ equiv), 4be ( $185 \mathrm{mg}, 0.67 \mathrm{mmol}, 1.00$ equiv), and BMIM-PF6 (0.83 mL, 4.02 mmol, 6.00 equiv). Yield: $43 \%(89 \mathrm{mg})$ as a white solid. ${ }^{1} \mathrm{H}$ NMR (400 MHz, DMSO): $\delta 12.11(\mathrm{br} \mathrm{s}, 1 \mathrm{H}), 7.15(\mathrm{t}, J=6.0 \mathrm{~Hz}, 1 \mathrm{H}), 6.95$ $(\mathrm{d}, J=6.4 \mathrm{~Hz}, 1 \mathrm{H}), 6.86(\mathrm{~d}, J=5.6 \mathrm{~Hz}, 1 \mathrm{H}), 6.78(\mathrm{t}, J=5.6 \mathrm{~Hz}, 1 \mathrm{H})$, 6.18 (br s, $2 \mathrm{H}), 3.86(\mathrm{~s}, 2 \mathrm{H}), 3.83(\mathrm{~s}, 3 \mathrm{H}), 1.98-1.86(\mathrm{~m}, 1 \mathrm{H}), 1.03-$ $0.91(\mathrm{~m}, 2 \mathrm{H}), 0.90-0.79(\mathrm{~m}, 2 \mathrm{H}) \mathrm{ppm}$. LC-MS (ESI) $\mathrm{m} / \mathrm{z}$ calcd for $\mathrm{C}_{16} \mathrm{H}_{17} \mathrm{~N}_{5} \mathrm{O} 2[\mathrm{M}+\mathrm{H}]^{+}$312.15, found 312.2. HPLC: $5.832 \mathrm{~min}$, purity $98 \%$.

2-Amino-5-cyclopropyl-6-(3-methylbenzyl)[1,2,4]triazolo[1,5-a]pyrimidin-7(4H)-one (13). Compound was synthesized according to general procedure 3 , using the following reagents: 3,5diamino-4H-1,2,4-triazole $5 \mathrm{c}(216 \mathrm{mg}, 2.22 \mathrm{mmol}, 2.00$ equiv), $4 \mathbf{b f}$ (289 mg, $1.11 \mathrm{mmol}, 1.00$ equiv), and BMIM-PF6 (1.37 mL, 6.66 mmol, 6.00 equiv). Yield: $35 \%(114 \mathrm{mg})$ as a white solid. ${ }^{1} \mathrm{H}$ NMR (400 MHz, DMSO): $\delta 11.98$ (br s, $1 \mathrm{H}), 7.12(\mathrm{t}, J=7.6 \mathrm{~Hz}, 1 \mathrm{H}), 7.04$ $(\mathrm{s}, 1 \mathrm{H}), 7.01(\mathrm{~d}, J=7.2 \mathrm{~Hz}, 1 \mathrm{H}), 6.95(\mathrm{~d}, J=7.2 \mathrm{~Hz}, 1 \mathrm{H}), 6.17(\mathrm{br} \mathrm{s}$, $2 \mathrm{H}), 3.91(\mathrm{~s}, 2 \mathrm{H}), 2.23(\mathrm{~s}, 3 \mathrm{H}), 2.10-2.00(\mathrm{~m}, 1 \mathrm{H}), 1.04-0.94(\mathrm{~m}$, $2 \mathrm{H}), 0.94-0.83(\mathrm{~m}, 2 \mathrm{H}) \mathrm{ppm}$. LC-MS (ESI) $\mathrm{m} / z$ calcd for $\mathrm{C}_{16} \mathrm{H}_{17} \mathrm{~N}_{5} \mathrm{O}[\mathrm{M}+\mathrm{H}]^{+}$296.15, found 296.13. HPLC: $6.154 \mathrm{~min}$, purity $97 \%$.

2-Amino-5-cyclopropyl-6-(3-fluorobenzyl) $[1,2,4]$ triazolo[1,5-a]pyrimidin-7(4H)-one (14). Compound was synthesized according to general procedure 3 , using the following reagents: $3,5-$ diamino-4H-1,2,4-triazole $5 \mathrm{c}(190 \mathrm{mg}, 1.92 \mathrm{mmol}, 1.45$ equiv), $4 \mathrm{bg}$ (350 mg, $1.32 \mathrm{mmol}, 1.00$ equiv), and BMIM-PF6 (1.14 mL, 5.54 mmol, 4.19 equiv). Yield: $15 \%(61 \mathrm{mg})$ as a white solid. ${ }^{1} \mathrm{H}$ NMR (400 MHz, DMSO): $\delta 7.40-7.20(\mathrm{~m}, 1 \mathrm{H}), 7.16-6.85(\mathrm{~m}, 3 \mathrm{H}), 5.81$ (br s, $2 \mathrm{H}), 4.01(\mathrm{~s}, 2 \mathrm{H}), 2.12-1.95(\mathrm{~m}, 1 \mathrm{H}), 1.10-0.85(\mathrm{~m}, 4 \mathrm{H})$ ppm. LC-MS (ESI) $m / z$ calcd for $\mathrm{C}_{15} \mathrm{H}_{14} \mathrm{FN}_{5} \mathrm{O}[\mathrm{M}+\mathrm{H}]^{+} 300.13$, found 300.1. HPLC: 5.812 min, purity $97 \%$.

2-Amino-6-(3-bromobenzyl)-5-cyclopropyl[1,2,4]triazolo$[1,5-a]$ pyrimidin-7 $(4 H)$-one (15). Compound was synthesized according to general procedure 3 , using the following reagents: 3,5diamino-4H-1,2,4-triazole $5 \mathrm{c}$ ( $169 \mathrm{mg}, 1.74 \mathrm{mmol}, 2.00$ equiv), 4bh (283 mg, $0.87 \mathrm{mmol}, 1.00$ equiv), and BMIM-PF6 (1.07 mL, 5.22 mmol, 6.00 equiv). Yield: $43 \%(135 \mathrm{mg})$ as a white solid. ${ }^{1} \mathrm{H}$ NMR (400 MHz, DMSO): $\delta 12.21$ (br s, $1 \mathrm{H}), 7.43(\mathrm{~s}, 1 \mathrm{H}), 7.34(\mathrm{~d}, J=7.2$ $\mathrm{Hz}, 1 \mathrm{H}), 7.25(\mathrm{~d}, J=7.6 \mathrm{~Hz}, 1 \mathrm{H}), 7.20(\mathrm{t}, J=7.6 \mathrm{~Hz}, 1 \mathrm{H}), 6.26(\mathrm{br} \mathrm{s}$, $2 \mathrm{H}), 3.96(\mathrm{~s}, 2 \mathrm{H}), 2.12-2.04(\mathrm{~m}, 1 \mathrm{H}), 1.04-0.94(\mathrm{~m}, 2 \mathrm{H}), 0.94-$ $0.85(\mathrm{~m}, 2 \mathrm{H})$ ppm. LC-MS (ESI) $m / z$ calcd for $\mathrm{C}_{15} \mathrm{H}_{14} \mathrm{BrN}_{5} \mathrm{O}[\mathrm{M}+$ $\mathrm{H}]^{+} 360.05$, found 360.2 . HPLC: $6.529 \mathrm{~min}$, purity $99 \%$.

2-Amino-5-cyclopropyl-6-(3-iodobenzyl)[1,2,4]triazolo[1,5a]pyrimidin-7(4H)-one (16). Compound was synthesized according to general procedure 3 , using the following reagents: 3,5-diamino- $4 \mathrm{H}$ 1,2,4-triazole 5c (190 mg, $1.92 \mathrm{mmol}, 2.32$ equiv), 4bi $(320 \mathrm{mg}, 0.86$ mmol, 1.00 equiv), and BMIM-PF6 (1.14 mL, $4.25 \mathrm{mmol}, 6.00$ equiv). Yield: $26 \%(92 \mathrm{mg})$ as a white solid. ${ }^{1} \mathrm{H}$ NMR $(400 \mathrm{MHz}$, DMSO): $\delta 12.18($ br s, $1 \mathrm{H}), 7.62(\mathrm{~s}, 4 \mathrm{H}), 7.51(\mathrm{~d}, J=7.6 \mathrm{~Hz}, 1 \mathrm{H})$, $7.25(\mathrm{~d}, J=7.6 \mathrm{~Hz}, 1 \mathrm{H}), 7.05(\mathrm{t}, J=7.6 \mathrm{~Hz}, 1 \mathrm{H}), 6.22($ br s, $2 \mathrm{H})$, $3.92(\mathrm{~s}, 2 \mathrm{H}), 2.12-2.07(\mathrm{~m}, 1 \mathrm{H}), 1.01-0.94(\mathrm{~m}, 2 \mathrm{H}), 0.93-0.86(\mathrm{~m}$, $2 \mathrm{H}$ ). LC-MS (ESI) $\mathrm{m} / z$ calcd for $\mathrm{C}_{15} \mathrm{H}_{14} \mathrm{IN}_{5} \mathrm{O}[\mathrm{M}+\mathrm{H}]^{+}$408.03, found 408.1. HPLC: $7.042 \mathrm{~min}$, purity $96 \%$.

2-Amino-5-cyclopropyl-6-(3-methoxybenzyl)[1,2,4]triazolo[1,5-a]pyrimidin-7(4H)-one (17). Compound was synthesized according to general procedure 3 , using the following reagents: $3,5-$ diamino-4H-1,2,4-triazole $5 \mathrm{c}$ ( $146 \mathrm{mg}, 1.50 \mathrm{mmol}, 2.00$ equiv), $4 \mathbf{b j}$ (207 mg, $0.75 \mathrm{mmol}, 1.00$ equiv), BMIM-PF6 (0.93 mL, $4.50 \mathrm{mmol}$, 6.00 equiv). Yield: $21 \%(48 \mathrm{mg})$ as a white solid. ${ }^{1} \mathrm{H}$ NMR (400 $\mathrm{MHz}, \mathrm{DMSO}): \delta 11.94($ br s, $1 \mathrm{H}), 7.15(\mathrm{t}, J=8.0 \mathrm{~Hz}, 1 \mathrm{H}), 6.82-$ $6.77(\mathrm{~m}, 2 \mathrm{H}), 6.72(\mathrm{~d}, J=7.6 \mathrm{~Hz}, 1 \mathrm{H}), 6.16(\mathrm{br} \mathrm{s}, 2 \mathrm{H}), 3.93(\mathrm{~s}, 2 \mathrm{H})$, $3.69(\mathrm{~s}, 3 \mathrm{H}), 2.11-2.03(\mathrm{~m}, 1 \mathrm{H}), 1.04-0.96(\mathrm{~m}, 2 \mathrm{H}), 0.96-0.85(\mathrm{~m}$, $2 \mathrm{H})$ ppm. LC-MS (ESI) $m / z$ calcd for $\mathrm{C}_{16} \mathrm{H}_{17} \mathrm{~N}_{5} \mathrm{O}_{2}[\mathrm{M}+\mathrm{H}]^{+}$ 312.15 , found 312.13 . HPLC: $5.675 \mathrm{~min}$, purity $96 \%$.
2-Amino-5-cyclopropyl-6-(3-(trifluoromethyl)benzyl)[1,2,4]triazolo[1,5-a]pyrimidin-7(4H)-one (18). Compound was synthesized according to general procedure 3 , using the following reagents: 3,5-diamino-4H-1,2,4-triazole $5 c$ ( $150 \mathrm{mg}, 1.54 \mathrm{mmol}, 2.00$ equiv), 4bk ( $242 \mathrm{mg}, 0.77 \mathrm{mmol}, 1.00$ equiv), and BMIM-PF6 (0.95 mL, 4.62 mmol, 6.00 equiv). Yield $6 \%(17 \mathrm{mg})$ as a white solid. ${ }^{1} \mathrm{H}$ NMR (400 $\mathrm{MHz}, \mathrm{DMSO}): \delta 12.18(\mathrm{br} \mathrm{s}, 1 \mathrm{H}), 7.61(\mathrm{~s}, 1 \mathrm{H}), 7.57-7.46(\mathrm{~m}, 3 \mathrm{H})$, $6.24(\mathrm{br} \mathrm{s}, 2 \mathrm{H}), 4.06(\mathrm{~s}, 2 \mathrm{H}), 2.17-2.08(\mathrm{~m}, 1 \mathrm{H}), 1.03-0.95(\mathrm{~m}$, $2 \mathrm{H}), 0.94-0.86(\mathrm{~m}, 2 \mathrm{H}) \mathrm{ppm}$. LC-MS (ESI) $\mathrm{m} / z$ calcd for $\mathrm{C}_{16} \mathrm{H}_{14} \mathrm{~F}_{3} \mathrm{~N}_{5} \mathrm{O}[\mathrm{M}+\mathrm{H}]^{+}$350.13, found 350.27. HPLC: $6.727 \mathrm{~min}$, purity $97 \%$.

2-Amino-5-cyclopropyl-6-(4-methylbenzyl)[1,2,4]triazolo[1,5-a]pyrimidin-7(4H)-one (19). Compound was synthesized according to general procedure 3 , using the following reagents: 3,5diamino-4H-1,2,4-triazole $5 \mathbf{c}$ (197 mg, $2.03 \mathrm{mmol}, 2.00$ equiv), $4 \mathbf{b l}$ (266 mg, $1.02 \mathrm{mmol}, 1.00$ equiv), and BMIM-PF6 (1.25 mL, 6.09 mmol, 6.00 equiv). Yield: $39 \%(115 \mathrm{mg})$ as a white solid. ${ }^{1} \mathrm{H}$ NMR $(400 \mathrm{MHz}, \mathrm{DMSO}): \delta 12.06$ (br s, $1 \mathrm{H}), 7.10(\mathrm{~d}, J=8.0 \mathrm{~Hz}, 2 \mathrm{H})$, $7.03(\mathrm{~d}, J=8.0 \mathrm{~Hz}, 2 \mathrm{H}), 6.18($ br s, $2 \mathrm{H}), 3.90(\mathrm{~s}, 2 \mathrm{H}), 2.23(\mathrm{~s}, 3 \mathrm{H})$, 2.08-2.01 (m, 1H), 1.01-0.94 (m, 2H), 0.94-0.87 (m, 2H) ppm. LC-MS (ESI) $\mathrm{m} / z$ calcd for $\mathrm{C}_{16} \mathrm{H}_{17} \mathrm{~N}_{5} \mathrm{O}[\mathrm{M}+\mathrm{H}]^{+} 296.15$, found 296.13. HPLC: 6.279 min, purity $97 \%$.

2-Amino-5-cyclopropyl-6-(4-fluorobenzyl) [1,2,4]triazolo[1,5-a]pyrimidin-7(4H)-one (20). Compound was synthesized according to general procedure 3 , using the following reagents: 3,5diamino-4H-1,2,4-triazole $5 \mathrm{c}(150 \mathrm{mg}, 1.51 \mathrm{mmol}, 2.00$ equiv), $4 \mathrm{bm}$ (200 mg, $0.756 \mathrm{mmol}, 1.00$ equiv), and BMIM-PF6 (1.00 mL, 4.86 mmol, 6.39 equiv). Yield: $35 \%(79 \mathrm{mg})$ as a white solid. ${ }^{1} \mathrm{H}$ NMR (400 MHz, DMSO): $\delta 12.13(\mathrm{~s}, 1 \mathrm{H}), 7.28$ (dd, $J=9.6,2.4 \mathrm{~Hz}, 2 \mathrm{H})$, $7.07(\mathrm{t}, J=8.8 \mathrm{~Hz}, 2 \mathrm{H}), 6.21(\mathrm{~s} \mathrm{br}, 2 \mathrm{H}), 3.95(\mathrm{~s}, 2 \mathrm{H}), 2.15-2.02(\mathrm{~m}$ $1 \mathrm{H}), \quad 1.05-0.85(\mathrm{~m}, 4 \mathrm{H})$ ppm. LC-MS (ESI) $\mathrm{m} / z$ calcd for $\mathrm{C}_{15} \mathrm{H}_{14} \mathrm{FN}_{5} \mathrm{O}[\mathrm{M}+\mathrm{H}]^{+}$300.13, found 300.2. HPLC: $6.394 \mathrm{~min}$, purity $95 \%$.

2-Amino-6-(4-chlorobenzyl)-5-cyclopropyl[1,2,4]triazolo$[1,5-a]$ pyrimidin-7(4H)-one (21). Compound was synthesized according to general procedure 3 , using the following reagents: 3,5 diamino-4H-1,2,4-triazole $5 \mathrm{c}$ ( $179 \mathrm{mg}, 1.84 \mathrm{mmol}, 2.00$ equiv), $4 \mathrm{bn}$ (258 mg, $0.92 \mathrm{mmol}, 1.00$ equiv), and BMIM-PF6 (1.14 mL, 5.52 mmol, 6.00 equiv). Yield: $33 \%$ (105 mg) as a white solid. ${ }^{1} \mathrm{H}$ NMR (400 MHz, DMSO): $\delta 12.18($ br s, $1 \mathrm{H}), 7.28(\mathrm{~d}, J=8.4 \mathrm{~Hz}, 2 \mathrm{H})$, $7.25(\mathrm{~d}, J=8.4 \mathrm{~Hz}, 2 \mathrm{H}), 6.24(\mathrm{br} \mathrm{s}, 2 \mathrm{H}), 3.94(\mathrm{~s}, 2 \mathrm{H}), 2.10-2.00(\mathrm{~m}$, $1 \mathrm{H}), 1.04-0.94(\mathrm{~m}, 2 \mathrm{H}), 0.93-0.81(\mathrm{~m}, 2 \mathrm{H}) \mathrm{ppm}$. LC-MS (ESI) $m / z$ calcd for $\mathrm{C}_{15} \mathrm{H}_{14} \mathrm{ClN}_{5} \mathrm{O}[\mathrm{M}+\mathrm{H}]^{+} 316.10$, found 316.13. HPLC: 6.393 min, purity $96 \%$.

2-Amino-5-cyclopropyl-6-(4-bromobenzyl) [1,2,4]triazolo$[1,5-a]$ pyrimidin-7 $(4 H)$-one (22). Compound was synthesized according to general procedure 3 , using the following reagents: 3,5diamino-4H-1,2,4-triazole $5 \mathrm{c}$ ( $120 \mathrm{mg}, 1.21 \mathrm{mmol}, 2.00$ equiv), 4bo (200 mg, $0.615 \mathrm{mmol}, 1.00$ equiv), and BMIM-PF6 (1,00 mL, 4.86 mmol, 7.90 equiv). Yield: $21 \%(47 \mathrm{mg})$ as an off-white solid. ${ }^{1} \mathrm{H}$ NMR (400 MHz, DMSO): $\delta 12.15(\mathrm{~s}, 1 \mathrm{H}), 7.42(\mathrm{~d}, J=8.4 \mathrm{~Hz}, 2 \mathrm{H})$, $7.20(\mathrm{~d}, J=8.0 \mathrm{~Hz}, 2 \mathrm{H}), 6.24(\mathrm{br} \mathrm{s}, 2 \mathrm{H}), 3.92(\mathrm{~s}, 2 \mathrm{H}), 2.10-2.00(\mathrm{~m}$, $1 \mathrm{H}), \quad 1.08-0.75(\mathrm{~m}, 4 \mathrm{H})$ ppm. LC-MS (ESI) $\mathrm{m} / z$ calcd for $\mathrm{C}_{15} \mathrm{H}_{14} \mathrm{BrN}_{5} \mathrm{O}[\mathrm{M}+\mathrm{H}]^{+}$360.05, found 360.1. HPLC: $6.474 \mathrm{~min}$, purity $96 \%$.

2-Amino-5-cyclopropyl-6-(4-methoxybenzyl)[1,2,4]triazolo$[1,5-a]$ pyrimidin-7 $(4 H)$-one (23). Compound was synthesized according to general procedure 3 , using the following reagents: $3,5-$ diamino-4H-1,2,4-triazole 5c ( $165 \mathrm{mg}, 1.70 \mathrm{mmol}, 2.00$ equiv), 4bp (235 mg, $0.85 \mathrm{mmol}, 1.00$ equiv), and BMIM-PF6 (1.05 mL, 5.10 mmol, 6.00 equiv). Yield: $41 \%$ (109 $\mathrm{mg})$ as a white solid. ${ }^{1} \mathrm{H}$ NMR (400 MHz, DMSO): $\delta 12.07$ (br s, $1 \mathrm{H}), 7.15(\mathrm{~d}, J=8.4 \mathrm{~Hz}, 2 \mathrm{H})$, $6.80(\mathrm{~d}, J=8.8 \mathrm{~Hz}, 2 \mathrm{H}), 6.19(\mathrm{br} \mathrm{s}, 2 \mathrm{H}), 3.88(\mathrm{~s}, 2 \mathrm{H}), 3.69(\mathrm{~s}, 3 \mathrm{H})$, $2.12-2.01(\mathrm{~m}, 1 \mathrm{H}), 1.04-0.95(\mathrm{~m}, 2 \mathrm{H}), 0.94-0.86(\mathrm{~m}, 2 \mathrm{H}) \mathrm{ppm}$. LC-MS (ESI) $m / z$ calcd for $\mathrm{C}_{16} \mathrm{H}_{17} \mathrm{~N}_{5} \mathrm{O}_{2}[\mathrm{M}+\mathrm{H}]^{+} 312.15$, found 312.07. HPLC: $5.753 \mathrm{~min}$, purity $96 \%$.

2-Amino-6-(3-chlorobenzyl)-5-methyl[1,2,4]triazolo[1,5-a]pyrimidin-7(4H)-one (24). ${ }^{23}$ Compound was synthesized according to general procedure 3 , using the following reagents: 3,5-diamino- $4 \mathrm{H}$ 1,2,4-triazole $5 c$ (94 mg, $0.95 \mathrm{mmol}, 2.00$ equiv), 4aa (120 mg, 0.47 
mmol, 1.00 equiv), and BMIM-PF6 (0.58 mL, $2.82 \mathrm{mmol}, 6.00$ equiv). Yield: $57 \%(77 \mathrm{mg})$ as a white solid. ${ }^{1} \mathrm{H}$ NMR $(400 \mathrm{MHz}$, DMSO): $\delta 12.56(\mathrm{~s}, 1 \mathrm{H}), 7.30-7.21(\mathrm{~m}, 3 \mathrm{H}), 7.17(\mathrm{~d}, J=7.2 \mathrm{~Hz}$, $1 \mathrm{H}), 5.99(\mathrm{~s}, 2 \mathrm{H}), 3.78(\mathrm{~s}, 2 \mathrm{H}), 2.25(\mathrm{~s}, 3 \mathrm{H}) \mathrm{ppm}$. LC-MS (ESI) m/ $z$ calcd for $\mathrm{C}_{13} \mathrm{H}_{12} \mathrm{ClN}_{5} \mathrm{O}[\mathrm{M}+\mathrm{H}]^{+}$290.08, found 290.1. HPLC: 5.709 min, purity $99 \%$.

2-Amino-6-(3-chlorobenzyl)-5-ethyl[1,2,4]triazolo[1,5-a]pyrimidin-7(4H)-one (25). ${ }^{23}$ Compound was synthesized according to general procedure 3 , using the following reagents: 3,5-diamino- $4 \mathrm{H}$ 1,2,4-triazole $5 \mathrm{c}$ ( $141 \mathrm{mg}, 1.43 \mathrm{mmol}, 2.00$ equiv), $4 \mathrm{ca}$ ( $192 \mathrm{mg}, 0.71$ mmol, 1.00 equiv), and BMIM-PF6 $(0.88 \mathrm{~mL}, 4.28 \mathrm{mmol}, 6.00$ equiv). Yield: $21 \%\left(46 \mathrm{mg}\right.$ ) as a white solid. ${ }^{1} \mathrm{H}$ NMR $(500 \mathrm{MHz}$, DMSO): $\delta 12.57(\mathrm{~s}, 1 \mathrm{H}) 7.29-7.51(\mathrm{~m}, 2 \mathrm{H}), 7.22(\mathrm{~d}, J=8.0 \mathrm{~Hz}$, $1 \mathrm{H}), 7.16(\mathrm{~d}, J=7.5 \mathrm{~Hz}, 1 \mathrm{H}), 6.02(\mathrm{~s}, 2 \mathrm{H}), 3.81(\mathrm{~s}, 2 \mathrm{H}), 2.57(\mathrm{q}, J=$ $7.5 \mathrm{~Hz}, 2 \mathrm{H}), 1.05(\mathrm{t}, \mathrm{J}=7.5 \mathrm{~Hz}, 3 \mathrm{H}) \mathrm{ppm}$. LC-MS (ESI) $\mathrm{m} / z$ calcd for $\mathrm{C}_{14} \mathrm{H}_{14} \mathrm{ClN}_{5} \mathrm{O}[\mathrm{M}+\mathrm{H}]^{+}$304.10, found 304.2. HPLC: $6.156 \mathrm{~min}$, purity $95 \%$.

2-Amino-6-(3-chlorobenzyl)-5-propyl[1,2,4]triazolo[1,5-a]pyrimidin-7(4H)-one (26). ${ }^{23}$ Compound was synthesized according to general procedure 3 , using the following reagents: 3,5-diamino- $4 \mathrm{H}$ 1,2,4-triazole 5c (210 mg, $2.12 \mathrm{mmol}, 2.00$ equiv), 4da (300 mg, 1.06 mmol, 1.00 equiv), and BMIM-PF6 ( $1.31 \mathrm{~mL}, 6.36 \mathrm{mmol}, 6.00$ equiv). Yield: $22 \%(76 \mathrm{mg})$ as a white solid. ${ }^{1} \mathrm{H}$ NMR $(400 \mathrm{MHz}$, DMSO): $\delta 12.56(\mathrm{~s}, 1 \mathrm{H}), 7.29-7.20(\mathrm{~m}, 3 \mathrm{H}), 7.16(\mathrm{~d}, J=7.6 \mathrm{~Hz}$, $1 \mathrm{H}), 6.01(\mathrm{~s}, 2 \mathrm{H}), 3.81(\mathrm{~s}, 2 \mathrm{H}), 2.53(\mathrm{t}, J=7.6 \mathrm{~Hz}, 2 \mathrm{H}), 1.45$ (sextet, $J=7.6 \mathrm{~Hz}, 2 \mathrm{H}), 0.85(\mathrm{t}, J=7.2 \mathrm{~Hz}, 3 \mathrm{H}) \mathrm{ppm}$. LC-MS (ESI) $\mathrm{m} / z$ calcd for $\mathrm{C}_{15} \mathrm{H}_{16} \mathrm{ClN}_{5} \mathrm{O}[\mathrm{M}+\mathrm{H}]^{+} 318.11$, found 318.2. HPLC: 6.660 min, purity $99 \%$.

2-Amino-6-(3-chlorobenzyl)-5-isopropyl[1,2,4]triazolo[1,5a]pyrimidin-7(4H)-one (27). ${ }^{23}$ Compound was synthesized according to general procedure 3 , using the following reagents: 3,5-diamino$4 \mathrm{H}-1,2,4$-triazole $5 \mathrm{c}(284 \mathrm{mg}, 2.87 \mathrm{mmol}, 2.00$ equiv), 1ea $(407 \mathrm{mg}$, $1.44 \mathrm{mmol}, 1.00$ equiv), and BMIM-PF6 (1.76 mL, $8.63 \mathrm{mmol}, 6.00$ equiv). Yield: $21 \%(96 \mathrm{mg})$ as a white solid. ${ }^{1} \mathrm{H}$ NMR $(400 \mathrm{MHz}$, DMSO): $\delta 12.33(\mathrm{~s}, 1 \mathrm{H}), 7.28(\mathrm{t}, J=8.0 \mathrm{~Hz}, 1 \mathrm{H}), 7.35(\mathrm{~s}, 1 \mathrm{H}), 7.21$ $(\mathrm{d}, J=8.0 \mathrm{~Hz}, 1 \mathrm{H}), 7.14(\mathrm{~d}, J=7.6 \mathrm{~Hz}, 1 \mathrm{H}), 6.04(\mathrm{~s}, 2 \mathrm{H}) 3.89(\mathrm{~s}$, 2H), 3.18 (septet, J=6.8 Hz, 1H), $1.12(\mathrm{~d}, \mathrm{~J}=6.8 \mathrm{~Hz}, 6 \mathrm{H}) \mathrm{ppm}$. LCMS (ESI) $m / z$ calcd for $\mathrm{C}_{15} \mathrm{H}_{16} \mathrm{ClN}_{5} \mathrm{O}[\mathrm{M}+\mathrm{H}]^{+} 318.11$, found 318.2. HPLC: 6.596 min, purity $99 \%$.

2-Amino-5-butyl-6-(3-chlorobenzyl)[1,2,4]triazolo[1,5-a]pyrimidin-7(4H)-one (28). ${ }^{23}$ Compound was synthesized according to general procedure 3 , using the following reagents: 3,5 -diamino- $4 \mathrm{H}$ 1,2,4-triazole $5 \mathrm{c}$ ( $250 \mathrm{mg}, 1.51 \mathrm{mmol}, 2.14$ equiv), 1 fa $(210 \mathrm{mg}, 0.708$ mmol, 1.00 equiv), and BMIM-PF6 (1.00 mL, $4.86 \mathrm{mmol}, 6.86$ equiv). Yield: $20 \%(47 \mathrm{mg})$ as a white solid. Purity: $98 \% .{ }^{1} \mathrm{H}$ NMR $(400 \mathrm{MHz}, \mathrm{DMSO}) \delta 12.54(\mathrm{~s}, 1 \mathrm{H}), 7.33-7.19(\mathrm{~m}, 3 \mathrm{H}), 7.16(\mathrm{~d}, J=$ $7.3 \mathrm{~Hz}, 1 \mathrm{H}), 6.02(\mathrm{~s}, 2 \mathrm{H}), 3.82(\mathrm{~s}, 2 \mathrm{H}), 2.60-2.50(\mathrm{~m}, 2 \mathrm{H}), 1.45-$ $1.32(\mathrm{~m}, 2 \mathrm{H}), 1.32-1.20(\mathrm{~m}, 2 \mathrm{H}), 0.81(\mathrm{t}, J=7.1 \mathrm{~Hz}, 3 \mathrm{H}) \mathrm{ppm}$. LCMS (ESI) $m / z$ calcd for $\mathrm{C}_{16} \mathrm{H}_{18} \mathrm{ClN}_{5} \mathrm{O}[\mathrm{M}+\mathrm{H}]^{+} 332.13$, found 332.3. HPLC: 7.027 min, purity $98 \%$.

2-Amino-6-(3-chlorobenzyl)-5-(2-ethylbutyl)[1,2,4]triazolo[1,5-a]pyrimidin-7(4H)-one (29). Compound was synthesized according to general procedure 3 , using the following reagents: $3,5-$ diamino-4H-1,2,4-triazole $5 \mathrm{c}(130 \mathrm{mg}, 1.31 \mathrm{mmol}, 2.13$ equiv), 4 ga (200 mg, $0.616 \mathrm{mmol}, 1.00$ equiv), and BMIM-PF6 (1.00 mL, 4.86 mmol, 7.89 equiv). Yield: $9 \%(20 \mathrm{mg})$ as a white solid. ${ }^{1} \mathrm{H}$ NMR (400 MHz, DMSO): $\delta 12.49$ (br s, $1 \mathrm{H}), 7.28(\mathrm{t}, J=7.2 \mathrm{~Hz}, 1 \mathrm{H}), 7.24-$ $7.18(\mathrm{~m}, 2 \mathrm{H}), 7.14(\mathrm{~d}, J=7.2 \mathrm{~Hz}, 1 \mathrm{H}), 5.91(\mathrm{br} \mathrm{s}, 2 \mathrm{H}), 3.82(\mathrm{~s}, 2 \mathrm{H})$, $1.58(\mathrm{~s}, 2 \mathrm{H}), 1.30-1.15(\mathrm{~m}, 5 \mathrm{H}), 0.77(\mathrm{t}, J=6.8 \mathrm{~Hz}, 6 \mathrm{H}) \mathrm{ppm}$. LCMS (ESI) $m / z$ calcd for $\mathrm{C}_{18} \mathrm{H}_{22} \mathrm{ClN}_{5} \mathrm{O}[\mathrm{M}+\mathrm{H}]^{+} 360.16$, found 360.3. HPLC: $7.640 \mathrm{~min}$, purity $97 \%$.

2-Amino-6-(3-chlorobenzyl)-5-pentyl[1,2,4]triazolo[1,5-a]pyrimidin-7(4H)-one (30). Compound was synthesized according to general procedure 3 , using the following reagents: 3,5-diamino- $4 \mathrm{H}$ 1,2,4-triazole 5c (120 mg, $1.21 \mathrm{mmol}, 1.88$ equiv), 4ha $(200 \mathrm{mg}$, $0.643 \mathrm{mmol} ; 1.00$ equiv), and BMIM-PF6 (1.00 mL, $4.86 \mathrm{mmol}, 7.56$ equiv). Yield: $24 \%(52 \mathrm{mg})$ as a white solid. ${ }^{1} \mathrm{H}$ NMR $(400 \mathrm{MHz}$, DMSO): $\delta 12.43($ br s, $1 \mathrm{H}), 7.35-7.10(\mathrm{~m}, 4 \mathrm{H}), 6.02($ br s, $2 \mathrm{H})$, $3.82(\mathrm{~s}, 2 \mathrm{H}), 1.45-1.15(\mathrm{~m}, 6 \mathrm{H}), 0.79(\mathrm{~s}, 3 \mathrm{H}) \mathrm{ppm}$. LC-MS (ESI) $m / z$ calcd for $\mathrm{C}_{17} \mathrm{H}_{20} \mathrm{ClN}_{5} \mathrm{O}[\mathrm{M}+\mathrm{H}]^{+} 346.15$, found 346.2. HPLC: $7.376 \mathrm{~min}$, purity $98 \%$.

2-Amino-6-(3-chlorobenzyl)-5-cyclopentyl[1,2,4]triazolo[1,5-a]pyrimidin-7(4H)-one (31). Compound was synthesized according to general procedure 3 , using the following reagents: 3,5diamino-4H-1,2,4-triazole $5 \mathrm{c}(130 \mathrm{mg}, 1.31 \mathrm{mmol}, 2.00$ equiv), 4ia (200 mg, $0.647 \mathrm{mmol}, 1.00$ equiv), and BMIM-PF6 (1.00 mL, 4.86 mmol, 7.51 equiv). Yield: $38 \%(86 \mathrm{mg})$ as a white solid. ${ }^{1} \mathrm{H}$ NMR (400 MHz, DMSO): $\delta 12.36$ (br s, $1 \mathrm{H}), 7.38-7.07(\mathrm{~m}, 4 \mathrm{H}), 6.07(\mathrm{br}$ $\mathrm{s}, 2 \mathrm{H}), 3.90(\mathrm{~s}, 2 \mathrm{H}), 3.23(\mathrm{~m}, 1 \mathrm{H}), 1.90-1.45(\mathrm{~m}, 8 \mathrm{H}) \mathrm{ppm}$. LC-MS (ESI) $m / z$ calcd for $\mathrm{C}_{17} \mathrm{H}_{18} \mathrm{ClN}_{5} \mathrm{O}[\mathrm{M}+\mathrm{H}]^{+} 344.13$, found 344.1 . HPLC: 7.049 min, purity $99 \%$.

2-Amino-6-(3-chlorobenzyl)-5-hexyl[1,2,4]triazolo[1,5-a]pyrimidin-7(4H)-one (32). Compound was synthesized according to general procedure 3 , using the following reagents: 3,5-diamino- $4 \mathrm{H}$ 1,2,4-triazole $5 \mathrm{c}$ ( $86 \mathrm{mg}, 0.86 \mathrm{mmol}, 2.00$ equiv), $4 \mathrm{ja}$ ( $140 \mathrm{mg}, 0.431$ mmol, 1.00 equiv), and BMIM-PF6 (1.00 mL, $4.86 \mathrm{mmol}, 11.3$ equiv). Yield: $83 \%(128 \mathrm{mg})$ as a white solid. ${ }^{1} \mathrm{H}$ NMR $(400 \mathrm{MHz}$, DMSO): $\delta 12.50(\mathrm{~s}, 1 \mathrm{H}), 7.33-7.19(\mathrm{~m}, 3 \mathrm{H}), 7.15(\mathrm{~d}, J=6.8 \mathrm{~Hz}$, $1 \mathrm{H}), 6.02(\mathrm{~s}, 2 \mathrm{H}), 3.82(\mathrm{~s}, 2 \mathrm{H}), 2.60-2.40(\mathrm{~m}, 2 \mathrm{H}), 1.44-1.32(\mathrm{~m}$, $2 \mathrm{H}), 1.30-1.08(\mathrm{~m}, 6 \mathrm{H}), 0.82(\mathrm{t}, J=6.5 \mathrm{~Hz}, 3 \mathrm{H}) \mathrm{ppm}$. LC-MS (ESI) $\mathrm{m} / z$ calcd for $\mathrm{C}_{18} \mathrm{H}_{22} \mathrm{ClN}_{5} \mathrm{O}[\mathrm{M}+\mathrm{H}]^{+} 360.16$, found 360.3 . HPLC: $7.843 \mathrm{~min}$, purity $97 \%$.

2-Amino-6-(3-chlorobenzyl)-5-heptyl[1,2,4]triazolo[1,5-a]pyrimidin-7(4H)-one (33). Compound was synthesized according to general procedure 3 , using the following reagents: 3,5-diamino- $4 \mathrm{H}$ 1,2,4-triazole $5 \mathrm{c}$ (116 mg, $1.18 \mathrm{mmol}, 2.00$ equiv), 4ka (200 mg, $0.591 \mathrm{mmol}, 1.00$ equiv), and BMIM-PF6 (1.00 mL, $4.86 \mathrm{mmol}, 8.22$ equiv). Yield: $50 \%(108 \mathrm{mg})$ as a white solid. ${ }^{1} \mathrm{H}$ NMR $(400 \mathrm{MHz}$, DMSO): $\delta 12.55(\mathrm{~s}, 1 \mathrm{H}), 7.30-7.19(\mathrm{~m}, 3 \mathrm{H}), 7.15(\mathrm{~d}, J=6.4 \mathrm{~Hz}$, $1 \mathrm{H}), 6.01(\mathrm{~s}, 1 \mathrm{H}), 3.82(\mathrm{~s}, 2 \mathrm{H}), 1.46-1.32(\mathrm{~m}, 2 \mathrm{H}), 1.27-1.10(\mathrm{~m}$, $8 \mathrm{H}), 0.83(\mathrm{t}, J=6.4 \mathrm{~Hz}, 3 \mathrm{H}) \mathrm{ppm}$. LC-MS (ESI) $\mathrm{m} / z$ calcd for $\mathrm{C}_{19} \mathrm{H}_{24} \mathrm{ClN}_{5} \mathrm{O}[\mathrm{M}+\mathrm{H}]^{+}$374.18, found 374.3. HPLC: $8.200 \mathrm{~min}$, purity $98 \%$.

2-Amino-6-(3-chlorobenzyl)-5-phenyl[1,2,4]triazolo[1,5-a]pyrimidin-7(4H)-one (34). Compound was synthesized according to general procedure 3 , using the following reagents: 3,5-diamino- $4 \mathrm{H}$ 1,2,4-triazole 5c (177 mg, $1.79 \mathrm{mmol}, 2.00$ equiv), $41 \mathrm{a}(296 \mathrm{mg}, 0.89$ mmol, 1.00 equiv), and BMIM-PF6 (1.11 mL, $5.36 \mathrm{mmol}, 6.00$ equiv). Yield: $30 \%$ (95 mg) as a white solid. ${ }^{1} \mathrm{H}$ NMR (500 MHz, DMSO): $\delta 12.83(\mathrm{~s}, 1 \mathrm{H}), 7.53-7.47(\mathrm{~m}, 3 \mathrm{H}), 7.42(\mathrm{dd}, J=8.0,1.5$ $\mathrm{Hz}, 2 \mathrm{H}), 7.20(\mathrm{t}, J=8.0 \mathrm{~Hz}, 1 \mathrm{H}), 7.17(\mathrm{~d}, J=7.0 \mathrm{~Hz}, 1 \mathrm{H}), 7.03(\mathrm{~s}$, $1 \mathrm{H}), 6.94(\mathrm{~d}, J=7.0 \mathrm{~Hz}, 1 \mathrm{H}), 6.12(\mathrm{~s}, 2 \mathrm{H}), 3.64(\mathrm{~s}, 2 \mathrm{H}) \mathrm{ppm}$. LCMS (ESI) $m / z$ calcd for $\mathrm{C}_{18} \mathrm{H}_{14} \mathrm{ClN}_{5} \mathrm{O}[\mathrm{M}+\mathrm{H}]^{+} 352.10$, found 352.2. HPLC: $6.946 \mathrm{~min}$, purity $99 \%$.

2-Amino-6-(3-chlorobenzyl)-5-(p-tolyl)[1,2,4]triazolo[1,5-a]pyrimidin-7(4H)-one (35). Compound was synthesized according to general procedure 3 , using the following reagents: 3,5-diamino- $4 \mathrm{H}$ 1,2,4-triazole 5c (181 mg, $1.82 \mathrm{mmol}, 2.00$ equiv), 4ma (314 mg, $0.937 \mathrm{mmol}, 1.00$ equiv), and BMIM-PF6 (1.5 mL, $7.28 \mathrm{mmol}, 7.77$ equiv). Yield: $33 \%(108 \mathrm{mg})$ as a white solid. ${ }^{1} \mathrm{H}$ NMR $(400 \mathrm{MHz}$, DMSO): $\delta 12.80(\mathrm{~s}, 1 \mathrm{H}), 7.33-7.28(\mathrm{~m}, 4 \mathrm{H}), 7.26-7.14(\mathrm{~m}, 2 \mathrm{H})$, $7.05(\mathrm{~s}, 1 \mathrm{H}), 6.96(\mathrm{~d}, J=7.1 \mathrm{~Hz}, 1 \mathrm{H}), 6.11(\mathrm{~s}, 2 \mathrm{H}), 3.64(\mathrm{~s}, 2 \mathrm{H}), 2.36$ (s, 3H) ppm. LC-MS (ESI) $\mathrm{m} / z$ calcd for $\mathrm{C}_{19} \mathrm{H}_{16} \mathrm{ClN}_{5} \mathrm{O}[\mathrm{M}+\mathrm{H}]^{+}$ 366.20, found 366.2. HPLC: $7.342 \mathrm{~min}$, purity $98 \%$.

Procedure for the synthesis of 2-Amino-6-(3-chlorobenzyl)5-phenethyl[1,2,4]triazolo[1,5-a]pyrimidin-7(4H)-one (36). A mixture of $4 \mathrm{na}(213 \mathrm{mg}, 0.57 \mathrm{mmol}, 1.00$ equiv), 3,5-diamino- $4 \mathrm{H}$ 1,2,4-triazole $5 \mathrm{c}$ (116 $\mathrm{mg}, 1.16 \mathrm{mmol}, 2.00$ equiv), and orthophosphoric acid $85 \%(59.6 \mu \mathrm{L}, 0.906 \mathrm{mmol}, 1.58$ equiv) in $\mathrm{EtOH}(1$ $\mathrm{mL}$ ) was stirred for $1 \mathrm{~min}$ at $20^{\circ} \mathrm{C}$ and then heated at $175^{\circ} \mathrm{C}$ under microwave irradiation for $3 \mathrm{~h}$. The reaction mixture was allowed to cool to room temperature, and $\mathrm{CH}_{2} \mathrm{Cl}_{2}(30 \mathrm{~mL})$, water $(10 \mathrm{~mL})$, and aqueous citric acid $(5 \%, 1 \mathrm{~mL})$ were added. The resulting precipitate was stirred for $20 \mathrm{~min}$, filtered, and the residue was washed with hot methanol, collected, and dried in vacuo to afford the title compound. Yield: $22 \%\left(49 \mathrm{mg}\right.$ ) as a white solid. ${ }^{1} \mathrm{H}$ NMR (400 MHz, DMSO): $\delta$ $12.67(\mathrm{~s}, 1 \mathrm{H}), 7.32-7.18(\mathrm{~m}, 6 \mathrm{H}), 7.17-7.10(\mathrm{~m}, 3 \mathrm{H}), 6.06(\mathrm{br} \mathrm{s}$, $2 \mathrm{H}), 3.76(\mathrm{~s}, 2 \mathrm{H}), 2.84-2.78(\mathrm{~m}, 2 \mathrm{H}), 2.70-2.66(\mathrm{~m}, 2 \mathrm{H}) \mathrm{ppm}$. 
LC-MS (ESI) $m / z$ calcd for $\mathrm{C}_{20} \mathrm{H}_{18} \mathrm{ClN}_{5} \mathrm{O}[\mathrm{M}+\mathrm{H}]^{+} 380.13$, found 380.2. HPLC: $7.392 \mathrm{~min}$, purity $97 \%$.

2-Amino-5-cyclopropyl-6-(3,4-dichlorobenzyl) [1,2,4]triazolo[1,5-a]pyrimidin-7(4H)-one (37). ${ }^{23}$ Compound was synthesized according to general procedure 3 , using the following reagents: 3,5-diamino- $4 \mathrm{H}$-1,2,4-triazole $5 \mathrm{c}(157 \mathrm{mg}, 1.58 \mathrm{mmol}, 2.00$ equiv), 4bq ( $250 \mathrm{mg}, 0.79 \mathrm{mmol}, 1.00$ equiv), and BMIM-PF6 (1.3 $\mathrm{mL}, 4.74 \mathrm{mmol}, 6.00$ equiv). Yield: $31 \%(86 \mathrm{mg})$ as a white solid. ${ }^{1} \mathrm{H}$ NMR (400 MHz, DMSO): $\delta 12.26$ (br s, $1 \mathrm{H}), 7.52-7.47$ (m, 2H), $7.22(\mathrm{~d}, J=8.4 \mathrm{~Hz}, 2 \mathrm{H}), 6.26(\mathrm{br} \mathrm{s}, 2 \mathrm{H}), 3.95(\mathrm{~s}, 2 \mathrm{H}), 2.12-2.01(\mathrm{~m}$, $1 \mathrm{H}), 1.01-0.85(\mathrm{~m}, 4 \mathrm{H}) \mathrm{ppm}$. LC-MS (ESI) $\mathrm{m} / z$ calcd for $\mathrm{C}_{15} \mathrm{H}_{13} \mathrm{Cl}_{2} \mathrm{~N}_{5} \mathrm{O}[\mathrm{M}+\mathrm{H}]^{+}$350.06, found 350.1. HPLC: $6.836 \mathrm{~min}$, purity $96 \%$.

2-Amino-6-(3,4-dichlorobenzyl)-5-isopropyl[1,2,4]triazolo$[1,5-a]$ pyrimidin-7(4H)-one (38). Compound was synthesized according to general procedure 3 , using the following reagents: 3,5diamino-4H-1,2,4-triazole $5 \mathrm{c}$ ( $125 \mathrm{mg}, 1.26 \mathrm{mmol}, 2.00$ equiv), 4eq (200 mg, $0.63 \mathrm{mmol}, 1.00$ equiv), and BMIM-PF6 (1.00 mL, 4.86 mmol, 7.71 equiv). Yield: $34 \%(76 \mathrm{mg})$, as a white solid. ${ }^{1} \mathrm{H}$ NMR (400 MHz, DMSO): $\delta 12.23($ br s, $1 \mathrm{H}), 7.54-7.43(\mathrm{~m}, 2 \mathrm{H}), 7.17(\mathrm{~d}$, $J=8.0 \mathrm{~Hz}, 1 \mathrm{H}), 6.09(\mathrm{~s}, 2 \mathrm{H}), 3.88(\mathrm{~s}, 2 \mathrm{H}), 3.22-3.13(\mathrm{~m}, 1 \mathrm{H}), 1.12$ (d, $J=6.4 \mathrm{~Hz}, 6 \mathrm{H}$ ) ppm. LC-MS (ESI) $m / z$ calcd for $\mathrm{C}_{15} \mathrm{H}_{15} \mathrm{Cl}_{2} \mathrm{~N}_{5} \mathrm{O}$ $[\mathrm{M}+\mathrm{H}]^{+}$352.08, found 352.3. HPLC: $7.008 \mathrm{~min}$, purity $97 \%$.

2-Amino-6-(2,3-dichlorobenzyl)-5-isopropyl[1,2,4]triazolo[1,5-a]pyrimidin-7(4H)-one (39). Compound was synthesized according to general procedure 3 , using the following reagents: 3,5diamino-4H-1,2,4-triazole $5 \mathrm{c}(125 \mathrm{mg}, 1.26 \mathrm{mmol}, 2.00$ equiv), 4er (200 mg, $0.630 \mathrm{mmol}, 1.00$ equiv), and BMIM-PF6 (1.00 mL, 4.86 mmol, 7.71 equiv). Yield: $48 \%(106 \mathrm{mg})$ as a white solid. ${ }^{1} \mathrm{H}$ NMR $\left(500 \mathrm{MHz}, \mathrm{DMSO}-d_{6}, 80{ }^{\circ} \mathrm{C}\right): \delta 7.44(\mathrm{dd}, J=7.9,1.5 \mathrm{~Hz}, 1 \mathrm{H}), 7.21$ $(\mathrm{t}, J=7.9 \mathrm{~Hz}, 1 \mathrm{H}), 6.97$ (dd, $J=7.2,1.5 \mathrm{~Hz}, 1 \mathrm{H}), 5.83(\mathrm{~s} \mathrm{br}, 2 \mathrm{H})$, $3.98(\mathrm{~s}, 2 \mathrm{H}), 2.96$ (pentet, $J=6.9 \mathrm{~Hz}, 1 \mathrm{H}), 1.16(\mathrm{~d}, J=6.9 \mathrm{~Hz}, 6 \mathrm{H})$ ppm. ${ }^{13} \mathrm{C}$ NMR (126 MHz, DMSO- $\left.d_{6}\right): \delta 161.8,156.0,155.6,149.7$, $140.1,131.4,130.5,127.7,127.4,126.9,104.5,29.4,28.3,19.6 \mathrm{ppm}$. LC-MS (ESI) $m / z$ calcd for $\mathrm{C}_{15} \mathrm{H}_{15} \mathrm{Cl}_{2} \mathrm{~N}_{5} \mathrm{O}[\mathrm{M}+\mathrm{H}]^{+} 352.08$, found 352.2. HPLC: 7.060 min, purity $97 \%$.

2-Amino-6-(2,5-dichlorobenzyl)-5-isopropyl[1,2,4]triazolo[1,5-a]pyrimidin-7(4H)-one (40). Compound was synthesized according to general procedure 3 , using the following reagents: 3,5diamino-4H-1,2,4-triazole 5c ( $125 \mathrm{mg}, 1.26 \mathrm{mmol}, 2.00$ equiv), 4es (200 mg, $0.630 \mathrm{mmol}, 1.00$ equiv), and BMIM-PF6 ( $1.00 \mathrm{~mL}, 4.86$ mmol, 7.71 equiv). Yield: $24 \%(54 \mathrm{mg})$ as a white solid. ${ }^{1} \mathrm{H}$ NMR (400 MHz, DMSO): $\delta 12.41$ (br s, $1 \mathrm{H}), 7.70-7.42(\mathrm{~m}, 1 \mathrm{H}), 7.40-$ $7.19(\mathrm{~m}, 1 \mathrm{H}), 7.16-6.85(\mathrm{~m}, 1 \mathrm{H}), 6.08(\mathrm{br} \mathrm{s}, 2 \mathrm{H}), 3.88(\mathrm{~s}, 2 \mathrm{H})$, 3.01-2.83 (m, 1H), $1.14(\mathrm{~s}, 6 \mathrm{H}) \mathrm{ppm}$. LC-MS (ESI) $\mathrm{m} / z$ calcd for $\mathrm{C}_{15} \mathrm{H}_{15} \mathrm{Cl}_{2} \mathrm{~N}_{5} \mathrm{O}[\mathrm{M}+\mathrm{H}]^{+}$352.08, found 352.2. HPLC: $6.938 \mathrm{~min}$, purity $96 \%$.

2-Amino-6-(3,5-dichlorobenzyl)-5-isopropyl[1,2,4]triazolo[1,5-a]pyrimidin-7(4H)-one (41). Compound was synthesized according to general procedure 3 , using the following reagents: 3,5diamino-4H-1,2,4-triazole 5c ( $96 \mathrm{mg}, 0.97 \mathrm{mmol}, 2$ equiv), 4et (153 $\mathrm{mg}, 0.48 \mathrm{mmol}, 1.00$ equiv), and BMIM-PF6 (1.00 mL, $4.86 \mathrm{mmol}$, 10 equiv). Yield: $18 \%(31 \mathrm{mg})$ as a white solid. ${ }^{1} \mathrm{H}$ NMR $(400 \mathrm{MHz}$, DMSO): $\delta 12.33(\mathrm{~s}, 1 \mathrm{H}), 7.41(\mathrm{~s}, 1 \mathrm{H}), 7.26(\mathrm{~s}, 2 \mathrm{H}), 6.07$ (br s, $2 \mathrm{H})$, $3.89(\mathrm{~s}, 2 \mathrm{H}), 1.13(\mathrm{~s}, 6 \mathrm{H}) \mathrm{ppm}$. LC-MS (ESI) $\mathrm{m} / z$ calcd for $\mathrm{C}_{15} \mathrm{H}_{15} \mathrm{Cl}_{2} \mathrm{~N}_{5} \mathrm{O}[\mathrm{M}+\mathrm{H}]^{+}$352.08, found 352.1. HPLC: $7.103 \mathrm{~min}$, purity $98 \%$.

2-Amino-6-(3,5-dibromobenzyl)-5-isopropyl[1,2,4]triazolo[1,5-a]pyrimidin $7(4 H)$-one (42). Compound was synthesized according to general procedure 3 , using the following reagents: 3,5diamino-4H-1,2,4-triazole $5 \mathrm{c}$ ( $97 \mathrm{mg}, 0.98 \mathrm{mmol}, 2.00$ equiv), 4eu (200 mg, $0.49 \mathrm{mmol}, 1.00$ equiv), and BMIM-PF6 (1.00 mL, 4.86 mmol, 9.91 equiv). Yield: $7 \%(14 \mathrm{mg})$ as a white solid. ${ }^{1} \mathrm{H}$ NMR (400 $\mathrm{MHz}, \mathrm{DMSO}$ ): $\delta 12.33$ (br s, $1 \mathrm{H}), 7.63(\mathrm{~s}, 1 \mathrm{H}), 7.42$ (s, 2H), 6.07 (br s, 2H), $3.88(\mathrm{~s}, 2 \mathrm{H}), 1.13(\mathrm{~s}, 6 \mathrm{H}) \mathrm{ppm}$. LC-MS (ESI) $\mathrm{m} / z$ calcd for $\mathrm{C}_{15} \mathrm{H}_{15} \mathrm{Br}_{2} \mathrm{~N}_{5} \mathrm{O}[\mathrm{M}+\mathrm{H}]^{+}$439.97, found 440.1. HPLC: $7.337 \mathrm{~min}$, purity $98 \%$.

2-Amino-6-(3-bromo-4-chloro-benzyl)-5-isopropyl[1,2,4]triazolo[1,5-a]pyrimidin-7(4H)-one (43). Compound was synthesized according to general procedure 3 , using the following reagents:
3,5-diamino-4H-1,2,4-triazole $5 \mathrm{c}$ ( $109 \mathrm{mg}, 1.10 \mathrm{mmol}, 2.00$ equiv), $4 \mathrm{ev}$ (200 mg, $0.553 \mathrm{mmol}, 1.00$ equiv), and BMIM-PF6 (1.00 mL, $4.86 \mathrm{mmol}, 8.83$ equiv). Yield: $24 \%(53 \mathrm{mg})$ as a white solid. ${ }^{1} \mathrm{H}$ NMR (400 MHz, DMSO): $\delta 7.60(\mathrm{~d}, J=2.0 \mathrm{~Hz}, 1 \mathrm{H}), 7.49(\mathrm{~d}, J=8.0$ $\mathrm{Hz}, 1 \mathrm{H}), 7.21(\mathrm{dd}, J=8.0,2.0 \mathrm{~Hz}, 1 \mathrm{H}), 6.08(\mathrm{br} \mathrm{s}, 2 \mathrm{H}), 3.87(\mathrm{~s}, 2 \mathrm{H})$, $3.22-3.11(\mathrm{~m}, 1 \mathrm{H}), 1.12(\mathrm{~d}, J=7.2 \mathrm{~Hz}, 6 \mathrm{H}) \mathrm{ppm}$. LC-MS (ESI) $\mathrm{m} /$ $z$ calcd for $\mathrm{C}_{15} \mathrm{H}_{15} \mathrm{BrClN}_{5} \mathrm{O}[\mathrm{M}+\mathrm{H}]^{+}$396.02, found 396.1. HPLC: $7.080 \mathrm{~min}$, purity $98 \%$.

Chemicals and Reagents. The human recombinant chemokines CCL2 and CCL3 were purchased from PeproTech (Rocky Hill, NJ). TAK-779 was obtained from NIH AIDS reagent program (Germantown, MD, catalogue number 4983). All triazolopyrimidinone derivatives were synthesized in-house. Guanosine $5^{\prime}-O-[\gamma$-thio $]$ triphosphate $\left(\left[{ }^{35} \mathrm{~S}[\mathrm{GTP} \gamma \mathrm{S})\right.\right.$ (specific activity $1250 \mathrm{Ci} / \mathrm{mmol}$ ) was purchased from PerkinElmer (Waltham, MA), while $\left[{ }^{3} \mathrm{H}\right]$-CCR2-RA$[R]$ (specific activity $59.6 \mathrm{Ci} \mathrm{mmol}^{-1}$ ) was custom-labeled by Vitrax (Placentia, CA). Bovine serum albumin was purchased from SigmaAldrich (St. Louis, MO). Bicinchoninic acid (BCA) and Pierce BCA protein assay kit were purchased from Pierce Biotechnology (Thermo Scientific, Rockford, IL). Tango U2OS cells stably expressing human CCR2b (U2OS-CCR2) or human CCR5 (U2OS-CCR5) were purchased from Invitrogen (Carlsbad, CA). All other chemicals were obtained from standard commercial sources.

Cell Culture. Both U2OS-CCR2b and U2OS-CCR5 cells were cultured in McCoy's 5A medium supplemented with $10 \%(\mathrm{v} / \mathrm{v})$ fetal calf serum, $2 \mathrm{mM}$ glutamine, $0.1 \mathrm{mM}$ nonessential amino acids, 25 $\mathrm{mM}$ HEPES, $1 \mathrm{mM}$ sodium pyruvate, $200 \mathrm{IU} / \mathrm{mL}$ penicillin, $200 \mu \mathrm{g} /$ $\mathrm{mL}$ streptomycin, $100 \mu \mathrm{g} / \mathrm{mL} \mathrm{G} 418,40-50 \mu \mathrm{g} / \mathrm{mL}$ hygromycin, and $125 \mu \mathrm{g} / \mathrm{mL}$ zeocin. Cells were grown until $80 \%$ confluence and cultured twice-weekly on 10 or $15 \mathrm{~cm} \varnothing$ plates by trypsinization. Dialyzed fetal calf serum was used when culturing cells for functional assays or as a last step before membrane preparation.

Membrane Preparation. Membranes from U2OS-CCR2 or U2OS-CCR5 cells were prepared as previously described for CCR2. ${ }^{20}$ Briefly, U2OS-CCR2 or U2OS-CCR5 cells were scraped from confluent $15 \mathrm{~cm} \varnothing$ plates using phosphate buffered saline (PBS) and subsequently centrifuged at $3000 \mathrm{rpm}$ for $5 \mathrm{~min}$. Pellets were then resuspended in ice-cold Tris buffer $(50 \mathrm{mM}$ Tris- $\mathrm{HCl}, 5 \mathrm{mM} \mathrm{MgCl}$, $\mathrm{pH}$ 7.4) before homogenization with an Ultra Turrax homogenizer (IKA-Werke GmbH \& Co. KG, Staufen, Germany). Membranes and cytosolic contents were separated using an Optima LE-80 K ultracentrifuge (Beckman Coulter, Inc., Fullerton, CA) at 31000 rpm for $20 \mathrm{~min}$ at $4{ }^{\circ} \mathrm{C}$. After a second cycle of homogenization and centrifugation, the final pellet was resuspended and homogenized in ice-cold Tris buffer, aliquoted, and stored at $-80{ }^{\circ} \mathrm{C}$. Finally, membrane protein concentrations were determined using a BCA protein determination assay, as described by the manufacturer (Pierce BCA protein assay kit). ${ }^{5}$

$\left[{ }^{3} \mathrm{H}\right]-C C R 2-R A-[R]$ Binding Assays. For $\left[{ }^{3} \mathrm{H}\right]-C C R 2-R A-[R]$ displacement assays, U2OS-CCR2b membrane homogenates (15$20 \mu \mathrm{g}$ of total protein) were incubated with $\sim 6 \mathrm{nM}\left[{ }^{3} \mathrm{H}\right]$-CCR2-RA$[R]$ and at least 6 increasing concentrations of competing ligand in a final volume of $100 \mu \mathrm{L}$ of assay buffer ( $50 \mathrm{mM}$ Tris-HCl, $5 \mathrm{mM}$ $\mathrm{MgCl}_{2}, 0.1 \%$ CHAPS, pH 7.4). Ligands were diluted to the desired concentration with an HP D300 digital dispenser (Tecan, Giessen, The Netherlands). Total radioligand binding did not exceed $10 \%$ of the amount added to prevent ligand depletion, and nonspecific binding was determined using $10 \mu \mathrm{M}$ CCR2-RA- $[R]$. After $2 \mathrm{~h}$ at 25 ${ }^{\circ} \mathrm{C}$, incubation was terminated by rapid filtration through a 96 -well GF/B filterplate on a PerkinElmer FilterMate harvester, using ice-cold wash buffer $(50 \mathrm{mM}$ Tris- $\mathrm{HCl}$ buffer supplemented with $5 \mathrm{mM}$ $\mathrm{MgCl}_{2}$ and $0.05 \%$ CHAPS, $\mathrm{pH}$ 7.4). Filters were washed 10 times with ice-cold wash buffer and subsequently dried at $55{ }^{\circ} \mathrm{C}$ for $30 \mathrm{~min}$. After addition of $25 \mu \mathrm{L}$ of Microscint scintillation cocktail (PerkinElmer), the filter-bound radioactivity was measured by scintillation spectrometry using the P-E 2450 Microbeta $^{2}$ counter (PerkinElmer).

Tango $\beta$-Arrestin Recruitment Assay. $\beta$-Arrestin recruitment was measured using the Tango CCR2-bla or CCR5-bla U2OS cellbased assay (Invitrogen) according to the manufacturer's protocol. 
Briefly, U2OS-CCR2b or U2OS-CCR5 cells were grown until approximately $80 \%$ confluence and detached by trypsinization. Cells were recovered by centrifugation at $1000 \mathrm{rpm}$ for $5 \mathrm{~min}$, resuspended in assay medium (FreeStyle Expression Medium, Invitrogen) to a density of 10000 cells per well and seeded into black-wall, clearbottom, 384-well assay plates (Corning). For agonist assays, cells were exposed to increasing concentrations of CCL2 or CCL3 for CCR2 or CCR5, respectively, for $16 \mathrm{~h}$ at $37^{\circ} \mathrm{C}$ and $5 \% \mathrm{CO}_{2}$. For antagonist assays, compounds were first diluted in assay medium containing a final DMSO concentration of $0.5 \%$ or lower. Cells were then preincubated with either $1 \mu \mathrm{M}$ (for single-point inhibition experiments) or increasing concentrations of antagonist for $30 \mathrm{~min}$ at room temperature, before a 16 hour co-incubation with an $\mathrm{EC}_{80}$ concentration of CCL2 $(5 \mathrm{nM})$ or CCL3 $(14 \mathrm{nM})$ at $37{ }^{\circ} \mathrm{C}$ and $5 \% \mathrm{CO}_{2}$. After $16 \mathrm{~h}$ cells were loaded in the dark with $8 \mu \mathrm{L}$ of LiveBLAzer-FRET B/G substrate (Invitrogen) and incubated for $2 \mathrm{~h}$ at room temperature. Finally, fluorescence emission at 460 and 535 $\mathrm{nm}$ was measured in an EnVision multilabel plate reader (PerkinElmer) after excitation at $400 \mathrm{~nm}$. The ratio of emission at 460 and $535 \mathrm{~nm}$ was calculated for each well.

$\left.{ }^{35} \mathrm{~S}\right]$ GTP $\gamma \mathrm{S}$ Binding Assay. To determine the mechanism of inhibition $\left[{ }^{35} \mathrm{~S}\right] \mathrm{GTP} \gamma \mathrm{S}$ binding assays were performed. In CCR2 the $\left[{ }^{35} \mathrm{~S}\right] \mathrm{GTP} \gamma \mathrm{S}$ binding assay was performed as previously described. ${ }^{19,20}$ In the case of CCR5, an amount of $10 \mu \mathrm{g}$ of U2OS-CCR5 membranes with $0.25 \mathrm{mg} / \mathrm{mL}$ saponin was preincubated with $5 \mu \mathrm{M}$ GDP, increasing concentrations of CCL3, and three different antagonist concentrations for $30 \mathrm{~min}$ at $25^{\circ} \mathrm{C}$. All dilutions were made in assay buffer containing $50 \mathrm{mM}$ Tris- $\mathrm{HCl}$ ( $\mathrm{pH} 7.4), 10 \mathrm{mM} \mathrm{MgCl}, 10 \mathrm{mM}$ $\mathrm{NaCl}, 1 \mathrm{mM}$ EDTA, and $0.05 \%$ BSA. $\left[{ }^{35} \mathrm{~S}\right] \mathrm{GTP} \gamma \mathrm{S}(0.3 \mathrm{nM})$ was added, and the mixture was co-incubated for an additional $90 \mathrm{~min}$ at $25{ }^{\circ} \mathrm{C}$ before harvesting. Incubation was stopped by dilution with icecold $50 \mathrm{mM}$ Tris- $\mathrm{HCl}$ buffer with $5 \mathrm{mM} \mathrm{MgCl}$. Separation of bound and unbound radioligand was performed by rapid filtration through a 96-well GF/B filter plate as described in " $\left[{ }^{3} \mathrm{H}\right]$-CCR2-RA- $[R]$ Binding Assays".

Data Analysis. All experiments were analyzed using nonlinear regression curve fitting program Prism 7 (GraphPad, San Diego, CA). $\mathrm{EC}_{50}, \mathrm{EC}_{80}, E_{\max }$ and $\mathrm{IC}_{50}$ values from functional assays were obtained by nonlinear regression analysis. All values obtained are the mean \pm SEM of at least three separate experiments performed in duplicate, unless stated otherwise. For radioligand binding assays, $K_{\mathrm{i}}$ values were determined using the Cheng-Prussoff equation using a $K_{\mathrm{D}}$ of $6.3 \mathrm{nM}$ for the radioligand. ${ }^{19}$

Computational Modeling. The inactive crystal structure of hCCR2b with BMS-681 and CCR2-RA- $[R]$ (PDB code 5T1A) ${ }^{15}$ was used as the basis for docking compounds $8,39,40$, and 43. Docking was performed in the Schrodinger suite, ${ }^{54}$ as previously described for the docking of CCR2-RA- $[R] .{ }^{19}$ Before docking, the CCR2b crystal structure was prepared by replacing the residues between L $226^{5 \times 62}$ and $\mathrm{R} 240^{6 \times 32}$, which correspond to the M2 muscarinic acetylcholine receptor, with the CCR2b sequence using prime ${ }^{55-57}$ and CCR5 as template (PDB code 4MBS). ${ }^{35}$ Induced fit docking, with a substructure restraint on the right-hand phenyl ( $R^{1}$, SMARTS: "clccccl") was used to dock compound 43 in the hCCR $2 b$ model. ${ }^{58,59}$ Compounds 8,39 , and 40 were docked using regular docking (Glide-SP) on the basis of the model of compound 43 . Figures $4 \mathrm{a}, 4 \mathrm{~b}$, and S4 were rendered using PyMOL. ${ }^{60}$

\section{ASSOCIATED CONTENT}

\section{S Supporting Information}

The Supporting Information is available free of charge at https://pubs.acs.org/doi/10.1021/acs.jmedchem.9b00742.

Characterization of ligands in a U2OS-CCR5 $\beta$-arrestinrecruitment assay (Figure $S 1$ ); correlation between $\log P$ $(\mathrm{cLogP})$ and affinity $\left(\mathrm{p} K_{\mathrm{i}}\right)$ values in CCR2 (Figure S2); characterization of compounds 39 and 43 as potential inverse agonists in hCCR2 (Figure S3); docking of compounds 8, 39, 40, and 43 (Figure S4); list of intermediate compounds $4 \mathbf{a a}-\mathbf{n a}, \mathbf{4 b b}-\mathbf{b q}, \mathbf{4 e q}-\mathbf{e v}$ (Table S1); functional activity of TAK-779 and CCR2$\mathrm{RA}-[R]$ in hCCR5, using a CCL3-induced $\beta$-arrestin recruitment assay (Table S2); and functional activity of compounds 8,39 , and 43 in hCCR2, using a CCL2induced $\beta$-arrestin recruitment assay (Table S3) (PDF) Molecular formula strings and some data (CSV)

Model of CCR2b (PDB)

Model of compound 8 (PDB)

Model of compound 39 (PDB)

Model of compound 40 (PDB)

Model of compound 43 (PDB)

\section{AUTHOR INFORMATION}

\section{Corresponding Author}

*Phone: +31 (0) 71527 4651. E-mail: ijzerman@lacdr. leidenuniv.nl.

ORCID $\odot$

Adriaan P. IJzerman: 0000-0002-1182-2259

Author Contributions

The manuscript was written through contributions of all authors. All authors have given approval to the final version of the manuscript.

Notes

The authors declare no competing financial interest.

\section{ACKNOWLEDGMENTS}

The following reagent was obtained through the NIH AIDS Reagent Program, Division of AIDS, NIAID, NIH: TAK-779.

\section{ABBREVIATIONS USED}

CCR2, CC chemokine receptor 2; CCR5, CC chemokine receptor 5; GPCR, G-protein-coupled receptor; SAR, structure-affinity/activity relationship; U2OS, human osteosarcoma cell; IP, inositol phosphate; $\left[{ }^{35} \mathrm{~S}\right] \mathrm{GTP} \gamma \mathrm{S}$, guanosine $5^{\prime}-O-\left(3-\left[{ }^{35} \mathrm{~S}\right]\right.$ thio $)$ triphosphate; BCA, bicinchoninic acid; cryo$\mathrm{EM}$, cryoelectron microscopy; NEAA, nonessential amino acid; PBS, phosphate buffered saline; SEM, standard error of the mean

\section{REFERENCES}

(1) Bachelerie, F.; Ben-Baruch, A.; Burkhardt, A. M.; Combadiere, C.; Farber, J. M.; Graham, G. J.; Horuk, R.; Sparre-Ulrich, A. H.; Locati, M.; Luster, A. D.; Mantovani, A.; Matsushima, K.; Murphy, P. M.; Nibbs, R.; Nomiyama, H.; Power, C. A.; Proudfoot, A. E.; Rosenkilde, M. M.; Rot, A.; Sozzani, S.; Thelen, M.; Yoshie, O.; Zlotnik, A. International union of basic and clinical pharmacology. LXXXIX. Update on the extended family of chemokine receptors and introducing a new nomenclature for atypical chemokine receptors. Pharmacol. Rev. 2014, 66 (1), 1-79.

(2) Lopez-Cotarelo, P.; Gomez-Moreira, C.; Criado-Garcia, O.; Sanchez, L.; Rodriguez-Fernandez, J. L. Beyond chemoattraction: multifunctionality of chemokine receptors in leukocytes. Trends Immunol. 2017, 38 (12), 927-941.

(3) Schall, T. J.; Proudfoot, A. E. Overcoming hurdles in developing successful drugs targeting chemokine receptors. Nat. Rev. Immunol. 2011, 11 (5), 355-363.

(4) Zweemer, A. J.; Toraskar, J.; Heitman, L. H.; IJzerman, A. P. Bias in chemokine receptor signalling. Trends Immunol. 2014, 35 (6), $243-252$

(5) Koelink, P. J.; Overbeek, S. A.; Braber, S.; de Kruijf, P.; Folkerts, G.; Smit, M. J.; Kraneveld, A. D. Targeting chemokine receptors in 
chronic inflammatory diseases: an extensive review. Pharmacol. Ther. 2012, 133 (1), 1-18.

(6) White, G. E.; Iqbal, A. J.; Greaves, D. R. CC chemokine receptors and chronic inflammation-therapeutic opportunities and pharmacological challenges. Pharmacol. Rev. 2013, 65 (1), 47-89.

(7) Woollard, S. M.; Kanmogne, G. D. Maraviroc: a review of its use in HIV infection and beyond. Drug Des., Dev. Ther. 2015, 9, 54475468.

(8) Horuk, R. Chemokine receptor antagonists: overcoming developmental hurdles. Nat. Rev. Drug Discovery 2009, 8 (1), 23-33.

(9) Horuk, R. Promiscuous drugs as therapeutics for chemokine receptors. Expert Rev. Mol. Med. 2009, 11, e1.

(10) Friedman, S. L.; Ratziu, V.; Harrison, S. A.; Abdelmalek, M. F.; Aithal, G. P.; Caballeria, J.; Francque, S.; Farrell, G.; Kowdley, K. V.; Craxi, A.; Simon, K.; Fischer, L.; Melchor-Khan, L.; Vest, J.; Wiens, B. L.; Vig, P.; Seyedkazemi, S.; Goodman, Z.; Wong, V. W.-S.; Loomba, R.; Tacke, F.; Sanyal, A.; Lefebvre, E. A randomized, placebocontrolled trial of cenicriviroc for treatment of nonalcoholic steatohepatitis with fibrosis. Hepatology 2018, 67 (5), 1754-1767.

(11) Zhao, Q. Dual targeting of CCR2 and CCR5: therapeutic potential for immunologic and cardiovascular diseases. J. Leukocyte Biol. 2010, 88 (1), 41-55.

(12) Fantuzzi, L.; Tagliamonte, M.; Gauzzi, M. C.; Lopalco, L. Dual CCR5/CCR2 targeting: opportunities for the cure of complex disorders. Cell. Mol. Life Sci. 2019, DOI: 10.1007/s00018-01903255-6.

(13) Junker, A.; Kokornaczyk, A. K.; Strunz, A. K.; Wünsch, B. Selective and dual targeting of CCR2 and CCR5 receptors: a current overview. In Chemokines: Chemokines and Their Receptors in Drug Discovery; Tschammer, N., Ed.; Springer International Publishing: Cham, Switzerland, 2015; Vol. 14, pp 187-241.

(14) Kothandan, G.; Gadhe, C. G.; Cho, S. J. Structural insights from binding poses of CCR2 and CCR5 with clinically important antagonists: a combined in silico study. PLoS One 2012, 7 (3), e32864.

(15) Zheng, Y.; Qin, L.; Ortiz Zacarías, N. V.; de Vries, H.; Han, G. W.; Gustavsson, M.; Dabros, M.; Zhao, C.; Cherney, R. J.; Carter, P.; Stamos, D.; Abagyan, R.; Cherezov, V.; Stevens, R. C.; IJzerman, A. P.; Heitman, L. H.; Tebben, A.; Kufareva, I.; Handel, T. M. Structure of CC chemokine receptor 2 with orthosteric and allosteric antagonists. Nature 2016, 540 (7633), 458-461.

(16) Oswald, C.; Rappas, M.; Kean, J.; Dore, A. S.; Errey, J. C.; Bennett, K.; Deflorian, F.; Christopher, J. A.; Jazayeri, A.; Mason, J. S.; Congreve, M.; Cooke, R. M.; Marshall, F. H. Intracellular allosteric antagonism of the CCR9 receptor. Nature 2016, 540 (7633), 462465 .

(17) Turner, M. D.; Nedjai, B.; Hurst, T.; Pennington, D. J. Cytokines and chemokines: at the crossroads of cell signalling and inflammatory disease. Biochim. Biophys. Acta, Mol. Cell Res. 2014, 1843 (11), 2563-2582.

(18) Ortiz Zacarias, N. V.; Lenselink, E. B.; IJzerman, A. P.; Handel, T. M.; Heitman, L. H. Intracellular receptor modulation: novel approach to target GPCRs. Trends Pharmacol. Sci. 2018, 39 (6), 547559.

(19) Ortiz Zacarías, N. V.; van Veldhoven, J. P. D.; Portner, L.; van Spronsen, E.; Ullo, S.; Veenhuizen, M.; van der Velden, W. J. C.; Zweemer, A. J. M.; Kreekel, R. M.; Oenema, K.; Lenselink, E. B.; Heitman, L. H.; IJzerman, A. P. Pyrrolone derivatives as intracellular allosteric modulators for chemokine receptors: selective and dualtargeting inhibitors of CC chemokine receptors 1 and 2. J. Med. Chem. 2018, 61 (20), 9146-9161.

(20) Zweemer, A. J.; Nederpelt, I.; Vrieling, H.; Hafith, S.; Doornbos, M. L.; de Vries, H.; Abt, J.; Gross, R.; Stamos, D.; Saunders, J.; Smit, M. J.; IJzerman, A. P.; Heitman, L. H. Multiple binding sites for small-molecule antagonists at the CC chemokine receptor 2. Mol. Pharmacol. 2013, 84 (4), 551-561.

(21) Zweemer, A. J.; Bunnik, J.; Veenhuizen, M.; Miraglia, F.; Lenselink, E. B.; Vilums, M.; de Vries, H.; Gibert, A.; Thiele, S.; Rosenkilde, M. M.; IJzerman, A. P.; Heitman, L. H. Discovery and mapping of an intracellular antagonist binding site at the chemokine receptor CCR2. Mol. Pharmacol. 2014, 86 (4), 358-368.

(22) Andrews, G.; Jones, C.; Wreggett, K. A. An intracellular allosteric site for a specific class of antagonists of the CC chemokine G protein-coupled receptors CCR4 and CCR5. Mol. Pharmacol. 2008, 73 (3), 855-867.

(23) Bengtsson, B. A.; Blackaby, W.; Cumming, J.; Faull, A. W.; Larsson, J.; Nash, I. A.; Oldham, K.; Pape, A. 4H-[1, 2, 4] Triazolo [5, 1-b] Pyrimidin-7-one Derivatives As CCR2b Receptor Antagonists. Patent WO 2011/114148 A1, 2011.

(24) Boyd, J. W.; Meo, P.; Higginbottom, M.; Simpson, I.; Mountford, D.; Savory, E. D. 7-Hydroxy-Pyrazolo [1,5-a] Pyrimidine Compounds And Their Use As CCR2 Receptor Antagonists. Patent WO 2012/041817 A1, 2012.

(25) Isberg, V.; de Graaf, C.; Bortolato, A.; Cherezov, V.; Katritch, V.; Marshall, F. H.; Mordalski, S.; Pin, J.-P.; Stevens, R. C.; Vriend, G.; Gloriam, D. E. Generic GPCR residue numbers - aligning topology maps while minding the gaps. Trends Pharmacol. Sci. 2015, $36(1), 22-31$.

(26) Baba, M.; Nishimura, O.; Kanzaki, N.; Okamoto, M.; Sawada, H.; Iizawa, Y.; Shiraishi, M.; Aramaki, Y.; Okonogi, K.; Ogawa, Y.; Meguro, K.; Fujino, M. A small-molecule, nonpeptide CCR5 antagonist with highly potent and selective anti-HIV-1 activity. Proc. Natl. Acad. Sci. U. S. A. 1999, 96 (10), 5698-5703.

(27) Thum, S.; Kokornaczyk, A. K.; Seki, T.; De Maria, M.; Ortiz Zacarias, N. V.; de Vries, H.; Weiss, C.; Koch, M.; Schepmann, D.; Kitamura, M.; Tschammer, N.; Heitman, L. H.; Junker, A.; Wunsch, B. Synthesis and biological evaluation of chemokine receptor ligands with 2-benzazepine scaffold. Eur. J. Med. Chem. 2017, 135, 401-413.

(28) Corbisier, J.; Gales, C.; Huszagh, A.; Parmentier, M.; Springael, J. Y. Biased signaling at chemokine receptors. J. Biol. Chem. 2015, 290 (15), 9542-9554.

(29) Prinz, H. Hill coefficients, dose-response curves and allosteric mechanisms. J. Chem. Biol. 2010, 3 (1), 37-44.

(30) Zou, D.; Zhai, H.-X.; Eckman, J.; Higgins, P.; Gillard, M.; Knerr, L.; Carre, S.; Pasau, P.; Collart, P.; Grassi, J. Novel, acidic CCR2 receptor antagonists: from hit to lead. Lett. Drug. Des. Discovery 2007, 4 (3), 185-191.

(31) Csermely, P.; Ágoston, V.; Pongor, S. The efficiency of multitarget drugs: the network approach might help drug design. Trends Pharmacol. Sci. 2005, 26 (4), 178-182.

(32) Morphy, J. R. The Challenges of Multi-Target Lead Optimization. In Designing Multi-Target Drugs; Morphy, J. R., Harris, C. J., Eds.; The Royal Society of Chemistry, 2012; pp 141154.

(33) Buntinx, M.; Hermans, B.; Goossens, J.; Moechars, D.; Gilissen, R. A.; Doyon, J.; Boeckx, S.; Coesemans, E.; Van Lommen, G.; Van Wauwe, J. P. Pharmacological profile of JNJ-27141491 [(S)-3-[3, 4difluorophenyl)-propyl]-5-isoxazol-5-yl-2-thioxo-2, 3-dihydro-1H-imidazole-4-carboxyl acid methyl ester], as a noncompetitive and orally active antagonist of the human chemokine receptor CCR2. J. Pharmacol. Exp. Ther. 2008, 327 (1), 1-9.

(34) Vauquelin, G.; Szczuka, A. Kinetic versus allosteric mechanisms to explain insurmountable antagonism and delayed ligand dissociation. Neurochem. Int. 2007, 51 (5), 254-260.

(35) Tan, Q.; Zhu, Y.; Li, J.; Chen, Z.; Han, G. W.; Kufareva, I.; Li, T.; Ma, L.; Fenalti, G.; Li, J.; Zhang, W.; Xie, X.; Yang, H.; Jiang, H.; Cherezov, V.; Liu, H.; Stevens, R. C.; Zhao, Q.; Wu, B. Structure of the CCR5 chemokine receptor-HIV entry inhibitor maraviroc complex. Science 2013, 341 (6152), 1387-1390.

(36) Wilcken, R.; Zimmermann, M. O.; Lange, A.; Joerger, A. C.; Boeckler, F. M. Principles and applications of halogen bonding in medicinal chemistry and chemical biology. J. Med. Chem. 2013, 56 (4), 1363-1388.

(37) Salchow, K.; Bond, M. E.; Evans, S. C.; Press, N. J.; Charlton, S. J.; Hunt, P. A.; Bradley, M. E. A common intracellular allosteric binding site for antagonists of the CXCR2 receptor. Br. J. Pharmacol. 2010, 159 (7), 1429-1439. 
(38) Nicholls, D. J.; Tomkinson, N. P.; Wiley, K. E.; Brammall, A.; Bowers, L.; Grahames, C.; Gaw, A.; Meghani, P.; Shelton, P.; Wright, T. J.; Mallinder, P. R. Identification of a putative intracellular allosteric antagonist binding-site in the CXC chemokine receptors 1 and 2. Mol. Pharmacol. 2008, 74 (5), 1193-1202.

(39) Draper-Joyce, C. J.; Khoshouei, M.; Thal, D. M.; Liang, Y.-L.; Nguyen, A. T. N.; Furness, S. G. B.; Venugopal, H.; Baltos, J.-A.; Plitzko, J. M.; Danev, R.; Baumeister, W.; May, L. T.; Wootten, D.; Sexton, P. M.; Glukhova, A.; Christopoulos, A. Structure of the adenosine-bound human adenosine A1 receptor-Gi complex. Nature 2018, 558 (7711), 559-563.

(40) Koehl, A.; Hu, H.; Maeda, S.; Zhang, Y.; Qu, Q.; Paggi, J. M.; Latorraca, N. R.; Hilger, D.; Dawson, R.; Matile, H.; Schertler, G. F. X.; Granier, S.; Weis, W. I.; Dror, R. O.; Manglik, A.; Skiniotis, G.; Kobilka, B. K. Structure of the $\mu$-opioid receptor-Gi protein complex. Nature 2018, 558 (7711), 547-552.

(41) Kang, Y.; Kuybeda, O.; de Waal, P. W.; Mukherjee, S.; Van Eps, N.; Dutka, P.; Zhou, X. E.; Bartesaghi, A.; Erramilli, S.; Morizumi, T.; Gu, X.; Yin, Y.; Liu, P.; Jiang, Y.; Meng, X.; Zhao, G.; Melcher, K.; Ernst, O. P.; Kossiakoff, A. A.; Subramaniam, S.; Xu, H. E. Cryo-EM structure of human rhodopsin bound to an inhibitory $G$ protein. Nature 2018, 558 (7711), 553-558.

(42) Kang, Y.; Zhou, X. E.; Gao, X.; He, Y.; Liu, W.; Ishchenko, A.; Barty, A.; White, T. A.; Yefanov, O.; Han, G. W.; Xu, Q.; de Waal, P. W.; Ke, J.; Tan, M. H.; Zhang, C.; Moeller, A.; West, G. M.; Pascal, B. D.; Van Eps, N.; Caro, L. N.; Vishnivetskiy, S. A.; Lee, R. J.; SuinoPowell, K. M.; Gu, X.; Pal, K.; Ma, J.; Zhi, X.; Boutet, S.; Williams, G. J.; Messerschmidt, M.; Gati, C.; Zatsepin, N. A.; Wang, D.; James, D.; Basu, S.; Roy-Chowdhury, S.; Conrad, C. E.; Coe, J.; Liu, H.; Lisova, S.; Kupitz, C.; Grotjohann, I.; Fromme, R.; Jiang, Y.; Tan, M.; Yang, H.; Li, J.; Wang, M.; Zheng, Z.; Li, D.; Howe, N.; Zhao, Y.; Standfuss, J.; Diederichs, K.; Dong, Y.; Potter, C. S.; Carragher, B.; Caffrey, M.; Jiang, H.; Chapman, H. N.; Spence, J. C.; Fromme, P.; Weierstall, U.; Ernst, O. P.; Katritch, V.; Gurevich, V. V.; Griffin, P. R.; Hubbell, W. L.; Stevens, R. C.; Cherezov, V.; Melcher, K.; Xu, H. E. Crystal structure of rhodopsin bound to arrestin by femtosecond $\mathrm{X}$-ray laser. Nature 2015, 523 (7562), 561-567.

(43) Ramsay, R. R.; Popovic-Nikolic, M. R.; Nikolic, K.; Uliassi, E.; Bolognesi, M. L. A perspective on multi-target drug discovery and design for complex diseases. Clin Transl. Med. 2018, 7 (1), 3.

(44) Lagorce, D.; Douguet, D.; Miteva, M. A.; Villoutreix, B. O. Computational analysis of calculated physicochemical and ADMET properties of protein-protein interaction inhibitors. Sci. Rep. 2017, 7, 46277.

(45) Lagorce, D.; Sperandio, O.; Baell, J. B.; Miteva, M. A.; Villoutreix, B. O. FAF-Drugs3: a web server for compound property calculation and chemical library design. Nucleic Acids Res. 2015, 43 (W1), W200-W207.

(46) Baell, J. B.; Holloway, G. A. New substructure filters for removal of pan assay interference compounds (PAINS) from screening libraries and for their exclusion in bioassays. J. Med. Chem. 2010, 53 (7), 2719-2740.

(47) Lager, E.; Nilsson, J.; Østergaard Nielsen, E.; Nielsen, M.; Liljefors, T.; Sterner, O. Affinity of 3-acyl substituted 4-quinolones at the benzodiazepine site of GABAA receptors. Bioorg. Med. Chem. 2008, 16 (14), 6936-6948.

(48) Liu, Y.; Zhang, Q.; Chen, L. H.; Yang, H.; Lu, W.; Xie, X.; Nan, F. J. Design and synthesis of 2-alkylpyrimidine-4,6-diol and 6alkylpyridine-2,4-diol as potent GPR84 agonists. ACS Med. Chem. Lett. 2016, 7 (6), 579-583.

(49) Bowman, R. K.; Johnson, J. S. Nickel-catalyzed rearrangement of 1-acyl-2-vinylcyclopropanes. A mild synthesis of substituted dihydrofurans. Org. Lett. 2006, 8 (4), 573-576.

(50) Doni, E.; Mondal, B.; O'Sullivan, S.; Tuttle, T.; Murphy, J. A. Overturning established chemoselectivities: selective reduction of arenes over malonates and cyanoacetates by photoactivated organic electron donors. J. Am. Chem. Soc. 2013, 135 (30), 10934-10937.
(51) Amupitan, J. A.; Beddoes, R. L.; Mills, O. S.; Sutherland, J. K. 3Methylcyclohex-2-enone derivatives as initiators of cyclisation. Part 4. Some bicyclisations. J. Chem. Soc., Perkin Trans. 1 1983, 0, 759-763.

(52) Sun, X.; Tymianski, M.; Garman, D. Agents And Methods For Treating Ischemic And Other Diseases. Patent WO 2012/174488 A2, 2012.

(53) Smith, P. K.; Krohn, R. I.; Hermanson, G. T.; Mallia, A. K.; Gartner, F. H.; Provenzano, M. D.; Fujimoto, E. K.; Goeke, N. M.; Olson, B. J.; Klenk, D. C. Measurement of protein using bicinchoninic acid. Anal. Biochem. 1985, 150 (1), 76-85.

(54) Maestro, release 2017-1; Schrödinger, LLC: New York, 2017.

(55) Prime, release 2017-1; Schrödinger, LLC: New York, 2017.

(56) Jacobson, M. P.; Friesner, R. A.; Xiang, Z.; Honig, B. On the role of the crystal environment in determining protein side-chain conformations. J. Mol. Biol. 2002, 320 (3), 597-608.

(57) Jacobson, M. P.; Pincus, D. L.; Rapp, C. S.; Day, T. J.; Honig, B.; Shaw, D. E.; Friesner, R. A. A hierarchical approach to all-atom protein loop prediction. Proteins: Struct., Funct., Genet. 2004, 55 (2), $351-367$.

(58) Glide Release 2017-1; Schrödinger Suite Prime 2017-1 Induced Fit Docking Protocol; Schrödinger, LLC: New York, 2017.

(59) Sherman, W.; Day, T.; Jacobson, M. P.; Friesner, R. A.; Farid, R. Novel procedure for modeling ligand/receptor induced fit effects. J. Med. Chem. 2006, 49 (2), 534-553.

(60) The PyMOL Molecular Graphics System, version 1.8; Schrödinger, LLC: New York, 2015. 